Kroon, D., Zachos, J.C., and Richter, C. (Eds.)

Proceedings of the Ocean Drilling Program, Scientific Results Volume 208

\section{LeG 208 Synthesis: Cenozoic Climate CyCles and ExCuRsions ${ }^{1}$}

\author{
Dick Kroon, ${ }^{2}$ James C. Zachos, ${ }^{3}$ and Leg 208 Scientific Party ${ }^{4}$
}

${ }^{1}$ Kroon, D., Zachos, J.C., and Leg 208 Scientific Party, 2007. Leg 208 synthesis: Cenozoic climate cycles and excursions. In Kroon, D., Zachos, J.C., and Richter, C. (Eds.), Proc. ODP, Sci. Results, 208: College Station, TX (Ocean Drilling Program), 1-55. doi:10.2973/odp.proc.sr.208.201.2007 ${ }^{2}$ Faculty of Earth Sciences, Vrije Universiteit, De Boelelaan 1085, HV 1081 Amsterdam, The Netherlands. ${ }^{3}$ Earth and Planetary Sciences Department, University of California, Santa Cruz, Santa Cruz CA 95064, USA. jzachos@es.ucsc.edu ${ }^{4}$ Scientific Party addresses.

Initial receipt: 1 September 2006 Acceptance: 28 February 2007

Web publication: 16 April 2007 of the PETM on calcareous algae, (5) resolving the full magnitude of the 


\section{KROON ET AL.}

carbonate compensation depth shift as well as its timing relative to the onset of Antarctic glaciation in the earliest Oligocene, (6) coupling the middle Miocene high abundances of biserial planktonic foraminifers to changes in regional ocean circulation, (7) constraining the timing of initiation and intensification of North Atlantic Deep Water formation in the Oligocene, (8) increasing the resolution of the Li isotope record for the Neogene, and (9) increasing the resolution of the seawater Sr isotope record for the upper Paleocene and lower Eocene.

\section{INTRODUCTION}

The Paleogene was a climatically dynamic period. Various climate proxies reveal a complex history of warming and cooling, characterized by periods of both gradual and rapid change (Miller et al., 1987; Miller and Katz, 1987; Stott et al., 1990; Zachos et al., 1994, 2001). Major events include a 1-m.y.-long global warming trend that began in the late Paleocene and climaxed in the early Eocene in a 1- to 2-m.y.-long climatic optimum (early Eocene Climatic Optimum [EECO]) and a 12m.y.-long stepped cooling trend that began in the early middle Eocene and culminated in the earliest Oligocene with the appearance of continental-scale ice sheets (Hambrey et al., 1991; Zachos et al., 1992). One of the more prominent events is a transient but extreme greenhouse interval known as the Paleocene/Eocene Thermal Maximum (PETM) at $\sim 55.0 \mathrm{Ma}$. Major changes in ocean chemistry, as inferred from carbon isotope anomalies, and changes in the distribution and preservation patterns of terrigenous and biogenic sediments on the seafloor (e.g., Bralower et al., 1995; Kennett and Stott, 1991; Robert and Kennett, 1997) characterize the PETM. In addition, distinct shifts in the distribution of key groups of fauna and flora occurred in the oceans and on land (e.g., Kelly et al., 1998; Koch et al., 1992, 1995; Thomas and Shackleton, 1996; Thomas, 1998; Wing, 1998). Another notable event is the earliest Oligocene Glacial Maximum (EOGM, or Oi-1), a brief but extreme glacial interval that occurred at $\sim 33.4 \mathrm{Ma}$ and marks the transition to permanent glacial conditions on Antarctica (e.g., Miller et al., 1987, 1991; Zachos et al., 1996; Coxall et al., 2005). This event, like the PETM, caused large-scale perturbations in ocean chemistry and paleoecology (Barrera and Huber, 1991, 1993; Salamy and Zachos, 1999; Thomas and Gooday, 1996; Thunell and Corliss, 1986). Multiple hypotheses exist to explain the large-scale, long-term changes in Paleogene climate, although none have yet gained universal acceptance. In general, among many factors, the role of ocean gateways (continental geography) and greenhouse gas levels are considered key variables. Theoretical models invoke either the absence of a circum-Antarctic current or higher greenhouse levels or some combination of both to account for the EECO (Barron, 1985; Bice et al., 2000; Sloan and Barron, 1992; Sloan and Rea, 1996; Sloan et al., 1992, 1995). Similarly, Oligocene glaciation has been attributed to both the initiation of the Antarctic Circumpolar Current (ACC) and a reduction in greenhouse gas levels (e.g., Kennett and Shackleton, 1976; Mikolajewicz et al., 1993; Oglesby, 1991; Raymo et al., 1990; Rind and Chandler, 1991; DeConto and Pollard, 2003). Some of the more abrupt transient excursions are more likely to have been forced by rapid changes in greenhouse gas levels because they occur over short timescales (e.g., $10^{3}-10^{4} \mathrm{yr}$ ) and, most importantly, are accompanied by geochemical and isotopic anomalies sugges-

tive of major perturbations in the carbon and sulfur cycles (Dickens et 
al., 1995, 1997; Paytan et al., 1998; Pearson and Palmer, 2000; Schmitz et al., 1997; Stott et al., 1990; Zachos et al., 1993).

Further progress in characterizing Paleogene oceanography and climate history, particularly the transient events and rapid shifts, was slowed by the lack of high-quality, high-resolution, multicored sequences. Most sites cored prior to Leg 198 suffer from poor recovery and drilling disturbance, and few were multicored or drilled as part of depth transects. The few exceptions are sites recovered during recent Ocean Drilling Program (ODP) legs including Sites 865, 999, 1001, 1051, and Bass River core hole in New Jersey (Bralower et al., 1995, 1997; Miller et al., 1998; Norris and Röhl, 1999; Röhl et al., 2000, 2001, 2003). High-resolution records produced from these sites have yielded a wealth of exciting, important evidence of climate change to be more fully explored with additional data. The ODP extreme climate advisory panel (Program Planning Group [PPG]) recognized the dearth of highresolution records across climate transients, and the panel formulated new questions concerning extreme climates (Kroon et al., 2000) and potential drilling targets, among which was the Walvis Ridge area. Leg 208 was designed specifically to address this deficiency with a major goal of developing the high-fidelity records necessary to characterize shortterm events, including the changes in ocean chemistry and circulation and biota that theoretically should have accompanied these climatic extremes. Walvis Ridge, located in the eastern South Atlantic Ocean (Fig. F1), was one of the few known locations where previous drilling recovered the PETM and EOGM over a broad depth range. The ridge was the target of drilling by Deep Sea Drilling Project (DSDP) Leg 74, which occupied Sites 525-529 on the northern flank of the ridge at water depths between 2.5 and $4.2 \mathrm{~km}$ (Moore, Rabinowitz, et al., 1984). Paleogene pelagic sediments characterized by moderate sedimentation rates ( 6-15 m/m.y.) and good magnetic stratigraphy were recovered at each site. However, because of poor recovery $(\sim 50 \%-75 \%)$ and coring disturbance, especially with the rotary core barrel in unlithified sediments, only short segments of the sequences were recovered fully intact and none of the sequences were double cored. Technical problems combined with the lack of high-resolution shipboard core logs limited highresolution cyclostratigraphic investigations to a few short segments of the Cretaceous/Paleogene $(\mathrm{K} / \mathrm{Pg})$ boundary interval (Herbert and D'Hondt, 1990). Nevertheless, subsequent shore-based studies of lowresolution samples collected from these cores were instrumental in adding to our understanding of long-term Maastrichtian and Paleogene paleoceanography of the South Atlantic Ocean (e.g., calcite compensation depth [CCD], carbon isotope stratigraphy, and deep-sea temperature/ice volume) (e.g., Moore, Rabinowitz, et al., 1984; Hsü, Labrecque, et al., 1984; Shackleton, 1987). Nearly complete PETM intervals were recovered at the shallowest and deepest Sites 525 and 527, respectively. Stable isotope analysis of foraminifers recovered from these sites helped constrain the magnitude of the deep Atlantic biogeochemical and environmental changes during this event (Thomas et al., 1999; Thomas and Shackleton, 1996). At the remaining sites, the PETM was not recovered because of core gaps.

During the winter of 2000, a seismic survey of southeastern Walvis Ridge was carried out by the Meteor (Cruise M49/1; Speiss et al., 2003) (Fig. F2). The survey extended coverage of the Leg 74 sites to the north and northeast, where more continuous and slightly thicker sediment sequences were discovered. The higher-fidelity multichannel seismic (MCS) data generated during the survey allowed identification of sev-
F1. Bathymetry of Walvis Ridge and South African margin, p. 31.

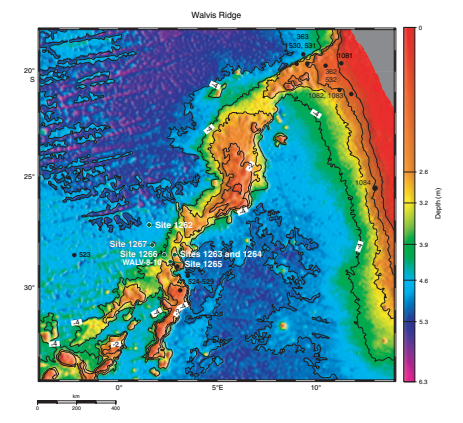

F2. Study area of Leg 208, p. 32.

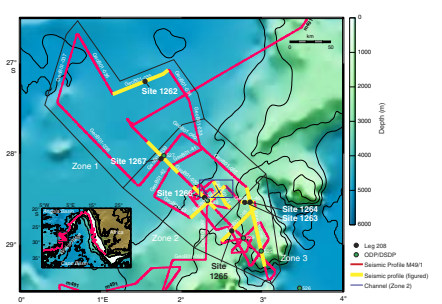




\section{KROON ET AL.}

eral areas where the PETM and other critical intervals could be recovered by advanced piston corer/extended core barrel (APC/XCB) drilling.

Utilizing data from Leg 74 and the new high-resolution MCS profiles of Meteor Cruise M49/1 (Spiess et al., 2003), Leg 208 successfully recovered fully intact, stratigraphically continuous sections of upper Cretaceous and Cenozoic strata at six sites on Walvis Ridge over a depth range of $2.2 \mathrm{~km}$ (Fig. F3), sufficient to constrain depth-dependent changes in the chemistry of deep and intermediate waters. Furthermore, offset drilling in multiple holes at each site allowed $100 \%$ recovery of sequences that were only partially recovered during Leg 74 . Finally, recent advances in data acquisition and cyclostratigraphy enabled high-precision correlation and dating of these sediments and the assembly of composite sections.

\section{Scientific Objectives}

The scientific objectives for Leg 208 are detailed in the Leg 208 Initial Reports volume (Zachos, Kroon, Blum, et al., 2004). The major objectives include the following:

1. Characterize the timing and magnitude of late Paleocene and early Eocene hyperthermal events and associated depth-dependent changes in bottom water temperatures and carbonate chemistry; this includes developing detailed records across the Paleocene/Eocene boundary in order to test the methane hydrate dissociation hypothesis (e.g., Dickens et al., 1995, 1997).

2. Characterize middle Eocene to early Oligocene changes in the regional climate and ocean carbonate chemistry; this includes the early Oligocene Oi-1 glaciation which is associated with a major deepening of the CCD (e.g., Coxall et al., 2005).

3. Develop high-fidelity records of the biotic recovery from the Cretaceous/Paleogene mass extinction with a focus on the rates of foraminifer and calcareous algal speciation and associated changes in biogenic sediment accumulation rates (e.g., D'Hondt et al., 1998).

4. Reconstruct Cenozoic patterns of regional deepwater circulation and chemical gradients utilizing new tracers of water mass distribution (e.g., Thomas et al., 2003).

5. Develop the first high-resolution record of regional Neogene paleoceanography.

6. Develop the first orbitally tuned chronology for the entire Paleocene and lower Eocene.

\section{SYNTHESIS OF PRIMARY FINDINGS}

The sediments recovered during Leg 208 have shed new light on the nature of short-term paleoceanographic events of the last 70 m.y., while also improving our understanding of the general long-term trends as established by earlier cruises. Because of the exceptional core recovery in multiple holes and high-resolution core logging, we were able to resolve the complete spectrum of lithologic variability down to the centimeter scale, including orbitally paced oscillations. As a consequence, Leg 208, with the depth transect approach, was also able to establish the character of both the long- and short-term changes in sediment deposition in the vertical dimension, a constraint that is essential to understanding
F3. Bathymetry of Walvis Ridge, p. 33.

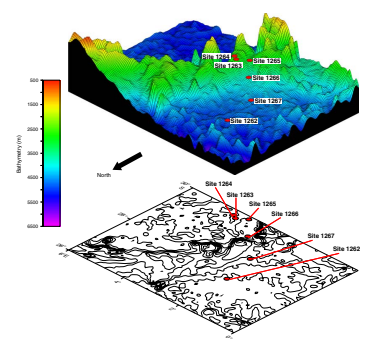


both the causes and consequences of paleoceanographic change. In the following section, we summarize the major findings of this leg to date, focusing primarily on those contributions that are novel or represent a significant improvement upon previous investigations.

\section{Seismic Stratigraphy}

Seismic profiles collected during the site survey cruise were used along with Leg 208 downhole logging and stratigraphic data to develop a three-dimensional reconstruction of sediment distribution on the northeastern flank of Walvis Ridge (Bartels et al., this volume). The multifrequency seismic data were collected using three seismic sources, two generator-injector (GI) guns $(0.4 \mathrm{~L} ; 100-500 \mathrm{~Hz}$ and $1.7 \mathrm{~L} ; 30-200$ $\mathrm{Hz})$ and one water gun $(0.16 \mathrm{~L} ; 200-1600 \mathrm{~Hz})$, in a quasi simultaneous mode in order to obtain the highest possible penetration and resolution of subsurface structures. Figure $\mathbf{F} 4$ shows a comparison between the GI gun data (spectrum 100-500 Hz) and the higher-resolution water gun data (spectrum 200-1600 Hz). Both data sets show the same seismic profile (GeoB01-035) crossing Site 1262. For comparison both profiles are plotted at the same scale. The images principally show the same sediment features in the vicinity of Site 1262 (i.e., parallel to subparallel layering of undisturbed pelagic sediments, a transparent, irregularly shaped body representing a debris flow or slump deposit within the uppermost $100 \mathrm{~ms}$, and a sharp boundary at $6.45 \mathrm{~s}$ two-way traveltime representing the Eocene/Oligocene boundary). Closer examination, however, shows differences between these two data sets in terms of seismic facies. The water gun data show three distinct reflectors or reflector packages of sediments with higher amplitude beneath the sharp boundary at $6.45 \mathrm{~ms}$. In contrast, the GI gun data suggest a gradual transition of physical properties. These sharp interfaces identified in the water gun data represent the Elmo horizon and the PETM and late Paleocene biotic event horizons (Röhl et al., 2004; Petrizzo, 2005), which are characterized by a density contrast of $10 \%$ in comparison to the Eocene and Paleocene sediments. This capability to image sediment layers on a meter to submeter scale was used to identify and correlate critical Cenozoic horizons in all of the Leg 208 cores.

Synthetic seismograms constructed using gamma ray attenuation (GRA) density data from downhole logs along with the shipboard stratigraphic data were used to identify, correlate, and date prominent seismic reflectors. The prominent reflectors all appear to correlate with major event horizons. Gridding of these reflectors or horizons was used to develop a paleoseafloor model that simulates sediment accumulation over the entire seismic grid for the last 65 m.y. (Bartels et al., this volume). This includes the response of sediment accumulation to changes in sediment fluxes in response to various processes such as scouring by bottom water currents. For example, the model shows evidence of a distinct change in bottom water current activity in the southeast sector of the study area between $28^{\circ}$ and $30^{\circ} \mathrm{S}$. Clearly visible is the development of a channel structure across Walvis Ridge, which is likely related to transport of North Atlantic Deep Water (NADW) and Antarctic Bottom Water between the Angola and Cape Basins (Fig. F5). Development of this channel indicates that the current strength increased toward the end of the middle Miocene, a phenomenon that is most likely related to key tectonic and climatic events during that period (e.g., Antarctic ice sheet expansion and closure of the Central American Seaway) (Nisancioglu et al., 2003).
F4. Seismic profile crossing Site 1262, p. 34.

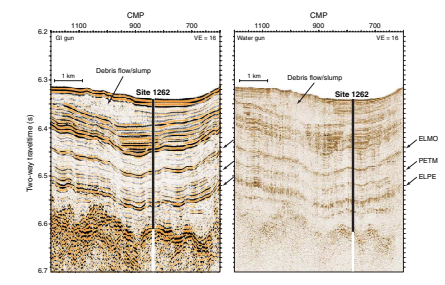

F5. Channel that might represent a path for bottom waters between the Cape and Angola Basins, p. 35.

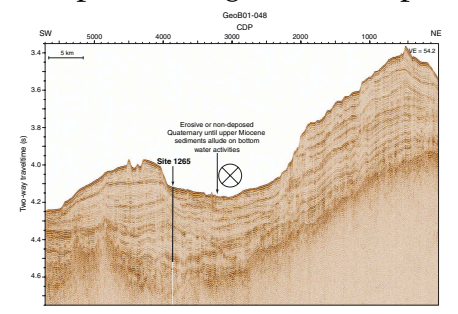




\section{Chronostratigraphy}

The chronostratigraphy of the Leg 208 cores is based on bio-, magneto-, and cyclostratigraphic data. The biostratigraphic work carried out shipboard is reported in the Leg 208 Initial Reports volume (Zachos, Kroon, Blum, et al., 2004). Postcruise refinement of the biostratigraphy is still not completed and thus will not be discussed here.

\section{Magnetostratigraphy}

The soft, weakly magnetized carbonate sediments recovered during Leg 208 frequently produced erratic or seemingly biased directional records, at least in part resulting from coring-related deformation (Bowles, this volume). As a result, shipboard magnetostratigraphic interpretations were difficult or impossible to make over many intervals. Postcruise analysis of discrete samples allowed minor revision of several Paleocene to Upper Cretaceous reversal boundaries but unfortunately did little to refine most of the magnetostratigraphy.

Despite difficulty with the data, several polarity sequences were identifiable, including most of the major boundaries in the Pliocene-Pleistocene, an upper Miocene through Oligocene sequence at Sites 1265 and 1266, and an excellent Paleocene through Upper Cretaceous sequence at Sites 1262 and 1267. Although the inclination records from the Pliocene-Pleistocene are not very clean at most sites, we were frequently able to identify major reversal boundaries. However, assignment to a particular boundary was often aided in this interval by biostratigraphic datums or cyclostratigraphy. Of particular note, Chron $\mathrm{C} 2 \mathrm{n}$, close to the Pliocene/Pleistocene boundary, was identified at all sites except Site 1263. Sites 1265 and 1266 were combined to produce an interpretable upper Miocene through Oligocene sequence. In particular, this includes the excellent expression of Chron C6Cn at Site 1265 across the Oligocene/Miocene $(\mathrm{O} / \mathrm{M})$ boundary. This chron consists of three very distinctive short normal events which, combined with the biostratigraphic data and cyclostratigraphy, should allow refinement of the timescale across the $\mathrm{O} / \mathrm{M}$ boundary. The Eocene was generally not well resolved at any of the sites, but an excellent Paleocene to Upper Cretaceous polarity sequence was recovered at Sites 1262 and 1267 (Fig. F6). At these two sites, the Paleocene cores were recovered either by APC or XCB systems in relatively indurated sediments with a higher clay content, which contributed to a lower degree of deformation over this interval. Identification of the upper and lower boundaries of Chron $\mathrm{C} 24 \mathrm{r}$ is important for constraining the position of the Paleocene/ Eocene $(\mathrm{P} / \mathrm{E})$ boundary within this chron. Whereas the lower boundary was identified shipboard, discrete sample analysis allowed placement of the upper boundary of Chron C24r at Sites 1262 and 1267; this constitutes a significant revision to the shipboard magnetostratigraphy at Site 1262. All remaining Paleocene and Upper Cretaceous reversal boundaries were identified at Sites 1262 and 1267, most to within $\sim 10-30 \mathrm{~cm}$.

\section{Cycle Stratigraphy and Orbital Rhythms}

Cyclic variations are present in core logging and core scanning data throughout the Maastrichtian-Holocene section at all sites. These variations are expressed by lithologic changes at a decimeter to meter scale. Cyclic variability was used during the cruise to correlate between parallel holes and to define a composite section for each site. At that time
F6. Magnetostratigraphy for Paleocene and upper Cretaceous, p. 36.

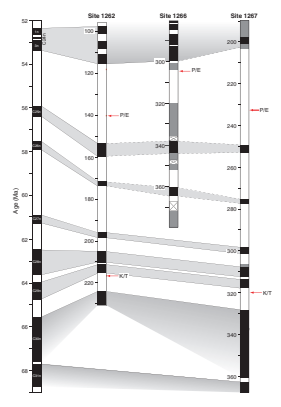


300 characteristic features (peaks or troughs) in magnetic susceptibility were identified and used to correlate between Leg 208 sites (Zachos, Kroon, Blum, et al., 2004). These tie points were dated using the age models of the individual sites. By adopting the average age of each tie point, a refined age model was constructed for the complete Leg 208 74-m.y. record. The distinct record of cyclic alternations in sediment physical properties provides high potential for refining the Neogene astronomical timescale and developing an astronomically tuned timescale of the Paleogene as far back as the Late Cretaceous (Westerhold et al., submitted [N1]). Detailed investigation of the sedimentary cycles and their relation to orbital forcing is an important objective of both already accomplished and ongoing postcruise studies. A definite tuning of the middle Eocene and older timescale faces fundamental issues because the precision of the orbital solutions (Laskar et al, 2004; Varadi et al., 2003) is limited, and there are also relatively large uncertainties in radiometric age constraints. However, a floating tuning and timescale may still be developed. Laskar et al. (2004) recommended that for construction of an astronomically calibrated timescale in the Paleogene only the very stable 405-k.y.-long eccentricity period should be utilized. Using filtering of various high-resolution core logs, including magnetic susceptibility and Fe intensity from X-ray diffraction (XRF), it was possible to identify primary cycles associated with eccentricity, both the 405and 100-k.y. cycles. Within those cycles, the precession cycles could be easily identified and counted (Fig. F7) (e.g., Röhl et al., 2003, 2004; Westerhold et al., in press, submitted [N1]). Given the stability of the 405-k.y. eccentricity cycle, it was possible to obtain a best fit and thus derive numerical ages for the magnetochron boundaries and early Eocene warming events (Fig. F8) (Westerhold et al., in press, submitted [N1]; Röhl et al., 2006).

\section{Critical Events}

A major achievement of Leg 208 was the recovery of continuous undisturbed cores spanning several critical intervals or events. All events were recovered from at least two sites, and at least three of the early Cenozoic events were recovered at five sites. The composite sections along with the pronounced lithologic cycles allow each event to be observed in the context of orbitally paced oscillations in climate and ocean chemistry. The most prominent are the $\mathrm{P} / \mathrm{E}$ and $\mathrm{K} / \mathrm{Pg}$ boundaries, characterized by relatively rapid and extreme change. The other events, although less extreme, show characteristics that indicate brief extremes in climate and/or ocean carbonate chemistry. This includes the midPaleocene biotic event at 58.2 Ma (close to the lowermost occurrence of Heliolithus kleinpellii) (Bralower et al., 2002; Röhl et al., 2004; Petrizzo, 2005), the EOGM at $33.5 \mathrm{Ma}$, the early Oligocene Braarudosphaera layers at 28.5-30 Ma, and the early Miocene Bolivina acme of biserial foraminifers at $18 \mathrm{Ma}$. In addition, several previously unrecognized events, characterized by clay layers similar to the $\mathrm{P} / \mathrm{E}$ boundary but of a smaller scale, were identified in the upper Paleocene and lower Eocene of all sites (Zachos, Kroon, Blum, et al., 2004; Lourens et al., 2005; Röhl et al., 2005). The most distinct of these smaller events are two clay layers in the lower Eocene referred to as the Elmo and X events (Lourens et al., 2005; Röhl et al., 2005) events. The Elmo event occurs in uppermost Chron C24r, close to the uppermost occurrence of Discoaster multiradiatus. The assertion that these dissolution layers are linked to global events, rather than regional, is based on their presence in other ocean
F7. Cycle counting using $\mathrm{a}^{*}$ and Fe intensity data, p. 37.

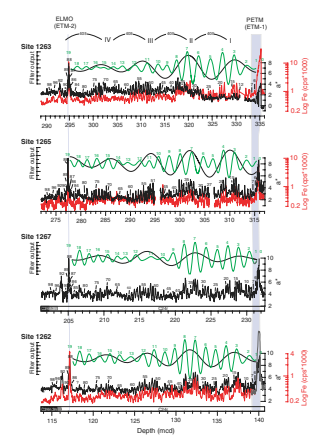

F8. Cycle counting timescale vs. present astronomical solutions for orbital eccentricity, p. 38.

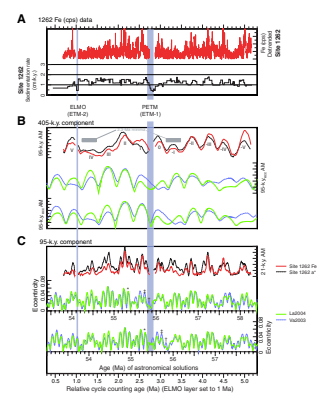




\section{KROON ET AL.}

basins, primarily the Pacific, where they are documented in cores recovered from Shatsky Rise (Bralower, Premoli Silva, Malone, et al., 2002). The documentation of such events is of importance, as their occurrence was predicted on the basis of, for example, anomalous excursions in benthic foraminiferal assemblages (Thomas et al., 2000).

\section{Cretaceous/Paleogene Boundary}

The K/Pg boundary mass extinction reset the state of the global ecosystem. Marine K/Pg boundary sections thus provide an ideal opportunity for testing the recovery of global environment to biological disaster induced by a meteorite impact. Reduced surface ocean carbonate and organic matter production at the $\mathrm{K} / \mathrm{Pg}$ boundary must have led to changes in chemical properties of the ocean and sedimentation patterns. The biogeochemical changes and associated sedimentation include (1) a drastic decrease in deep-sea carbonate sedimentation (Zachos and Arthur, 1986; D'Hondt and Keller, 1991), (2) a rapid decrease in export production, which should have led to decreased pelagic to benthic carbon isotopic gradients (Hsü et al., 1982; Stott and Kennett, 1989; Zachos et al., 1989; D'Hondt et al., 1998), and (3) migration of the lysocline or CCD. Note, however, that models evocating a collapse of primary productivity and/or the biotic pump are in disagreement with the lack of extinction of deep-sea benthic foraminifers (e.g., Culver, 2003; Thomas, in press).

Few completely recovered, well-dated marine $\mathrm{K} / \mathrm{Pg}$ records are available to document the effects of biological disaster on sedimentation patterns. For example, although Zachos and Arthur (1986) showed that deep-sea carbonate accumulation did not recover for $>2 \mathrm{~m}$.y. after the mass extinction, a long-term, continuous record of deep-sea carbonate accumulation has only been generated for a single site (ODP Site 1001), where carbonate accumulation rates did not recover until 4 m.y. into the Paleogene (D'Hondt et al., 1998). Another example from drill holes (DSDP Leg 74) in the South Atlantic Ocean, Walvis Ridge, shows that carbonate accumulation and carbon isotope gradient recovery took millions of years (D'Hondt et al., 1996; Coxall et al., 2006). However, these records offer limited temporal resolution because of coring gaps and low-resolution chronologic control. With the benefit of the APC and employing a multiple-hole coring strategy, we were able to acquire a complete K/Pg section with the APC in two holes at Site 1262 (Walvis Ridge, Leg 208).

The boundary was cored at Sites 1262 and 1267. Double coring at these sites resulted in a total of four $\mathrm{K} / \mathrm{Pg}$ records. The lithologic sequence in the $\mathrm{K} / \mathrm{Pg}$ boundary interval is similar at both sites, as they differ in water depth by only $400 \mathrm{~m}$. At both Sites 1262 and 1267, the $\mathrm{K} / \mathrm{Pg}$ boundary records an abrupt transition from highly cyclic Maastrichtian clay-bearing nannofossil ooze with foraminifers (nannofossil Zone CC26) to overlying Paleocene dark reddish brown clay-rich foraminifer-bearing nannofossil ooze and nannofossil clay. This boundary coincides with a distinctive increase in magnetic susceptibility and a decrease in sediment lightness (Fig. F9), corresponding to an overall increase in the abundance of clays, oxides, and ash in the lowermost Paleocene. At Site 1262, microtectites are present at the boundary and overlying sediments grade upward into moderately bioturbated brown nannofossil- and foraminifer-bearing clay (foraminiferal Zones P $\alpha$ and P1a). Preliminary biostratigraphy shows the well-established abrupt change in plankton assemblages across the boundary at both sites

F9. The Cretaceous/Paleocene boundary from Walvis Ridge, p. 39.

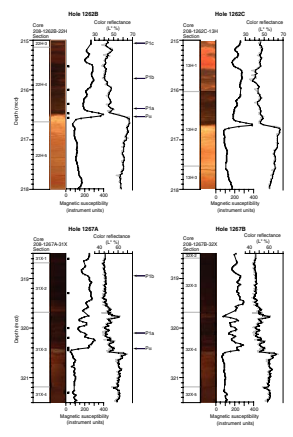




\section{KROON ET AL.}

(Luterbacher and Premoli Silva, 1964; Thierstein, 1982; Monechi, 1985). The white nannofossil ooze below the boundary yields diverse assemblages of the uppermost Maastrichtian Abathomphalus mayaroensis planktonic foraminiferal zone and nannofossil Zone CC26. The brown nannofossil- and foraminifer-bearing clay contains a high abundance of Woodringina hornerstownensis, Chiloguembelina midwayensis, and Chiloguembelina morsei as well as increasing abundance of Parvularugoglobigerina eugubina through the basal Paleocene $(\mathrm{P} \alpha)$. Based on this preliminary analysis, Zone P0 is not present at Walvis Ridge. However, this zone is absent at many deep-sea locations, and its absence may be ecologically determined rather than indicative of an unconformity (Norris et al., 1999). The substantial thicknesses of the uppermost Maastrichtian Micula prinsii Zone and the lowermost Danian P. eugubina Zone indicate that the $\mathrm{K} / \mathrm{Pg}$ boundary is paleontologically complete. Moreover, the cycle stratigraphy is very robust with distinct spectral peaks in the precession and eccentricity bands. Thus, the Walvis Ridge sections provide a well-preserved and relatively detailed record of this major extinction event and the subsequent biotic recovery.

Preliminary results of postcruise work on the $\mathrm{K} / \mathrm{Pg}$ boundary are shown in Figures F10 and F11 (Kroon et al., unpubl. data). High-resolution carbonate content and bulk carbon and oxygen isotope profiles show an abrupt change of dominant late Maastrichtian precessional cycles to marked early Paleocene short- and long-term eccentricity cycles (e.g., D'Hondt et al., 1996) at the K/Pg boundary (Fig. F10). The reason for the pronounced increase in the amplitude of the short- and long-term eccentricity frequencies at the $\mathrm{K} / \mathrm{Pg}$ boundary is certainly related to the meteorite impact, although it is not yet clear which oceanic feedback processes responded to eccentricity forcing (D'Hondt et al., 1996). Carbonate accumulation shows that carbonate production at the $\mathrm{K} / \mathrm{Pg}$ boundary ceased almost completely (Fig. F12). The bulk carbon isotope stratigraphy shows a large, abrupt shift toward negative values synchronous with the boundary and a more gradual change also toward negative values above the abrupt shift. The abrupt fall in values of $\sim 1 \% 0-1.5 \%$ at the boundary would represent eradication of the carbon isotope gradient in the water column in response to biological disaster in the pelagic realm (Kump, 1991; Zachos et al., 1989) in keeping with the large loss in carbonate production. The following gradual reduction in carbon isotope values is not observed in all carbon isotope records and thus difficult to reconcile.

Bulk oxygen isotope stratigraphy shows the highest values of the entire late Maastrichtian-early Paleocene record just above the K/Pg boundary. This implies that surface waters of the South Atlantic cooled substantially, several degrees, for a period of several thousand years, although this phenomenon needs to be confirmed by oxygen isotope analysis of individual species of planktonic foraminifers.

The global CCD is thought to have deepened immediately following the extinction event (Zachos et al., 1989), in response to the sudden loss of carbonate production (Caldeira et al., 1990). Although various methods of documenting CCD change are available, we used the variability of the weight of the residue in the $>63-\mu \mathrm{m}$ fraction relative to the total weight (weight percent) as a proxy coupled with variability in carbonate content. The preservation state of the foraminifers in relation to this proxy was examined by using scanning electronic microscopy. Well-preserved foraminifers occurred synchronously with high weight percent of the residue in the $>63-\mu \mathrm{m}$ fraction. The profile of the weight percent of the residue in the $>63-\mu \mathrm{m}$ fraction shows that high weights
F10. Residue in the $>63-\mu \mathrm{m}$ fraction at the K/Pg boundary, p. 40.

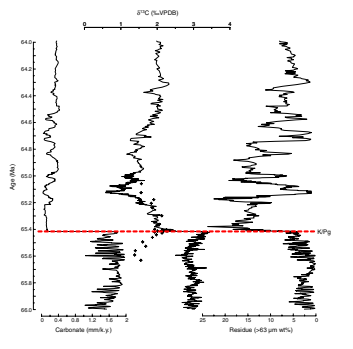

F11. Stable isotope bulk carbonate across the K/Pg boundary, p. 41.

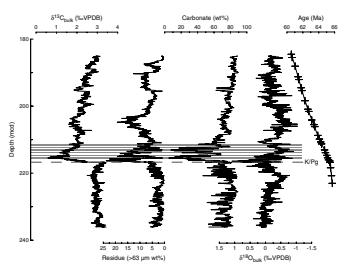

F12. Sedimentation and carbonate accumulation rates, p. 42 .

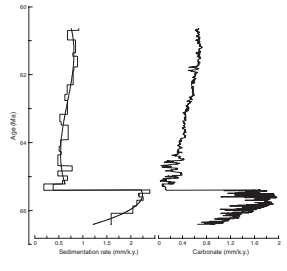




\section{KROON ET AL.}

are synchronous with relatively high percentage carbonate contents of the sedimentary record. Abrupt improvement of planktonic foraminiferal preservation was found uniquely at the K/Pg boundary, after which most of the variability oscillates at the frequencies of the short- and long-term eccentricity cycles.

Deep-sea benthic foraminifers at Site 1262 (as at other locations worldwide) did not undergo significant extinction. In contrast with some other locations, however (e.g., Alegret and Thomas, 2004, 2005), the Site 1262 record also shows no strong decrease in food delivery to the seafloor after the K/Pg boundary, with benthic foraminiferal accumulation rates indicative of a strongly fluctuating, at times very high, food supply (Alegret and Thomas, in press).

\section{Mid-Paleocene Biotic Event}

A prominent 10- to 30-cm-thick dark brown clay-rich calcareous nannofossil ooze was found at Sites 1262 and 1267, and a 10-cm-thick brown nannofossil chalk was found at Site 1266 (Röhl et al., 2004). These layers show a pronounced peak in magnetic susceptibility and XRF Fe data (Westerhold et al., submitted [N1]) that reflects an increase in clay content. Preliminary micropaleontological investigations suggest that this interval represents a short-lived event of considerable evolutionary significance. This interval corresponds to the P4 Globanomalina pseudomenardii planktonic foraminiferal zone and coincides with the evolutionary first occurrence of the nannofossil Heliolithes kleinpellii, an important component of upper Paleocene assemblages and a marker for the base of Zone CP5 (NP6) (lower upper Paleocene; $58.2 \mathrm{Ma}$ ).

The event was also identified at Leg 113 Sites 689 and 690 (Thomas, 1990) and at Leg 198 Sites 1209-1212 (Bralower, Premoli Silva, Malone, et al., 2002; Petrizzo, 2005). Fundamental changes in faunal populations occur before, during, and after deposition of the clay-rich ooze. Planktonic foraminifers in the clay-rich layer are characterized by a largely dissolved low-diversity assemblage dominated by representatives of the genus Igorina (mainly Igorina tadjikistanensis) (Petrizzo, 2005). This low-diversity assemblage suggests some kind of oceanic perturbation of unknown origin. Together with the documented severe dissolution in this interval, the observed lithologic changes are likely to represent a response to increased seafloor carbonate dissolution caused by a transient shoaling of the lysocline and CCD. Regardless of origin, it is now clear from the high-resolution stratigraphy of the Leg 208 sites that this is a global event. Ongoing isotopic investigations should shed light on the nature of this extreme dissolution event (Röhl et al., 2004).

\section{Paleocene/Eocene Thermal Maximum}

The Paleocene/Eocene boundary was successfully recovered in multiple holes at five sites (e.g., Sites 1262, 1263, 1265, 1266, and 1267), spanning an estimated paleodepth range of $\sim 1500$ to $\sim 3500 \mathrm{~m}$. Shipboard physical property, lithologic, and biostratigraphic data indicate complete recovery of the Paleocene-Eocene transition interval at all sites except Site 1265 (see the Leg 208 Initial Reports volume; Zachos, Kroon, Blum, et al., 2004). Each boundary section is marked by a distinct clay layer. At the onset of the PETM, carbonate content plummets to $\sim 0 \mathrm{wt} \%$, producing a pronounced lithologic shift from nannofossil ooze to a clay interval that roughly doubles in thickness from $\sim 20$ to 
$\sim 50 \mathrm{~cm}$ down the depth transect (Fig. F13). This general pattern of decreased carbonate content is present in all marine PETM records (e.g., Bralower et al., 1997; Thomas and Shackleton, 1996; Thomas, 1998; Thomas et al., 2000) and has been attributed to a massive methane flux to the ocean-atmosphere.carbon reservoir that elevated $\mathrm{pCO}_{2}$ levels, decreased carbonate ion concentrations, and shoaled the carbonate saturation profile (Dickens et al., 1995, 1997). Leg 208 records, however, clearly demonstrate that the South Atlantic paleo-CCD shoaled much more $(>2000 \mathrm{~m})$ than predicted by current models $(\sim 400 \mathrm{~m})$ (Dickens et al., 1997), suggesting release of a much larger volume of carbon.

Biostratigraphically, the onset of clay deposition coincides with the highest occurrence of the benthic foraminifer Stensioeina beccariiformis and other typical upper Paleocene taxa (Fig. F13). Calcareous microfossils are absent to extremely rare and generally poorly preserved in the lowermost clay, reflecting some combination of deleterious benthic conditions, decreased carbonate export production, and intensified carbonate dissolution. Lowermost Eocene benthic foraminifers near the base of the clay layer (Fig. F13) are extremely low in abundance and diversity and minute in size. Aragonia aragonensis, Tappanina selmensis, Oridorsalis umbonatus, and Bulimina spp. dominate at shallower Sites 1263, 1265, and 1266, whereas abyssaminids and clinapertinids are common at these sites but dominate at deeper Sites 1262 and 1267 and in the lowermost sample at the shallower sites. In general, assemblage composition in the clayey intervals is strongly variable. Nannofossils are common and show only slight dissolution. The last appearance of the planktonic foraminifer Morozovella velascoensis roughly coincides with the onset of the PETM, and no related "excursion" taxa (e.g., Morozovella allisonensis, Acarinina sibaiyaensis, and Acarinina africana) occur within the PETM-a biogeographic pattern that stands in stark contrast to those documented at lower and higher paleolatitudes (Kelly et al., 1998; Kelly, 2002). Planktonic foraminifers within the clay layer primarily consist of extremely rare and poorly preserved specimens of Acarinina soldadoensis. Nannofossil assemblages within the PETM clay are markedly poorer in preservation, lower in abundance and richness, and dominated by discoasters.

The base of the PETM recovery interval may be defined as the onset of increasing carbonate content, which produced a gradational upsection lithologic sequence at each site of nannofossil-bearing clay, nannofossil clay, clay-bearing nannofossil ooze, and, finally, nannofossil ooze. Recovery intervals are thicker at shallower sites, likely reflecting higher overall mass accumulation rates coupled with the time-transgressive deepening of the carbonate saturation profile. Magnetic susceptibility values are consistent with this scenario, with shallower sites showing more oscillations within the generally decreasing trends. As carbonate content increased through the PETM recovery interval, planktonic foraminiferal preservation improved and faunal abundance and richness increased to include morozovellids, acarininids, subbotinids, and rare globanomalinids. The first occurrences of the nannofossils Rhomboaster cuspis and Rhomboaster calcitrapa, basal members of the RhomboasterTribrachiatus lineage, are within the recovery interval and provide potentially isochronous biomarkers for intersite correlation. Above these nannofossil first occurrences, three prominent bioevents occur in varying stratigraphic order at all five sites: (1) benthic foraminiferal compositions shift from lowermost Eocene low-diversity diminutive assemblages to lower Eocene moderate-diversity assemblages, (2) nannofossil assemblages show a marked relative decrease in Fasciculithus
F13. Core photos and $\mathrm{CaCO}_{3}$ across the P/E boundary, p. 43.

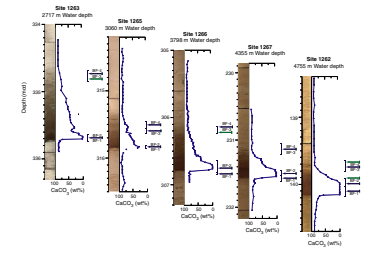


spp., and (3) nannofossil assemblages also show a marked relative increase in Zygrhablithus bijugatus. This relative increase in $Z$. bijugatus typically coincides with the benthic foraminiferal extinction event (BEE) in other regions (e.g., Shatsky Rise and central Pacific) but occurs later at Walvis Ridge and may be correlative with the FasciculithusRhomboaster abundance reversal reported at equatorial Pacific Sites 1220 and 1221 (Lyle, Wilson, Janecek, et al., 2002). These intersite differences in bioevent ordination may represent incomplete sampling coverage or real paleoenvironmental diachroneity between sites.

A number of postcruise investigations were undertaken to identify the impacts of the PETM on regional climate, ocean chemistry and ecology, and sediment accumulation. These investigations include (1) establishing high-resolution isotope and geochemical stratigraphies for improving site to site correlations and computing carbonate accumulation rates (Zachos et al., 2005; Röhl et al., submitted [N2]), (2) developing an organic compound-specific carbon isotope record (Hasegawa et al., this volume), (3) establishing changes in the general mineralogy and grain size distribution of the nonsoluble sediment fraction (Nicolo and Dickens, this volume), and (4) evaluating the local ecological impacts on phytoplankton and benthic foraminifers.

\section{High-Resolution Stable Isotope Stratigraphies}

Bulk carbon isotope records have proved to be useful for first-order correlation of marine P/E boundary sections. Each of the boundary sections in the Leg 208 sites was sampled at 1- to $5-\mathrm{cm}$ intervals for the purpose of developing high-resolution isotope stratigraphies across the clay layers. These samples were supplemented with continuous channel samples (quarter and half-rounds) collected postcruise. The stable isotope analyses were carried out in four different laboratories (University of California, Santa Cruz, University of Florida, Bremen University, and Frjei University) (Zachos et al., 2005).

Each of the five bulk isotope records show nearly identical patterns over a 3- to 4-m interval spanning the boundary, with a prominent negative carbonate isotope excursion (CIE) coeval with the clay layers (Fig. F14). The thickness of the excursion layers and magnitudes of the CIE, however, systematically decrease with depth, implying a preservation bias. Site 1263 shows the largest CIE of about $-3.0 \%$, whereas Site 1262 has a $-2.0 \%$ excursion. This pattern is attributed to the combined effects of dissolution and mixing of preexcursion carbonate in the clay layers. Excluding these low-carbonate intervals, the carbon isotope stratigraphies were used to correlate the five sites to each other as well as to ODP Site 690 (Zachos et al., 2005). This correlation provided the primary basis for determining the duration of deposition of the clay layer, 40 k.y., and the duration of the time lag for carbonate deposition to resume at the deepest site relative to the shallowest, and hence, the recovery time for the CCD.

The timescale for recovery of the CCD recorded in the Leg 208 cores is consistent with general carbon cycle theory. In simulations of the ocean carbon system response to a rapid ( $300 \mathrm{yr})$ anthropogenic $\mathrm{CO}_{2}$ pulse, a release of $4500 \mathrm{Gt} C$ results in severe carbonate undersaturation over most of the deep sea for a period exceeding $10 \mathrm{k} . \mathrm{y}$. (Archer et al., 1997). Saturation levels did not recover for 40 k.y., and it took more than 100 k.y. for most of the excess carbon to be sequestered. Moreover, the restabilization of carbonate content and magnetic susceptibility values slightly higher and lower, respectively, than their pre-PETM values, are also consistent with theory. This pattern, which is present at other
F14. Bulk sediment carbon isotope records, p. 44.

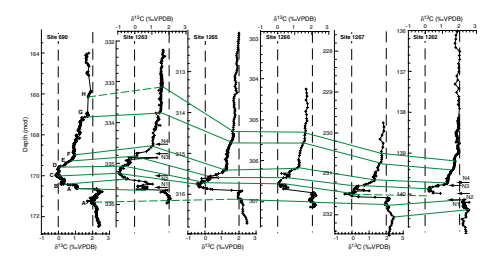




\section{KROON ET AL.}

PETM sites (e.g., Southern Ocean Site 690), occurs in model simulations as a transient lysocline overdeepening in response to oceanic mass balancing of increased bicarbonate, carbonate, and $\mathrm{Ca}^{2+}$ concentrations (by way of enhanced chemical weathering and runoff) (Dickens et al., 1997).

\section{Compound-Specific Carbon Isotope Stratigraphies}

Another precruise objective was to determine whether the Paleocene and Eocene sediments on Walvis Ridge contained sufficient quantities of marine organic matter to isolate specific organic compounds, such as alkenones, for stable carbon isotope analysis. Such a record could potentially be used to reconstruct changes in $\mathrm{pCO}_{2}$ through the PETM. Shipboard gas chromatographic (GC) analyses of $5-\mathrm{cm}$ quarter-round samples collected from sediments spanning the clay layer revealed the near-complete absence of alkenones and instead the presence of terrestrially derived $n$-alkanes. Based on these results, a decision was made to generate a detailed compound-specific carbon isotope record across the $\mathrm{P} / \mathrm{E}$ boundary. Quarter-round samples, $5 \mathrm{~cm}$ in length, were collected from the shallowest Site 1263 during the postcruise sampling party. For GC-mass spectrometry (MS) analysis, the samples were prepared following standard techniques to isolate insoluble organic residues (Hasegawa et al., this volume). Three heavy $n$-alkanes, nonacosane $\left(n-\mathrm{C}_{29}\right)$, hentriacontane $\left(n-\mathrm{C}_{31}\right)$, and tritriacontane $\left(n-\mathrm{C}_{33}\right)$, were isolated in sufficient quantities for carbon isotope analysis. The $\delta^{13} \mathrm{C}$ values range from $-26 \%$ to $-33 \%$ (Fig. F15). The record shows a prominent $\sim 5 \%$ negative excursion coincident with the base of the clay layer. The isotope profiles of the three normal alkanes are similar to that of carbonate carbon, though the magnitude of the excursion is larger, roughly $4 \% 0-$ $5 \%$. In addition, the $n$-alkane records show an inflection at 334.70 meters composite depth (mcd), which is roughly equivalent to the CIE in the bulk carbonate record.

These long-chain $n$-alkanes are a common component of terrestrial vegetation. The low carbon isotope values are consistent with this interpretation, indicating they were derived from C-3 plants, most likely in South Africa. The heavy $n$-alkanes are a common component of leaf waxes, which tend to be highly resistant to degradation, a possible reason for the high abundances in the Leg 208 sediments relative to compounds from marine organic matter. The magnitude of the excursion is considerably larger than that recorded in carbonates from these same cores. This particular finding is significant, as it is consistent with observations of other terrestrial carbon isotope records which typically show large excursions, on the order of $5 \% 0-6 \%$, or nearly twice that of marine records (Koch et al., 1992; Bowen et al., 2004; Pagani et al., 2006). Several models have been proposed to explain the differing magnitudes of the marine and terrestrial CIEs including (1) truncation of the marine carbonate records by dissolution and bioturbation (Zachos et al., 2005), (2) damping of the marine signal by lower $\mathrm{pH}$ and $\mathrm{CO}_{3}$ content, and (3) amplification of terrestrial vegetation signal because of higher $\mathrm{pCO}_{2}$ and/or humidity (i.e., Bowen et al., 2004). It is also possible that the source of $n$-alkanes (i.e., type of plants) changed during the PETM. Because this is the first time that both the marine and terrestrial signals were reconstructed from the same core, we can eliminate bioturbation as the primary source of the reduced amplitude of the marine records.

Another important feature of this record is the relative $\delta^{13} \mathrm{C}$ offsets between the three groups of analyzed $n$-alkanes. In general, the heavier
F15. $n$-alkane $\delta^{13} \mathrm{C}$ and bulk carbonate isotopes, p. 45 .

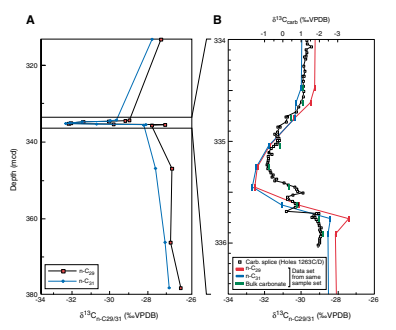




\section{KROON ET AL.}

$n$-alkanes $\left(n-\mathrm{C}_{33}\right)$ tend to have consistently lower $\delta^{13} \mathrm{C}$ values than the lighter, similar to the pattern in modern plants. This intercompound fractionation offset, however, decreases during the PETM, implying some change in plant metabolism/physiology. Whether this change in fractionation was caused by the effects of higher $\mathrm{pCO}_{2}$, humidity, species composition, or metabolic rates is unknown.

\section{Calcareous Algae}

Large shifts in the relative abundances of calcareous algae have been recorded in all marine $\mathrm{P} / \mathrm{E}$ boundary sections studied to date (e.g., Monechi et al., 2000; Bralower, 2002; Tremolada and Bralower, 2004; Raffi et al., 2005; Gibbs et al., 2006). Similarly, large shifts occur in the Leg 208 sites. Some of the changes are clearly related to dissolution, whereas other shifts appear to reflect actual paleoecological responses. Given the recent interest in the potential impacts of ocean acidification on marine calcifiers, particularly phytoplankton, several postcruise studies were undertaken to ascertain changes in nannofossil assemblages through this event.

Initial results reveal several important patterns involving several major groups of nannofossils including genera Fasciculithus, Rhomboaster, Tribrachiatus, and Discoaster (Monechi and Angori, this volume; Agnini et al., submitted [N3]). At the deeper Sites 1262 and 1266, it is clear that dissolution strongly influenced abundance patterns. In particular, the abundances of dissolution-resistant taxa such as Rhomboaster are much higher than at the shallowest site. As such, we will only discuss patterns observed at the shallowest Site 1263 where preservation is moderate to good throughout. Only in a 6-cm interval (between 335.68 and 335.62 mcd), corresponding to an earlier stage of the CIE onset, do assemblages show the effect of dissolution that, nevertheless, does not significantly alter the assemblages in terms of taxonomic composition. The recorded biostratigraphic signals are diverse and involve different components of the nannofossil assemblages. The changes can be divided into successive biohorizons, marked by increased/decreased abundances of taxonomic groups, sudden appearances, or ranges of individual taxa, all of which are described below and labeled as Biohorizons N1-N5 in Figure F16.

The N1 biohorizon is coincident with the onset of the CIE and is defined by a drastic decrease in diversity and abundance of the genus Fasciculithus. The turnover involved the characteristic large species in fasciculith assemblages of the uppermost Paleocene, like Fasciculithus richardii, F. schaubii, F. hayi, F. toni, and F. mitreus, that suddenly disappeared. This event is recorded in Paleocene/Eocene boundary sections across the globe (Backman, 1986; Monechi et al., 2000; Raffi et al., 2005). At Site 1263, the N2 biohorizon coincides with the second step in the onset of the CIE, where survivor species of fasciculiths, Fasciculithus alanii, F. tympaniformis, and F. involutus, peak in abundance, with the interval of peak abundance in Fasciculithus correlated to the lowest diversity of benthic foraminifers. Also, the first occurrence of $F$. thomasii is recorded, closely followed by the appearance of the peculiar forms of asymmetrical and deformed discoasterids. These discoasterids show an asymmetrical radial structure with a prominent irregular central knob. The first occurrence of rare, small specimens of Discoaster salisburgensis further characterizes this interval. The occurrences of the two shortlived and deformed discoasterids further delimit the N2 biohorizon. The N3 biohorizon is marked by the base of the Rhomboaster calcitrapa group. Within the CIE, Rhomboaster morphotypes belonging to the
F16. Biohorizons N1-N5, Site 1263, p. 46.

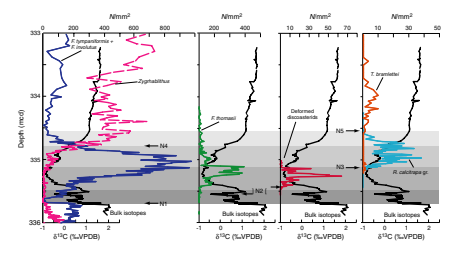




\section{KROON ET AL.}

spined $R$. calcitrapa group and $R$. cuspis have the lowermost occurrence. $R$. calcitrapa group specimens have been observed in most of the known $\mathrm{P} / \mathrm{E}$ sections and appear to represent a globally distributed evolutionary event. In the upper part of the CIE, at the beginning of the "recovery interval" where bulk $\delta^{13} \mathrm{C}$ values start to increase and weight percent $\mathrm{CaCO}_{3}$ content further increases (exceeding $60 \mathrm{wt} \%$ at Site 1263), we record a sharp decrease of genus Fasciculithus and an increase in the genus Zygrhablithus. This crossover in abundance Fasciculithus vs. Zygrhablithus defines biohorizon N4. Because this event is consistently recorded close to the P/E boundary in different oceanic settings (Bralower, 2002; Tremolada and Bralower, 2004; Gibbs et al., 2006), it is clearly related to PETM environmental changes. Zygrhablithus is likely occupying the ecological niche vacated by the permanent global decline of Fasciculithus (Bralower, 2002). The interval between Biohorizons N4 and N5 coincides with the recovery phase in bulk $\delta^{13} \mathrm{C}$, and it is also characterized by increases in the relative abundances of Discoaster and Sphenolithus. Biohorizon N5 is delineated by the uppermost occurrence of the spined Rhomboaster spp. An increase in abundance of Tribrachiatus bramlettei is recorded at the last occurrence of spined Rhomboaster. Biohorizon N5 is correlative with the full recovery of carbonate content at all sites, when $\mathrm{CaCO}_{3}$ percentage stabilized at $\sim 90 \mathrm{wt} \%$ (Zachos et al., 2005) (Figs. F14, F16). The high abundances of this particular group may be a consequence of the highly oversaturated state of the ocean.

\section{Terrigeneous Sediment Flux}

The terrigenous fraction of lower lower Paleogene sediments is likely composed of both hemipelagic and eolian material at all Leg 208 sites. Terrigenous component-specific grain-size distributions (Fig. F17) indicate that Site 1267, positioned on a deeper flank of Walvis Ridge, received a greater flux of hemipelagic sediment than did the relatively shallow near-crest Site 1263 during this interval (Nicolo and Dickens, this volume). This observation is only possible because of the unique geologic setting of Walvis Ridge and the depth transect strategy of Leg 208 and is consistent with both previous work at DSDP Site 527 (Rea and Hovan, 1995) and general views of open-ocean terrigenous deposition (e.g., Rea, 1994). These results imply that an early Paleogene eolian grain-size record may be gleaned from Site 1263 samples (Nicolo and Dickens, this volume).

\section{Elmo (Eocene Thermal Maximum-2)}

At $\sim 20-35 \mathrm{~m}$ above the P/E boundary, a red-colored 5- to $15-\mathrm{cm}$ carbonate-depleted layer was found at all sites with lower Eocene strata (Fig. F18). During the cruise this layer was tentatively placed in Chron $\mathrm{C} 24 \mathrm{n}$ and called the Chron C24n event. Subsequent postcruise work suggests the layer may lie just below Chron C24n (Bowles, this volume). Moreover, a second name, Elmo, was applied to the event. The Elmo shows similar color characteristics to the P/E boundary layer as well as a drop in calcium carbonate content and an increase in magnetic susceptibility and natural gamma radiation (NGR) values, but these changes are not as significant. The Elmo is characterized by a double peak in the $1-\mathrm{cm}$ sampled point magnetic susceptibility records of all sites, which are marked by events $a$ and $b$ in Figure F18. At the shallowest sites (Sites 1263-1266), events a and b are most distinctly developed, whereas at the deepest sites (Sites 1267 and 1262) they are merged. At the latter sites, an additional peak in magnetic susceptibility
F17. Grain-size distributions, Sites 1263 and 1267, p. 47.

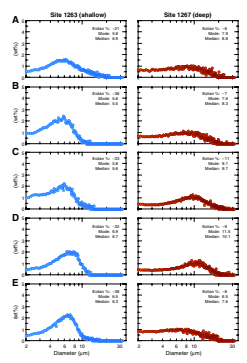

F18. Bulk carbonate $\delta^{13} \mathrm{C}$ and MS across the Elmo horizon, p. 48.

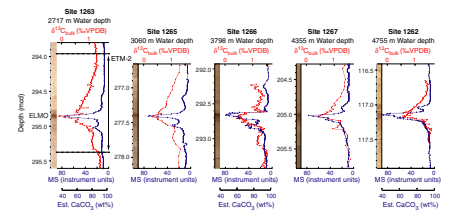




\section{KROON ET AL.}

values is observed slightly above the main clay layer. At middepth Site 1266 , a thin white-colored layer is found immediately above the redcolored horizon. The uppermost occurrence of nannofossil $D$. multiradiatus is recorded close to the Elmo. This layer, which appears to be present in the magnetic susceptibility records of sites drilled on Shatsky Rise, is associated with benthic foraminiferal assemblages similar in character to those of the PETM. This implies a transient shift of paleoenvironmental conditions toward those documented for the PETM.

Postcruise studies of the Elmo include stable isotope analyses of bulk sediment and foraminifers collected from samples taken at 1-cm spacing across the event. This work reveals negative carbon and oxygen isotope excursions in both bulk and planktonic and benthic foraminifer samples coeval with the low-carbonate layer (Fig. F19) (Lourens et al., 2005). The magnitude of the carbon isotope excursion, $1.5 \% 0-2.0 \%$, is roughly half that of the PETM. In addition, the onset seems more gradual. The oxygen isotope excursion in benthic foraminifers is on the order of $0.8 \%$, suggesting $2^{\circ}-3^{\circ} \mathrm{C}$ warming, again about $30 \%-40 \%$ of that observed for the PETM. As discussed above, initial cycle stratigraphic analysis of the magnetic susceptibility data suggest that this event lies within five 400-k.y. eccentricity cycles of the PETM, or about 2 m.y. younger (Lourens et al., 2005), though subsequent work involving core scanned XRF data suggests a slightly shorter duration (Westerhold et al., in press). Given the similarity of key attributes of these hyperthermals (e.g., transient warming, benthic foraminiferal assemblage changes, and CIE), we designate the PETM as Eocene Thermal Maximum 1 (ETM-1), and the Elmo as Eocene Thermal Maximum 2 (ETM-2).

\section{$X$ Event (Eocene Thermal Maximum-3)}

We document a third thermal maximum in lower Eocene $(\sim 52 \mathrm{Ma})$ sediments. The prominent clay layer, named the " $\mathrm{X}$ " event, occurs in planktonic foraminifer Zone P7 and calcareous nannofossil Zone CP10 at four sites. Benthic foraminifers have low diversity and high dominance and are dominated by small individuals of Nuttallides truempyi and various abyssaminids, resembling the post-PETM extinction assemblages, with more severe effects at deeper sites. Calcareous nannofossil assemblages show similar trends to the PETM, with major changes in the genera Discoaster and Zygrhablithus, but with differences in magnitudes and fluctuations. High-resolution bulk carbonate stable isotope values at relatively shallow Site 1265 show a rapid, $0.6 \%$ o drop in ${ }^{13} \mathrm{C}$ and ${ }^{18} \mathrm{O}$, followed by an exponential recovery to preexcursion values (Röhl et al., 2005; Röhl et al., submitted [N2]), a pattern similar to that of the PETM and Elmo. Planktonic foraminiferal ${ }^{13} \mathrm{C}$ values (Morozovella subbotina and Acaranina soldadoensis) in the deepest Site 1262 decrease by $0.8 \% 0-0.9 \%$, those of the benthic foraminifer Nuttalides truempyi by $1 \%$. Evaluations for mechanisms for the widespread change in deepwater chemistry, its connection to the surface water response, and the temporal relation of the event, as well as the PETM and Elmo, with current astronomical solutions are still ongoing.

\section{Eocene/Oligocene Boundary and Early Oligocene Glacial Maximum}

Sediment recording the response of South Atlantic Ocean to global cooling and CCD deepening during the Eocene-Oligocene transition was recovered across a broad range of depths on the northeastern flank
F19. Stable isotopes of bulk sediment and single foraminifers across the Elmo horizon, Site 1263, p. 49.

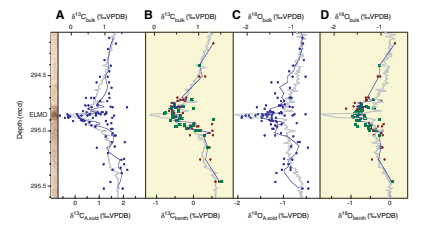




\section{KROON ET AL.}

of Walvis Ridge during Leg 208, but the transition is not well characterized biostratigraphically. The shallower Sites 1263 and 1265 contain the most complete records, but even at these sites, calcareous nannofossil and benthic and planktonic foraminiferal assemblages are affected by dissolution, downslope transport, and reworking.

Calcareous nannofossil preservation in the Eocene/Oligocene (E/O) boundary interval is moderate because of dissolution, etching, and common reworking. Nannofossil events that bracket the boundary are the uppermost occurrence of the rosette-shaped discoasters (last occurrence [LO] of Discoaster barbadiensis at $34.2 \mathrm{Ma}$ and LO of Discoaster saipanensis at $34.0 \mathrm{Ma}$ ) and that of Ericsonia formosa (32.9 Ma). The LO of $D$. saipanensis and the LO of $E$. formosa could be observed at all sites, but these are uppermost occurrences and thus are prone to reworking. The bottom of the increase in the abundance of Ericsonia obruta is at the E/O boundary (33.7 Ma) but was observed at Site 1263 only. Fortunately, the global increase in $\delta^{18} \mathrm{O}$ values in deep-sea benthic foraminifers (Oi-1; 33.6 Ma), occurring within the interval between the LO of D. saipanensis and the LO of E. formosa (34.0-32.9 Ma) (e.g., Zachos et al., 2001), is recovered clearly in the shallow Sites 1263, 1265, and 1266 (Fig. F20). At the deepest Site 1262, carbonate fossils were completely dissolved below the E/O boundary at 33.7 Ma (Fig. F20) (Liu et al., $2004 \mathrm{~b}$ ), and the lithologic change from brown clay below to light brown to gray nannofossil ooze or foraminifer-bearing nannofossil ooze above occurs abruptly over a $\sim 0.5-\mathrm{m}$ interval.

At all sites, a distinct increase in carbonate occurs starting from the E/O boundary (Fig. F21). This increase is associated with the strongest foraminifer dissolution, leading the EOGM by 100 k.y. The increased carbonate content across the boundary interval indicates that the lysocline and CCD deepened substantially and rapidly at the Walvis Ridge transect sites. In the latest Eocene, the lysocline was between the paleodepths of Sites 1266 and 1267. During the Eocene-Oligocene transition, the lysocline/CCD deepened abruptly to a depth below that of Site 1262 , at least $600 \mathrm{~m}$ deepening. The recovery of foraminiferal preservation on the basis of coarse fraction (carbonate grain size $>63 \mu \mathrm{m}$ ) lags by $\sim 400$ k.y. (Fig. F21), implying that the shift in carbonate preservation was triggered by changes in climate. This significant downward shift in lysocline/CCD in the E/O boundary interval has also been observed in other ocean basins (e.g., Zachos et al., 1996; Lyle, Wilson, Janecek, et al., 2002) and possibly reflects an increase in mechanical and chemical weathering rates on continents and related changes in ocean chemistry associated with global cooling (EOGM). The peak in carbonate content, however, is transient, as values decline shortly thereafter. This peak in carbonate value corresponds with a magnetic "normal" that may represent Chron C13n.

\section{Early Miocene High Abundance of Bolivinid Biserial Foraminifers}

An enigmatic feature of early Miocene oceanography was the socalled "high abundance of bolivinids (HAB) event" (Thomas, 1986, 1987; Smart, 1992; Smart and Murray, 1994; Smart and Ramsay, 1995). During this event ( 18.9-17.2 Ma) biserial foraminifers (assigned to the benthic genus Bolivina) were abundant at bathyal to abyssal depths in the eastern Atlantic and western Indian Ocean but were not observed in the western equatorial Atlantic Ocean, eastern equatorial Pacific Ocean (Thomas, 1985), or the Weddell Sea (Thomas, 1990), although the sedi-
F20. Stable oxygen and carbon isotopes of C. mundulus and bulk fragments of PF, p. 50.

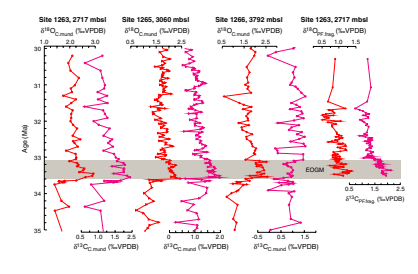

F21. Carbonate, and coarse fraction, and $L^{*}$, p. 51 .

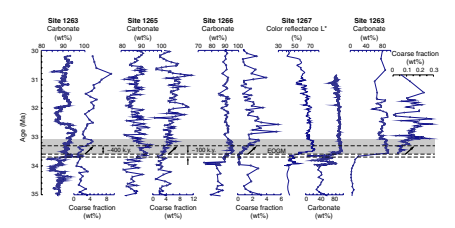




\section{KROON ET AL.}

ments in the correct size fraction and of the correct age were studied. The HAB event was enigmatic: Thomas $(1986,1987)$, Smart (1992), and Smart and Murray (1994) speculated that it might represent a period of low oxygen conditions during sluggish circulation. Smart and Ramsay (1995) argued that the event was associated with an oxygen-depleted water mass restricted to the eastern Atlantic and western Indian Oceans. In the modern oceans, however, such high relative abundances of bolivinids occur only where a severe oxygen minimum zone impinges on the seafloor (e.g., Bernhard and Sen Gupta, 1999), and there is no evidence for dysoxia (e.g., lamination or high organic carbon content) during the HAB event.

Smart and Thomas (2006) used morphological and stable isotope data of biserial foraminifers in samples (21.0-15.8 Ma) from Sites 1264 and 1265 to document that the early Miocene biserial forms are not benthic but planktonic and should be assigned to the genus Streptochilus. These biserial forms may have bloomed opportunistically, as suggested by their small size and high abundance, as also inferred for Paleogene biserial planktonic foraminifers (e.g., Hallock et al., 1991). During the interval of their high abundance, however, the high primary productivity did not result in high export productivity to the seafloor. Benthic foraminiferal accumulation rates have been described as a proxy for productivity (Herguera and Berger, 1991) but are low in the interval with highest abundance of biserials at Walvis Ridge and Site 608 (Diester-Haass and Billups, 2005). The low export productivity might be explained by the presence of a deep thermocline, in which regeneration rates of organic matter are high (e.g., Fischer et al., 2003), existing over a large geographic area.

The question remains: Why was there widespread, active, but intermittent upwelling of nutrient-rich waters in eastern Atlantic and western Indian only at that time (18.9-17.2 Ma)? The cause might be sought in circulation changes: Northern Component Water (NCW) may have been present between 19 and $17 \mathrm{Ma}$, its formation possibly triggered by the sinking of the Greenland-Scotland Ridge (Wright, 1998). Another possible trigger for NCW formation might be the development of a deep ACC at 19 Ma (e.g., Anderson and Delaney, 2005), leading to the formation of NCW (Sijp and England, 2004). A deep ACC is necessary for strong vertical mixing in the southern oceans, which leads to increased nutrient contents in upwelled waters such as in the Subantarctic Mode Waters, which presently support global productivity (Sarmiento et al., 2004). The gradual closing of the Mediterranean to the Indian Ocean (Harzhauser et al., 2002) may have increased the flow of surface waters from the Indian Ocean into the Atlantic around South Africa (Agulhas Leakage), leading to higher density waters in the North Atlantic (Weijer et al., 1999) and local deep convection (de Ruijter et al., 2006). Active deep convection in a deep ACC and in the Agulhas Leakage in the southern oceans thus could have provided the nutrient-rich waters upwelled in the eastern Atlantic and western Indian Ocean.

But if that were the case, then why did the high abundance of biserial planktonic foraminifers end at $17.5 \mathrm{Ma}$ ? Possibly, vigorous North Atlantic deep circulation ended somewhat earlier than envisaged by Wright (1998), thus ending vigorous upwelling in the eastern Atlantic Ocean. It is, however, not clear why the high abundances of biserial planktonic foraminifers did not resume in the middle Miocene, with increased cooling and formation of NCW. Possibly, upwelling at that later time became more constrained to its modern locations rather than 


\section{KROON ET AL.}

more widespread because of the overall increase of circulation vigor during the middle Miocene cooling.

\section{Cenozoic Seawater Chemical Evolution}

Several postcruise studies used fossils obtained from the Leg 208 cores to establish variations in seawater chemistry, specifically radiogenic $\mathrm{Nd}, \mathrm{Sr}$, and $\mathrm{Li}$ isotope distributions during key intervals of the Cenozoic. In the case of $\mathrm{Nd}$, the objective was to establish changes in deep ocean circulation patterns, whereas the Sr investigation was oriented toward establishing changes in geochemical fluxes. Li isotopes were used along with $\mathrm{Li} / \mathrm{Ca}$ data to evaluate changes in the character of chemical weathering of continental rocks.

Modern thermohaline circulation, with vigorous deepwater formation in the North Atlantic, was established some time in the middle Cenozoic (Wright and Miller, 1993). Traditionally, carbon isotope distributions as recorded in benthic foraminifers between the deep Pacific and Atlantic were used to established general circulation patterns. However, this approach has limited sensitivity during times when nutrient inventories were lower and/or productivity was suppressed. To establish the timing of NADW formation, Via and Thomas (2006) reconstructed changes in bottom water Nd isotope ratios in the South Atlantic during the Oligocene using samples from the Leg 208 depth transect. Bottom water Nd isotope ratios were obtained from analysis of fish teeth, which acquire Nd concentrations after deposition on the seafloor. Using the $\mathrm{Nd}$ isotope data from Walvis Ridge along with data from sites in the North Atlantic and Southern Ocean, they found an increase in the north-south $\mathrm{Nd}$ isotope gradient, suggesting the initial transition to a bipolar mode of deepwater circulation occurred in the early Oligocene, at $\sim 33$ Ma (Fig. F22). They attribute the onset and strengthening of deepwater production in the North Atlantic to tectonic deepening of the sill separating the Greenland-Norwegian Sea from the North Atlantic (Wright and Miller, 1996).

The late Paleocene-early Eocene warming trend has been attributed to increased volcanism and $\mathrm{CO}_{2}$ outgassing, most likely associated with North Atlantic rifting. In theory, such volcanism should have lowered the $\mathrm{Sr}$ isotopic composition of seawater. To test this, Hodell et al. (submitted [N4]) constructed a high-resolution Sr isotope record over the upper Paleocene and lower Eocene using foraminifers from Leg 208 cores (Fig. F23). The sampling interval, 50 k.y., is the highest such for this time interval and therefore reveals features not obvious in lowerresolution records. The main feature is a subtle, steady decline in ${ }^{87} \mathrm{Sr} /$ ${ }^{86} \mathrm{Sr}$ over the late Paleocene and early Eocene, followed by a slight rise through the middle Eocene. The decline coincides with a long-term gradual warming that culminates in the EECO. This pattern of decreasing ${ }^{87} \mathrm{Sr} /{ }^{86} \mathrm{Sr}$ coeval with increased warming has been documented in the Cretaceous (e.g., Jones and Jenkyns, 2001) and has been attributed to increased flood basalt volcanism and $\mathrm{CO}_{2}$ outgassing. Thus, the Leg $208{ }^{87} \mathrm{Sr} /{ }^{86} \mathrm{Sr}$ record implies a similar connection between volcanism and climate in the Paleogene.

The concentration of Li in the ocean is thought to be controlled by variations in hydrothermal fluxes. Using planktonic foraminifers from Site 1264 along with samples from several other ODP cores, Hathorne and James (2006) reconstructed Li variations for the Atlantic and Pacific ocean over the last 18 m.y. The $\delta^{7} \mathrm{Li}$ records for the Atlantic and Pacific
F22. Nd isotope record, p. 52.

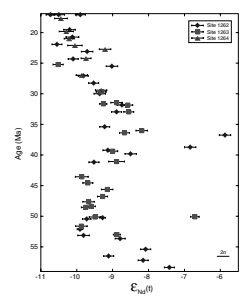

F23. Sr isotope results, p. 53.

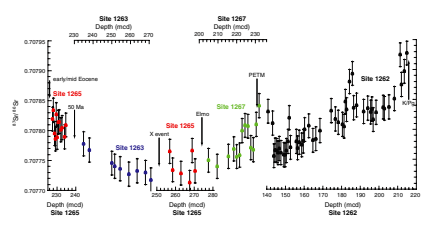




\section{KROON ET AL.}

look identical, suggesting that the patterns reflect changes in mean ocean Li (Fig. F24). Their findings also suggest very little change in Li/ $\mathrm{Ca}$ ratios. By assuming that the hydrothermal flux of Li into the oceans and the flux of Li removed from the oceans during low-temperature uptake by marine basalts and sediments have not changed significantly since $18 \mathrm{Ma}$ and using published records for the seawater Ca concentration, the seawater $\mathrm{Li} / \mathrm{Ca}$ and $\delta^{7} \mathrm{Li}$ records are used to estimate global average river $\delta^{7} \mathrm{Li}$ and Li fluxes. This analysis requires a decrease in the riverine flux of dissolved Li between 16 and $8 \mathrm{Ma}$ but an increase in $\delta^{7} \mathrm{Li}$ value of the riverine input. These data imply that both silicate weathering rates and weathering intensity decreased over this interval, which may have contributed to changing levels of atmospheric $\mathrm{CO}_{2}$. In contrast, the computations indicate riverine flux of $\mathrm{Li}$ has increased since 8 Ma while $\delta^{7} \mathrm{Li}$ has increased. This implies that the silicate weathering rate has increased, while weathering intensity has decreased.

\section{SUMMARY}

Leg 208 was originally conceived to test a single hypothesis, that the dissociation of methane hydrate of an unprecedented scale at $55 \mathrm{Ma}(\mathrm{P} / \mathrm{E}$ boundary) initiated a brief but extreme episode of global warming. In theory, such an event would profoundly impact the carbonate saturation state of the ocean, the expression of which should be preserved in deep-sea sediments (Dickens et al., 1997, 1995). In essence, the rapid injection of methane-derived carbon into the atmosphere and ocean should be recorded by distinct spatial and temporal patterns of change in the deposition of carbonate sediments. Such changes should be contemporaneous on a global scale, affecting all major ocean basins and exhibiting diagnostic patterns in carbonate preservation related to gradients in paleodepth. A key test would involve establishing depthdependent changes in carbonate preservation across the P/E boundary in at least two major ocean basins. To evaluate the gradient of carbonate saturation state, a transect of pelagic sections across a broad paleodepth range would be required for each ocean basin to elucidate both the temporal and spatial evolution of ocean chemistry from its onset through its ultimate recovery.

Leg 208 fulfilled its mission by successfully coring an array of Paleogene sedimentary sections spanning water depths between 2300 and $4700 \mathrm{~m}$ and recovering at least one complete $\mathrm{P} / \mathrm{E}$ boundary layer using the APC at each of five sites. This collection of boundary clay layers shows a clear pattern of change in lithology as a function of depth, which, by most measures, appears consistent with a shoaling of the CCD as caused by the rapid release of a large mass of carbon (>4500 Gt C). This was confirmed with postcruise work, which firmly established the relative timing of this clay layer to the global CIE.

The important scientific contributions of Leg 208 are not limited to the P/E boundary; several other key objectives were achieved. For one, the upper Paleocene and lower Eocene sections that enclose the boundary layer were recovered more or less intact at three sites (Sites 1262, 1263, and 1267). These sections, which are complete and relatively expanded, are characterized by distinct bedding cycles that will provide the basis for establishing a high-resolution, orbitally tuned timescale, a basic requirement for constraining rates of change and for refining the approximate ages of chron boundaries where possible. Moreover, with the composite sections for each site, it became evident that other un-
F24. Foraminiferal $\delta^{7} \mathrm{Li}$ and $\mathrm{Li} / \mathrm{Ca}$, p. 54 .

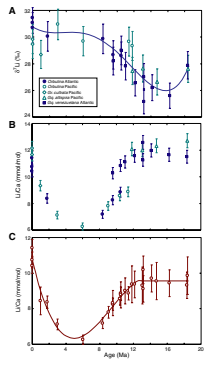




\section{KROON ET AL.}

usual clay layers and, by association, climatic extremes, occurred during early Eocene Chrons C24r and C24n (Elmo and X events, respectively). Postcruise studies found carbon isotope excursions in these horizons, implying these events may have origins similar to the PETM. Also, the pronounced lithologic cycles have been used to develop an orbital chronology for much of the upper Paleocene and lower Eocene, thus establishing the approximate duration of magnetochrons and the time separating these hyperthermals.

In addition, the K/Pg boundary interval was recovered at two sites (Sites 1262 and 1267) and the E/O boundary was recovered at five sites $(1262,1263,1265,1266$, and 1267). The former is also characterized by a pronounced cyclicity that clearly changes character across the boundary. Postcruise research has documented changes in biogenic carbonate accumulation and preservation on orbital timescales across the K/Pg boundary along with variations in isotopes, particularly during the long recovery following the extinctions at the K/Pg boundary. The E/O boundary is characterized by a prominent lithologic transition from clays to carbonates that becomes more pronounced at the deepest sites. The new stable isotope records show that this major shift in Atlantic Ocean carbon chemistry coincides with the onset of major glaciation on Antarctica. Other postcruise investigations are establishing in detail important changes in deep-sea circulation and seawater chemical evolution in relation to the major Cenozoic climatic events.

The crucial scientific contributions of Leg 208 are just being realized in numerous postcruise investigations of the many thousands of samples collected. This work will undoubtedly continue to make important advances for years to come.

\section{ACKNOWLEDGMENTS}

We thank T. Bralower and P. Wilson for critical reviews, and Heather McCarren for comments. This research used samples and/or data provided by the Ocean Drilling Program (ODP). ODP is sponsored by the U.S. National Science Foundation (NSF) and participating countries under management of Joint Oceanographic Institutions (JOI), Inc. 


\section{REFERENCES}

Alegret, L., and Thomas, E., 2004. Benthic foraminifera and environmental turnover across the Cretaceous/Paleogene boundary at Blake Nose (ODP Hole 1049C, Northwestern Atlantic). Palaeogeogr., Palaeoclimatol., Palaeoecol., 208(1-2):59-83. doi:10.1016/j.palaeo.2004.02.028

Alegret, L., and Thomas, E., 2005. Cretaceous/Paleogene boundary bathyal paleoenvironments in the central North Pacific (DSDP Site 465), the northwestern Atlantic (ODP Site 1049), the Gulf of Mexico and the Tethys: the benthic foraminiferal record. Palaeogeogr., Palaeoclimatol., Palaeoecol., 224(1-3):53-82. doi:10.1016/ j.palaeo.2005.03.031

Alegret, L., and Thomas, E., in press. Deep-sea environments across the Cretaceous/ Paleogene boundary in the eastern South Atlantic Ocean (ODP Leg 208, Walvis Ridge). Mar. Micropaleontol. doi:10.1016/j.marmicro.2006.12.003

Anderson, L.D., and Delaney, M.L., 2005. Use of multiproxy records on the Agulhas Ridge, Southern Ocean (Ocean Drilling Project Leg 177, Site 1090) to investigate sub-Antarctic hydrography from the Oligocene to the early Miocene. Paleoceanography, 20:PA3011. doi:10.1029/2004PA001082

Archer, D., Kheshgi, H., and Maier-Reimer, E., 1997. Multiple timescale for neutralization of fossil fuel $\mathrm{CO}_{2}$. Geophys. Res. Lett., 24(4):405-408. doi:10.1029/97GL00168

Backman, J., 1986. Late Paleocene to middle Eocene calcareous nannofossil biochronology from the Shatsky Rise, Walvis Ridge and Italy. Palaeogeogr., Palaeoclimatol., Palaeoecol., 57(1):43-59. doi:10.1016/0031-0182(86)90005-2

Bains, S., Corfield, R.M., and Norris, R.D., 1999. Mechanisms of climate warming at the end of the Paleocene. Science, 285(5428):724-727. doi:10.1126/science.285.5428.724

Barrera, E., and Huber, B.T., 1991. Paleogene and early Neogene oceanography of the southern Indian Ocean: Leg 119 foraminifer stable isotope results. In Barron, J., Larsen, B., et al., Proc. ODP, Sci. Results, 119: College Station, TX (Ocean Drilling Program), 693-717. doi:10.2973/odp.proc.sr.119.167.1991

Barrera, E., and Huber, B.T., 1993. Eocene to Oligocene oceanography and temperatures in the Antarctic Indian Ocean. In Kennett, J.P., and Warnke, D.A. (Eds.), The Antarctic Paleoenvironment: A Perspective on Global Change. Antarct. Res. Ser., 49-65.

Barron, E.J., 1985. Explanations of the Tertiary global cooling trend. Palaeogeogr., Palaeoclimatol., Palaeoecol., 50(1):45-61. doi:10.1016/S0031-0182(85)80005-5

Bernhard, J.M., and Sen Gupta, B.K., 1999. Foraminifera of oxygen-depleted environments. In Sen Gupta, B.K. (Ed.), Modern Foraminifera: Dordrecht (Kluwer Academic Publishers), 141-160.

Bice, K.L., Scotese, C.R., Seidov, D., and Barron, E.J., 2000. Quantifying the role of geographic change in Cenozoic ocean heat transport using uncoupled atmosphere and ocean models. Palaeogeogr., Palaeoclimatol., Palaeoecol., 161(3-4):295-310. doi:10.1016/S0031-0182(00)00072-9

Boven, K.L., and Rea, D.K., 1998. Partitioning of hemipelagic and Eolian sedimentation in eastern Pacific core TR163-31B. J. Sediment. Res., 68:850-55.

Bowen, G.J., Beerling, D.J., Koch, P.L., Zachos, J.C., and Quattlebaum, T., 2004. A humid climate state during the Paleocene/Eocene Thermal Maximum. Nature (London, U. K.), 432(7106):495-499. doi:10.1038/nature03115

Bralower, T.J., 2002. Evidence of surface water oligotrophy during the late PaleoceneEocene Thermal Maximum: nannofossil assemblage data from Ocean Drilling Program Site 690, Maud Rise, Weddell Sea. Paleoceanography, 17(2):1-12. doi:10.1029/ 2001PA000662

Bralower, T.J., Premoli Silva, I., and Malone, M.J., 2002. New evidence for abrupt climate change in the Cretaceous and Paleogene: an Ocean Drilling Program expedition to Shatsky Rise, northwest Pacific. GSA Today, 12(11):4-10. doi:10.1130/10525173(2002)012<0004:NEFACC $>2.0 . C O ; 2$ 
Bralower, T.J., Premoli Silva, I., Malone, M.J., et al., 2002. Proc. ODP, Init. Repts., 198: College Station, TX (Ocean Drilling Program). doi:10.2973/odp.proc.ir.198.2002

Bralower, T.J., Thomas, D.J., Zachos, J.C., Hirschmann, M.M., Röhl, U., Sigurdsson, H., Thomas, E., and Whitney, D.L., 1997. High-resolution records of the late Paleocene Thermal Maximum and circum-Caribbean volcanism: is there a causal link? Geology, 25(11):963-966. doi:10.1130/0091-7613(1997)025<0963:HRROTL>2.3.CO;2

Bralower, T.J., Zachos, J.C., Thomas, E., Parrow, M., Paull, C.K., Kelly, D.C., Premoli Silva, I., Sliter, W.V., and Lohmann, K.C., 1995. Late Paleocene to Eocene paleoceanography of the equatorial Pacific Ocean: stable isotopes recorded at Ocean Drilling Program Site 865, Allison Guyot. Paleoceanography, 10(4):841-865. doi:10.1029/95PA01143

Caldeira, K., Rampino, M.R., Volk, T., and Zachos, J.C., 1990. Biogeochemical modeling at mass extinction boundaries: atmospheric carbon dioxide and ocean alkalinity at the K/T boundary. In Walliser, O.H., and Kauffman, E. (Eds.), Extinction Events in Earth History. Lect. Notes Earth Sci., 30:333-345. doi:10.1007/BFb0011156

Cande, S.C., and Kent, D.V., 1995. Revised calibration of the geomagnetic polarity timescale for the Late Cretaceous and Cenozoic. J. Geophys. Res., 100(B4):60936096. doi:10.1029/94JB03098

Coxall, H.K., D'Hondt, S., and Zachos, J.C., 2006. Pelagic evolution and environmental recovery after the Cretaceous-Paleogene mass extinction. Geology, 34(4):297300. doi:10.1130/G21702.1

Coxall, H.K., Wilson, P.A., Pälike, H., Lear, C.H., and Backman, J., 2005. Rapid stepwise onset of Antarctic glaciation and deeper calcite compensation in the Pacific Ocean. Nature (London, U. K.), 433(7021):53-57. doi:10.1038/nature03135

Culver, S.J., 2003. Benthic foraminifera across the Cretaceous-Tertiary (K-T) boundary: a review. Mar. Micropaleontol., 47(3-4):177-226. doi:10.1016/S03778398(02)00117-2

D’Hondt, S., Donaghay, P., Zachos, J.C., Luttenberg, D., and Lindinger, M., 1998. Organic carbon fluxes and ecological recovery from the Cretaceous-Tertiary mass extinction. Science, 282(5387):276-279. doi:10.1126/science.282.5387.276

D'Hondt, S., and Keller, G., 1991. Some patterns of planktic foraminiferal assemblage turnover at the Cretaceous Tertiary boundary. Mar. Micropaleontol., 17(1-2):77-118. doi:10.1016/0377-8398(91)90024-Z

D'Hondt, S., King, J., and Gibson, C., 1996. Oscillatory marine response to the Cretaceous-Tertiary impact. Geology, 24(7):611-614. doi:10.1130/0091-7613(1996) 024<0611:OMRTTC>2.3.CO;2

de Ruijter, W.P.M., Brummer, G.-J.A., Drijfhout, S.S., Lutjeharms, J.R.E., Peeters, F., Ridderinkhof, H., van Aken, H., and van Leeuwen, P.J., 2006. Observations of the inter-ocean exchange around South Africa. Eos, Trans. Am. Geophys. Union, 87(9):97. doi:10.1029/2006E0090002

DeConto, R.M., and Pollard, D., 2003. Rapid Cenozoic glaciation of Antarctica induced by declining atmospheric $\mathrm{CO}_{2}$. Nature (London, U. K.), 421(6920):245-249. doi:10.1038/nature01290

Dickens, G.R., 2000. Methane oxidation during the late Palaeocene Thermal Maximum. Bull. Soc. Geol. Fr., 171:37-49.

Dickens, G.R., Castillo, M.M., and Walker, J.C.G., 1997. A blast of gas in the latest Paleocene: simulating first-order effects of massive dissociation of oceanic methane hydrate. Geology, 25(3):259-262. doi:10.1130/0091-7613(1997)025<0259: ABOGIT>2.3.CO;2

Dickens, G.R., O'Neil, J.R., Rea, D.K., and Owen, R.M., 1995. Dissociation of oceanic methane hydrate as a cause of the carbon isotope excursion at the end of the Paleocene. Paleoceanography, 10(6):965-972. doi:10.1029/95PA02087

Diester-Haass, L., and Billups, K., 2005. Miocene global carbon isotope shifts and marine biological productivity. Eos, Trans. Am. Geophys. Union, 86(52)(Suppl.):PP51B0588. (Abstract) 
Fischer, G., Wefer, G., Romero, O., Dittert, N., Ratmeyer, V., and Donner, B., 2003. Transfer of particles into the deep Atlantic and the global ocean: control of nutrient supply and ballast production. In Wefer, G., Mulitza, S., and Ratmeyer, V. (Eds.), The South Atlantic in the Late Quaternary: Reconstruction of Material Budgets and Current Systems: Berlin (Springer-Verlag), 21-46.

Gibbs, S.J., Bown, P.R., Sessa, J.A., Bralower, T.J., and Wilson, P.A., 2006. Nannoplankton extinction and origination across the Paleocene-Eocene Thermal Maximum. Science, 314(5806):1770-1773. doi:10.1126/science.1133902

Gradstein, F.M., Ogg, J.G., and Smith, A. (Eds.), 2004. A Geologic Time Scale 2004: Cambridge (Cambridge Univ. Press).

Hallock, P., Premoli Silva, I., and Boersma, A., 1991. Similarities between planktonic and larger foraminiferal evolutionary trends through Paleogene paleoceanographic changes. Palaeogeogr., Palaeoclimatol., Palaeoecol., 83(1-3):49-64. doi:10.1016/ 0031-0182(91)90075-3

Hambrey, M.J., Ehrmann, W.U., and Larsen, B., 1991. Cenozoic glacial record of the Prydz Bay continental shelf, East Antarctica. In Barron, J., Larsen, B., et al., Proc. ODP, Sci. Results, 119: College Station, TX (Ocean Drilling Program), 77-132. doi:10.2973/odp.proc.sr.119.200.1991

Harzhauser, M., Piller, W.E., and Steininger, F.F., 2002. Circum-Mediterranean OligoMiocene biogeographic evolution-the gastropods' point of view. Palaeogeogr., Palaeoclimatol., Palaeoecol., 183(1-2):103-133. doi:10.1016/S0031-0182(01)00464-3

Hathorne, E.C., and James, R.H., 2006. Temporal record of lithium in seawater: a tracer for silicate weathering? Earth Planet. Sci. Lett., 246(3-4):393-406. doi:10.1016/j.epsl.2006.04.020

Herbert, T.D., and D'Hondt, S.L., 1990. Precessional climate cyclicity in Late Cretaceous-early Tertiary marine sediments: a high resolution chronometer of Cretaceous/Tertiary boundary events. Earth Planet. Sci. Lett., 99(3):263-275. doi:10.1016/0012-821X(90)90115-E

Herguera, J.C., and Berger, W.H., 1991. Paleoproductivity from benthic foraminifera abundance: glacial to postglacial change in the west-equatorial Pacific. Geology, 19(12):1173-1176. doi:10.1130/0091-7613(1991)019<1173:PFBFAG >2.3.CO;2

Hsü, K.J., LaBrecque, J.L., et al., 1984. Init. Repts. DSDP, 73: Washington (U.S. Govt. Printing Office).

Hsü, K.J., He, Q., McKenzie, J.A., Weissert, H., Perch-Nielsen, K., Oberhänsli, H., Kelts, K., LaBrecque, J., Tauxe, L., Krähenbühl, U., Percival, S.F., Wright, R., Karpoff, A.M., Petersen, N., Tucker, P., Poore, R.Z., Gombos, A.M., Pisciotto, K., Carman, Jr., M.F., and Schreiber, E., 1982. Mass mortality and its environmental and evolutionary consequences. Science, 216(4543):249-256. doi:10.1126/science.216.4543.249

Hsü, K.J., and Weissert, H.J. (Eds.), 1985. South Atlantic Paleoceanography: Cambridge (Cambridge Univ. Press).

Jones, C.E., and Jenkyns, H.C., 2001. Seawater strontium isotopes, oceanic anoxic events, and seafloor hydrothermal activity in the Jurassic and Cretaceous. Am.J. Sci., 301(2):112-149. doi:10.2475/ajs.301.2.112

Kelly, D.C., 2002. Response of Antarctic (ODP Site 690) planktonic foraminifera to the Paleocene-Eocene Thermal Maximum: faunal evidence for ocean/climate change. Paleoceanography, 17(4):1071. doi:10.1029/2002PA000761

Kelly, D.C., Bralower, T.J., and Zachos, J.C., 1998. Evolutionary consequences of the Latest Paleocene Thermal Maximum for tropical planktonic foraminifera. Palaeogeogr., Palaeoclimatol., Palaeoecol., 141(1-2):139-161. doi:10.1016/S0031-0182(98)00017-0

Kennett, J.P., and Shackleton, N.J., 1976. Oxygen isotopic evidence for the development of the psychrosphere $38 \mathrm{Myr}$ ago. Nature (London, U. K.), 260(5551):513-515. doi:10.1038/260513a0

Kennett, J.P., and Stott, L.D., 1991. Abrupt deep-sea warming, paleoceanographic changes and benthic extinctions at the end of the Palaeocene. Nature (London, $U$. K.), 353(6341):225-229. doi:10.1038/353225a0 
Koch, P.L., Zachos, J.C., and Dettman, D.L., 1995. Stable isotope stratigraphy and palaeoclimatology of the Palaeogene Bighorn Basin (Wyoming, USA). Palaeogeogr., Palaeoclimatol., Palaeoecol., 115(1-4):61-89. doi:10.1016/0031-0182(94)00107-J

Koch, P.L., Zachos, J.C., and Gingerich, P.D., 1992. Correlation between isotope records in marine and continental carbon reservoirs near the Palaeocene/Eocene boundary. Nature (London, U. K.), 358:319-322. doi:10.1038/358319a0

Kroon, D., Dickens, G., Erbacher, J., Herbert, T., Jansa, L., Jenkyns, H., Kaiho, K., Kent, D., Leckie, M., Norris, R., Premoli-Silva, I., Zachos, J., and Bassinot, F., 2000. Excerpts from the final report of the JOIDES Extreme Climates Program. JOIDES J., 26(1):17-28.

Kump, L.R., 1991. Interpreting carbon-isotope excursions: Strangelove oceans. Geology, 19(4):299-302. doi:10.1130/0091-7613(1991)019<0299:ICIESO>2.3.CO;2

Laskar, J., Robutel, P., Joutel, F., Gastineau, M., Correia, A.C.M., and Levrard, B., 2004. A long-term numerical solution for the insolation quantities of the Earth. Astron. Astrophys., 428(1):261-285. doi:10.1051/0004-6361:20041335

Liu, Z., Tuo, S., Zhao, Q., and Chen, X., 2004a. Marine carbonate dissolution event across the Eocene/Oligocene boundary: the Walvis Ridge transect, South Atlantic (ODP Leg 208). Eos, Trans. Am. Geophys. Union, 85(47)(Suppl.):PP11B-0571. (Abstract)

Liu, Z., Tuo, S., Zhao, Q., Cheng, X, and Huang, W., 2004b. Deep-water Earliest Oligocene Glacial Maximum (EOGM) in South Atlantic. Chin. Sci. Bull., 49(20):21902197. doi:10.1360/04wd0228

Lourens, L.J., Sluijs, A., Kroon, D., Zachos, J.C., Thomas, E., Röhl, U., Bowles, J., and Raffi, I., 2005. Astronomical pacing of late Palaeocene to early Eocene global warming events. Nature (London, U. K.), 435(7045):1083-1087. doi:10.1038/ nature03814

Luterbacher, H.P., and Premoli Silva, I., 1964. Biostratigrafia del limite Cretaceo-Terziario nell' Appennino centrale. Riv. Ital. Paleontol., 70:67-117.

Lyle, M., Wilson, P.A., Janecek, T.R., et al., 2002. Proc. ODP, Init. Repts., 199: College Station, TX (Ocean Drilling Program). doi:10.2973/odp.proc.ir.199.2002

Mikolajewicz, U., Maier-Reimer, E., Crowley, T.J., and Kim, K.-Y., 1993. Effect of Drake and Panamanian gateways on the circulation of an ocean model. Paleoceanography, 8:409-426.

Miller, K.G., Janecek, T.R., Katz, M.E., and Keil, D.J., 1987. Abyssal circulation and benthic foraminiferal changes near the Paleocene/Eocene boundary. Paleoceanography, 2:741-761.

Miller, K.G., and Katz, M.E., 1987. Oligocene to Miocene benthic foraminiferal and abyssal circulation changes in the North Atlantic. Micropaleontology, 33(2):97-149. doi: $10.2307 / 1485489$

Miller, K.G., Mountain, G.S., Browning, J.V., Kominz, M., Sugarman, P.J., ChristieBlick, N., Katz, M.E., and Wright, J.D., 1998. Cenozoic global sea level, sequences, and the New Jersey transect: results from coastal plain and continental slope drilling. Rev. Geophys., 36(4):569-602. doi:10.1029/98RG01624

Miller, K.G., Wright, J.D., and Fairbanks, R.G., 1991. Unlocking the ice house: Oligocene-Miocene oxygen isotopes, eustasy, and margin erosion. J. Geophys. Res., 96:6829-6848.

Monechi, S., 1985. Campanian to Pleistocene calcareous nannofossil stratigraphy from the northwest Pacific Ocean, Deep Sea Drilling Project Leg 86. In Heath, G.R., Burckle, L.H., et al., Init. Repts. DSDP, 86: Washington (U.S. Govt. Printing Office), 301-336.

Monechi, S., Angori, E., and von Salis, K., 2000. Calcareous nannofossil turnover around the Paleocene/Eocene transition at Alamedilla (southern Spain). Bull. Soc. Geol. Fr., 171:477-489.

Moore, Jr., T.C., Rabinowitz, P.D., et al., 1984. Init. Repts. DSDP, 74: Washington, D.C. (U.S. Govt. Printing Office). 
Nisancioglu, K.H., Raymo, M.E., and Stone, P.H., 2003. Reorganization of Miocene deep water circulation in response to the shoaling of the Central American Seaway. Paleoceanography, 18(1):1006. doi:10.1029/2002PA000767

Norris, R.D., Huber, B.T., and Self-Trail, J., 1999. Synchroneity of the K-T oceanic mass extinction and meteorite impact: Blake nose, western North Atlantic. Geology, 27(5):419-422. doi:10.1130/0091-7613(1999)027<0419:SOTKTO>2.3.CO;2

Norris, R.D., and Röhl, U., 1999. Carbon cycling and chronology of climate warming during the Palaeocene/Eocene transition. Nature (London, U. K.), 401(6755):775778. doi:10.1038/44545

Oglesby, R.J., 1991. Joining Australia to Antarctica: GCM implications for the Cenozoic record of Antarctic glaciation. Clim. Dynam., 6(1):13-22. doi:10.1007/ BF00210578

Pagani, M., Pedentchouk, N., Huber, M., Sluijs, A., Schouten, S., Brinkhuis, H., Sinninghe Damsté, J.S., Dickens, G.R., and Expedition 302 Scientists, 2006. Arctic hydrology during global warming at the Palaeocene/Eocene Thermal Maximum. Nature (London, U. K.), 443(7103):671-675. doi:10.1038/nature05043

Paytan, A., Kastner, M., Campbell, D., and Thiemens, M.H., 1998. Sulfur isotopic composition of Cenozoic seawater sulfate. Science, 282(5393):1459-1462. doi:10.1126/science.282.5393.1459

Pearson, P.N., and Palmer, M.R., 2000. Atmospheric carbon dioxide concentrations over the past 60 million years. Nature (London, U. K.), 406(6979):695-699. doi:10.1038/35021000

Petrizzo, M.R., 2005. An early late Paleocene event on Shatsky Rise, northwest Pacific Ocean (ODP Leg 198): evidence from planktonic foraminiferal assemblages. In Bralower, T.J., Premoli Silva, I., and Malone, M.J. (Eds.), Proc. ODP, Sci. Results, 198: College Station, TX (Ocean Drilling Program), 1-29. doi:10.2973/ odp.proc.sr.198.102.2005

Raffi, I., Backman, J., and Pälike, H., 2005. Changes in calcareous nannofossil assemblages across the Paleocene/Eocene transition from the paleo-equatorial Pacific Ocean. Palaeogeogr., Palaecoclimatol., Palaeoecol., 226(1-2):93-126. doi:10.1016/ j.palaeo.2005.05.006

Raymo, M.E., Ruddiman, W.F., Shackleton, N.J., and Oppo, D.W., 1990. Evolution of Atlantic-Pacific $\delta^{13} \mathrm{C}$ gradients over the last 2.5 m.y. Earth Planet. Sci. Lett., 97(34):353-368. doi:10.1016/0012-821X(90)90051-X

Rea, D.K., 1994. The paleoclimatic record provided by eolian deposition in the deep sea: the geologic history of wind. Rev. Geophys., 32(2):159-196. doi:10.1029/ 93RG03257

Rea, D.K., and Hovan, S.A., 1995. Grain size distribution and depositional processes of the mineral component of abyssal sediments: lessons from the North Pacific. Paleoceanography, 10(2):251-258. doi:10.1029/94PA03355

Rind, D., and Chandler, M., 1991. Increased ocean heat transport and warmer climate. J. Geophys. Res., 96:7437-7461.

Robert, C., and Kennett, J.P., 1997. Antarctic continental weathering changes during Eocene-Oligocene cryosphere expansion: clay mineral and oxygen isotope evidence. Geology, 25(7):587-590. doi:10.1130/0091-7613(1997)025<0587:ACWCDE>2.3.CO;2

Röhl, U., Bralower, T.J., Norris, R.D., and Wefer, G., 2000. New chronology for the Late Paleocene Thermal Maximum and its environmental implications. Geology, 28(10):927-930. doi:10.1130/0091-7613(2000)028<0927:NCFTLP>2.3.CO;2

Röhl, U., Norris, R.D., and Ogg, J.G., 2003. Cyclostratigraphy of upper Paleocene and late Eocene sediments at Blake Nose Site 1051 (western North Atlantic). In Gingerich, P., Schmitz, B., and Thomas, E. (Eds.), Causes and Consequences of Globally Warm Climates in the Early Paleogene. Spec. Pap.-Geol. Soc. Am., 369:567-589.

Röhl, U., Ogg, J.G., Geib, T.L., and Wefer, G., 2001. Astronomical calibration of the Danian time scale. In Kroon, D., Norris, R.D., and Klaus, A. (Eds.), Western North Atlantic Paleogene and Cretaceous Paleoceanography. Geol. Soc. Spec. Publ., 183:163184. 
Röhl, U., Westerhold, T., Bralower, T.J., Petrizzo, M.-R., and Zachos, J.C., 2004. An early late Paleocene global dissolution event and new constraints for an astronomically-tuned early Paleogene time scale [ICP VIII, 8th International Conference on Paleoceanography, Biarritz, France, 5-10 September, 2004]. (Abstract)

Röhl, U., Westerhold, T., Bralower, T.J., and Zachos, J.C., 2006. Status of the duration of the Paleocene-Eocene Thermal Maximum (PETM). In Caballero, F., Apellaniz, E., Baceta, J.I., Bernaola, G., Orue-Etxebarria, X., Payros, A., and Pujalte, V. (Eds.), Climate and Biota of the Early Paleogene, Bilbao 2006: Bilbao (Univ. Basque Country), 112.

Röhl, U., Westerhold, T., Monechi, S., Thomas, E., Zachos, J.C., and Donner, B., 2005. The third and final early Eocene thermal maximum: characteristics, timing, and mechanisms of the "X" event. Geol. Soc. Am. Abstr. Programs, 37(7):264.

Salamy, K.A., and Zachos, J.C., 1999. Latest Eocene-early Oligocene climate change and Southern Ocean fertility: inferences from sediment accumulation and stable isotope data. Palaeogeogr., Palaeoclimatol., Palaeoecol., 145(1-3):61-77. doi:10.1016/ S0031-0182(98)00093-5

Sarmiento, J.L., Gruber, N., Brzezinski, M.A., and Dunne, J.P., 2004. High-latitude controls of thermocline nutrients and low latitude biological productivity. Nature (London, U. K.), 427(6969):56-60. doi:10.1038/nature02127

Schmitz, B., Charisi, S.D., Thompson, E.I., and Speijer, R.P., 1997. Barium, $\mathrm{SiO}_{2}$ (excess), and $\mathrm{P}_{2} \mathrm{O}_{5}$ as proxies of biological productivity in the Middle East during the Palaeocene and the latest Palaeocene benthic extinction event. Terra Nova, 9(2):95-99. doi:10.1111/j.1365-3121.1997.tb00011.x

Schulz, M., Berger, W.H., Sarnthein, M., and Grootes, P.M., 1999. Amplitude variations of 1470-year climate oscillations during the last 100,000 years linked to fluctuations of continental ice mass. Geophys. Res. Lett., 26(22):3385-3388. doi:10.1029/1999GL006069

Shackleton, N.J., 1987. The carbon isotope record of the Cenozoic: history of organic carbon burial and of oxygen in the ocean and atmosphere. In Brooks, J., and Fleet, A.J. (Eds.), Marine Petroleum Source Rocks. Geol. Soc. Spec. Publ., 26:423-434.

Sijp, W.P., and England, M.H., 2004. Effect of the Drake Passage throughflow on global climate. J. Phys. Oceanogr., 34(5):1254-1266. doi:10.1175/1520-0485(2004)034 $<$ 1254:EOTDPT>2.0.CO;2

Sloan, L.C., and Barron, E.J., 1992. A comparison of Eocene climate model results to quantified paleoclimatic interpretations. Palaeogeogr., Palaeoclimatol., Palaeoecol., 93(3-4):183-202. doi:10.1016/0031-0182(92)90096-N

Sloan, L.C., and Rea, D.K., 1996. Atmospheric carbon dioxide and early Eocene climate: a general circulation modeling sensitivity study. Palaeogeogr., Palaeoclimatol., Palaeoecol., 119(3-4):275-292. doi:10.1016/0031-0182(95)00012-7

Sloan, L.C., Walker, J.C.G., Moore, T.C., Rea, D.K., and Zachos, J.C., 1992. Possible methane-induced polar warming in the early Eocene. Nature (London, U. K.), 357(6376):320-322. doi:10.1038/357320a0

Sloan, L.C., Walker, J.C.G., and Moore, Jr., T.C., 1995. Possible role of oceanic heat transport in early Eocene climate. Paleoceanography, 10(2):347-356. doi:10.1029/ 94PA02928

Smart, C.W., 1992. Early to middle Miocene benthic foraminiferal faunas from DSDP Sites 518 and 529, South Atlantic: preliminary investigations. In Takayanagi, Y., and Saito, T. (Eds.), Studies in Benthic Foraminifera: Proc. 4th Int. Symp. Benthic Foraminifera: Sendai, Japan (Tokai Univ. Press), 245-248.

Smart, C.W., and Murray, J.W., 1994. An early Miocene Atlantic-wide foraminiferal/ palaeoceanographic event. Palaeogeogr., Palaeoclimatol., Palaeoecol., 108(1-2):139_ 148. doi:10.1016/0031-0182(94)90026-4

Smart, C.W., and Ramsay, A.T.S., 1995. Benthic foraminiferal evidence for the existence of an early Miocene oxygen-depleted oceanic water mass? J. Geol. Soc. (London, U. K.), 152:735-738. 
Smart, C.W., and Thomas, E., 2006. The enigma of early Miocene biserial planktic foraminifera. Geology, 34(12):1041-1044. doi:10.1130/G23038A.1

Spiess, V., Krastel, S., Beitler, B., Böke, W., Gerriets, A., Heidersdorf, F., Leupold, J., Salem, M., Schruöter, F., Schwenk, T., Zahn-Knoll, R., and Zuhisdorff, L., 2003. Report and preliminary results of Meteor Cruise M49/1 Cape Town (South Africa)Montevideo (Uruguay) 04.01.2000-10.02.2000. Ber., Fachbereich Geowiss., Univ. Bremen, 205:57.

Stott, L.D., and Kennett, J.P., 1989. New constraints on early Tertiary palaeoproductivity from carbon isotopes in foraminifera. Nature (London, U. K.), 342(6249):526529. doi:10.1038/342526a0

Stott, L.D., Kennett, J.P., Shackleton, N.J., and Corfield, R.M., 1990. The evolution of Antarctic surface waters during the Paleogene: inferences from the stable isotopic composition of planktonic foraminifers, ODP Leg 113. In Barker, P.F., Kennett, J.P., et al., Proc. ODP, Sci. Results, 113: College Station, TX (Ocean Drilling Program), 849-863. doi:10.2973/odp.proc.sr.113.187.1990

Thierstein, H.R., 1982. Terminal Cretaceous plankton extinctions: a critical assessment. In Silver, L.T., and Schultz, P.H. (Eds.), Geological Implications of Impacts of Large Asteroids and Comets on the Earth. Spec. Pap.-Geol. Soc. Am., 190:385-399.

Thomas, D.J., Bralower, T.J., and Jones, C.E., 2003. Neodymium isotopic reconstruction of late Paleocene-early Eocene thermohaline circulation. Earth Planet. Sci. Lett., 209(3-4):309-322. doi:10.1016/S0012-821X(03)00096-7

Thomas, D.J., Bralower, T.J., and Zachos, J.C., 1999. New evidence for subtropical warming during the Late Paleocene Thermal Maximum: stable isotopes from Deep Sea Drilling Project Site 527, Walvis Ridge. Paleoceanography, 14(5):561-570. doi:10.1029/1999PA900031

Thomas, E., 1985. Late Eocene to Recent deep-sea benthic foraminifers from the central equatorial Pacific Ocean. In Mayer, L., Theyer, F., Thomas, E., et al., Init. Repts. DSDP, 85: Washington (U.S. Govt. Printing Office), 655-694.

Thomas, E., 1986. Early to middle Miocene benthic foraminiferal faunas from DSDP Sites 608 and 610, North Atlantic. In Summerhayes, C.P., and Shackleton, N.J. (Eds.), North Atlantic Palaeoceanography. Geol. Soc. Spec. Publ., 21:205-218.

Thomas, E., 1987. Late Oligocene to Recent foraminifers from Deep Sea Drilling Project Sites 608 and 610, northeastern North Atlantic. In Ruddimann, W.F., Kidd, R.B., Thomas, E., et al., Init. Repts. DSDP, 94: Washington (U.S. Govt. Printing Office), 997-1031.

Thomas, E., 1990. Late Cretaceous-early Eocene mass extinctions in the deep sea. In Sharpton, V.L., and Ward, P.D. (Eds.), Global Catastrophes in Earth History: An Interdisciplinary Conference on Impacts, Volcanism, and Mass Mortality. Spec. Pap.-Geol. Soc. Am., 247:481-495.

Thomas, E., 1998. Biogeography of the late Paleocene benthic foraminiferal extinction. In Aubry, M.-P., Lucas, S.G., and Berggren, W.A. (Eds.), Late Paleocene-Early Eocene Biotic and Climatic Events in the Marine and Terrestrial Records: New York (Columbia Univ. Press), 214-243.

Thomas, E., in press. Cenozoic mass extinctions in the deep sea; what disturbs the largest habitat on Earth? Monechi, S., Coccioni, R., and Rampino, M. (Eds.), Large Exosystem Perturbations: Causes and Consequences? Spec. Pap.-Geol. Soc. Am., 424.

Thomas, E., and Gooday, A.J., 1996. Cenozoic deep-sea benthic foraminifers: tracers for changes in oceanic productivity? Geology, 24(4):355-358. doi:10.1130/00917613(1996)024<0355:CDSBFT>2.3.CO;2

Thomas, E., and Shackleton, N., 1996. The Palaeocene-Eocene benthic foraminiferal extinction and stable isotope anomalies. In Knox, R.W.O'B., Corfield, R.M., and Dunay, R.E. (Eds.), Correlation of the Early Paleogene in Northwest Europe. Geol. Soc. Spec. Publ., 101:401-441.

Thomas, E., Zachos, J.C., and Bralower, T.J., 2000. Deep-sea environments on a warm earth: latest Paleocene-early Eocene. In Huber, B.T., MacLeod, K.G.E., and Wing, 
S.L.E. (Eds.), Warm Climates in Earth History: Cambridge (Cambridge Univ. Press), 132-160.

Thunell, R.C., and Corliss, B.H., 1986. Late Eocene-early Oligocene carbonate sedimentation in the deep sea. In Pomerol, C., and Premoli Silva, I. (Eds.), Terminal Eocene Events. Dev. Palaeontol. Stratigr., 9:363-380.

Tremolada, F., and Bralower, T.J., 2004. Nannofossil assemblage fluctuations during the Paleocene-Eocene Thermal Maximum at Sites 213 (Indian Ocean) and 401 (North Atlantic Ocean): paleoceanographic implications. Mar. Micropaleontol., 52(1-4):107-116. doi:10.1016/j.marmicro.2004.04.002

Varadi, F., Runnegar, B., and Ghil, M., 2003. Successive refinements in long-term integrations of planetary orbits. Astrophys. J., 592(1):620-630. doi:10.1086/375560

Via, R.K., and Thomas, D.J., 2006. Evolution of Atlantic thermohaline circulation: early Oligocene onset of deep-water production in the North Atlantic. Geology, 34(6):441-444. doi:10.1130/G22545.1

Weijer, W., de Ruijter, W.P.M., Dijkstra, H.A., and van Leeuwen, P.J., 1999. Impact of interbasin exchange on the Atlantic overturning circulation. J. Phys Oceanogr., 29(9):2266-2284. doi:10.1175/1520-0485(1999)029<2266:IOIEOT>2.0.CO;2

Westerhold, T., Röhl, U., Laskar, J., Raffi, I., Bowles, J., Lourens, L.J., and Zachos, J.C., in press. On the duration of Magnetochrons C24r and C25n, and the timing of early Eocene global warming events: implications from the ODP Leg 208 Walvis Ridge depth transect. Paleoceanography.

Wing, S.L., 1998. Late Paleocene-early Eocene floral and climatic change in the Bighorn Basin, Wyoming. In Berggren, W.A., Aubrey, M.-P., and Lucas, S.G. (Eds.), Late Paleocene-Early Eocene Biotic and Climatic Events: New York (Columbia Univ. Press), 371-391.

Wing, S.L., Bao, H., and Koch, P.L., 2000. An early Eocene cool period? Evidence for continental cooling during the warmest part of the Cenozoic. In Huber, B.T., MacCleod, K., and Wing, S.L. (Eds.), Warm Climates in Earth History: Cambridge (Cambridge Univ. Press), 197-237.

Wright, J.D., 1998. The role of the Greenland-Scotland ridge in Cenozoic climate change. In Crowley, T.J., and Burke, K. (Eds.), Tectonic Boundary Conditions for Climate Reconstructions: New York (Oxford Univ. Press), 192-211.

Wright, J.D., and Miller, K.G., 1993. Southern Ocean influences on late Eocene to Miocene deep-water circulation. In Kennett, J.P., and Warnke, D.A. (Eds.), The Antarctic Paleoenvironment: A Perspective on Global Change. Antarct. Res. Ser., 60:1-25.

Wright, J.D., and Miller, K.G., 1996. Control of North Atlantic deep water circulation by the Greenland-Scotland Ridge. Paleoceanography, 11(2):157-170. doi:10.1029/ 95PA03696

Zachos, J.C., and Arthur, M.A., 1986. Paleoceanography of the Cretaceous/Tertiary boundary event: inferences from stable isotopic and other data. Paleoceanography, $1: 5-26$.

Zachos, J.C., Arthur, M.A., and Dean, W.E., 1989. Geochemical evidence for suppression of pelagic marine productivity at the Cretaceous/Tertiary boundary. Nature (London, U. K.), 337(6202):61-64. doi:10.1038/337061a0

Zachos, J.C., Breza, J.R., and Wise, S.W., 1992. Early Oligocene ice-sheet expansion on Antarctica: stable isotope and sedimentological evidence from Kerguelen Plateau, southern Indian Ocean. Geology, 20(6):569-573. doi:10.1130/0091-7613(1992)020 $<0569$ :EOISEO $>2.3 . \mathrm{CO} ; 2$

Zachos, J.C., Kroon, D., Blum, P., et al., 2004. Proc. ODP, Init. Repts., 208: College Station, TX (Ocean Drilling Program). doi:10.2973/odp.proc.ir.208.2004

Zachos, J.C., Lohmann, K.C., Walker, J.C.G., and Wise, Jr., S.W., 1993. Abrupt climate changes and transient climates during the Paleogene: a marine perspective. J. Geol., 101:191-213.

Zachos, J.C., Pagani, M., Sloan, L., Thomas, E., and Billups, K., 2001. Trends, rhythms, and aberrations in global climate 65 Ma to present. Science, 292(5517):686-693. doi:10.1126/science.1059412 
D. KROON ET AL.

Zachos, J.C., Quinn, R.M., and Salamy, K., 1996. High-resolution (104 yr) deep-sea foraminiferal stable isotope records of the Eocene-Oligocene climate transition. Paleoceanography, 11(3):251-266. doi:10.1029/96PA00571

Zachos, J.C., Röhl, U., Schellenberg, S.A., Sluijs, A., Hodell, D.A., Kelly, D.C., Thomas, E., Nicolo, M., Raffi, I., Lourens, L.J., McCarren, H., and Kroon, D., 2005. Rapid acidification of the ocean during the Paleocene-Eocene Thermal Maximum. Science, 308(5728):1611-1615. doi:10.1126/science.1109004

Zachos, J.C., Shackleton, N.J., Revenaugh, J.S., Pälike, H., and Flower, B.P., 2001. Periodic and non-periodic climate response to orbital forcing across the OligoceneMiocene boundary. Science, 292:274-277. doi:10.1126/science.1058288

Zachos, J.C., Stott, L.D., and Lohmann, K.C., 1994. Evolution of early Cenozoic marine temperatures. Paleoceanography, 9(2):353-387. doi:10.1029/93PA03266 


\section{KROON ET AL.}

Leg 208 Synthesis: Cenozoic Climate CyCles ANd Excursions

Figure F1. Bathymetric chart of Walvis Ridge and the South African margin, DSDP and ODP drill sites (Speiss et al., 2003).

Walvis Ridge

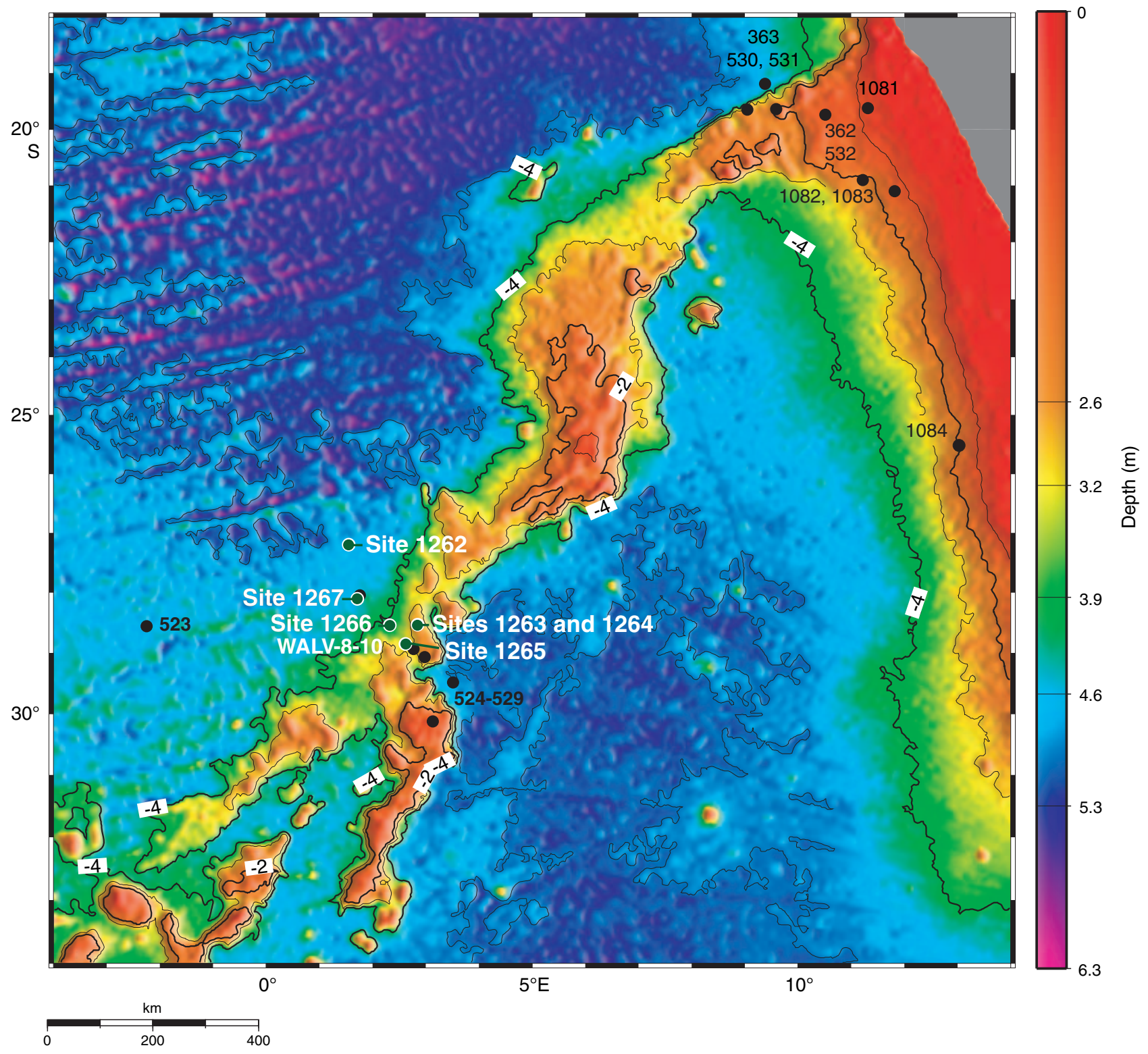




\section{KROON ET AL.}

Leg 208 Synthesis: Cenozoic Climate Cycles And Excursions

Figure F2. Study area of Meteor Cruise M49/1 and ODP Leg 208. Red lines = cruise track M49/1. Yellow lines $=$ seismic profiles with erosive structures (Bartels et al., this volume).

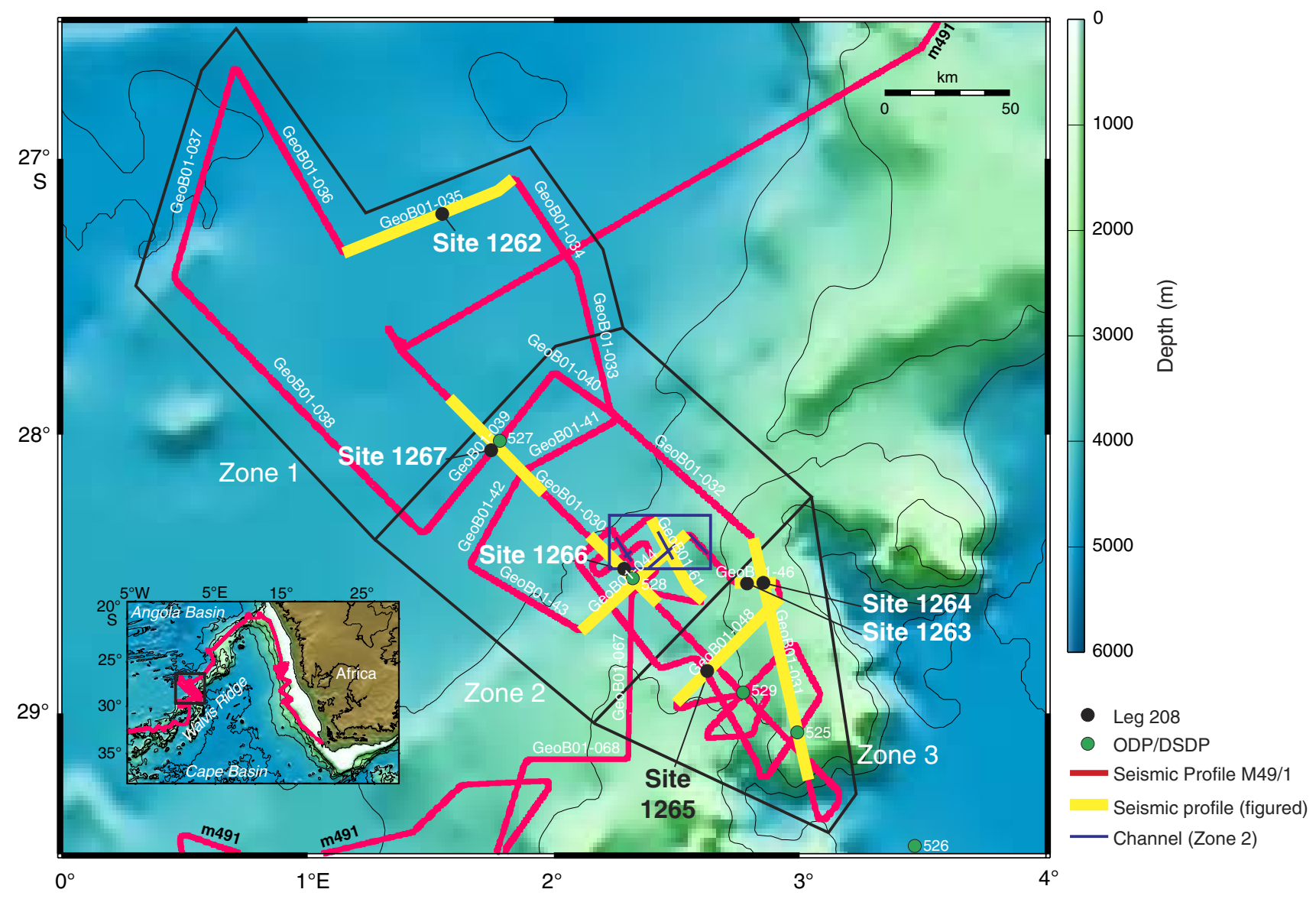


D. KROON ET AL.

Leg 208 Synthesis: Cenozoic Climate CyCles AND Excursions

Figure F3. Three-dimensional bathymetric chart of Walvis Ridge (Spiess et al., 2003).

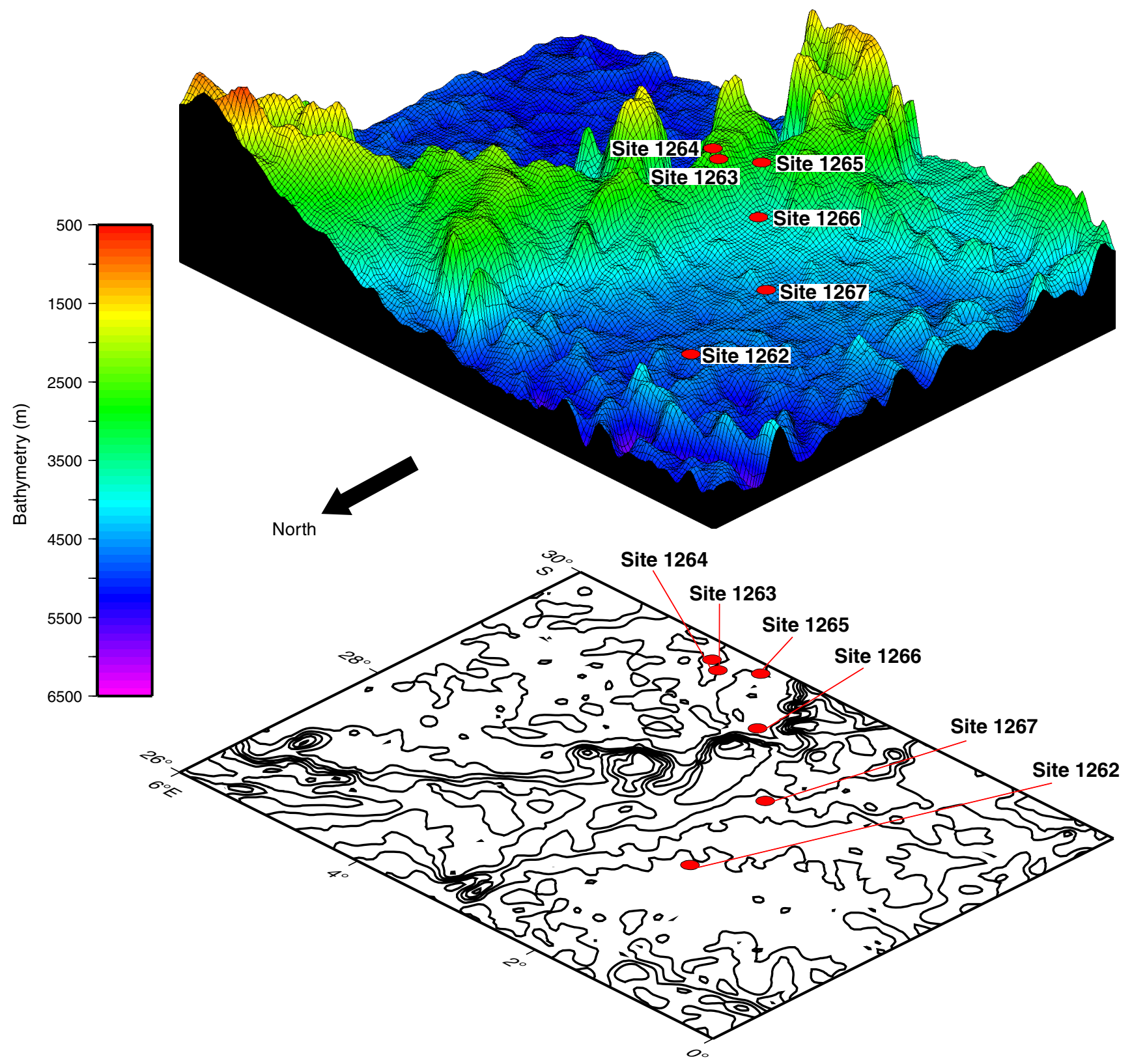




\section{KROON ET AL.}

Figure F4. Seismic profile crossing ODP Site 1262. A. GI gun data. B. High-resolution water gun data. Arrows indicate key layers: Elmo horizon, Paleocene/Eocene Thermal Maximum (PETM), Late Paleocene Biotic Event (ELPE) (Bartels et al., this volume). CMP = common midpoint, VE = vertical exaggeration.

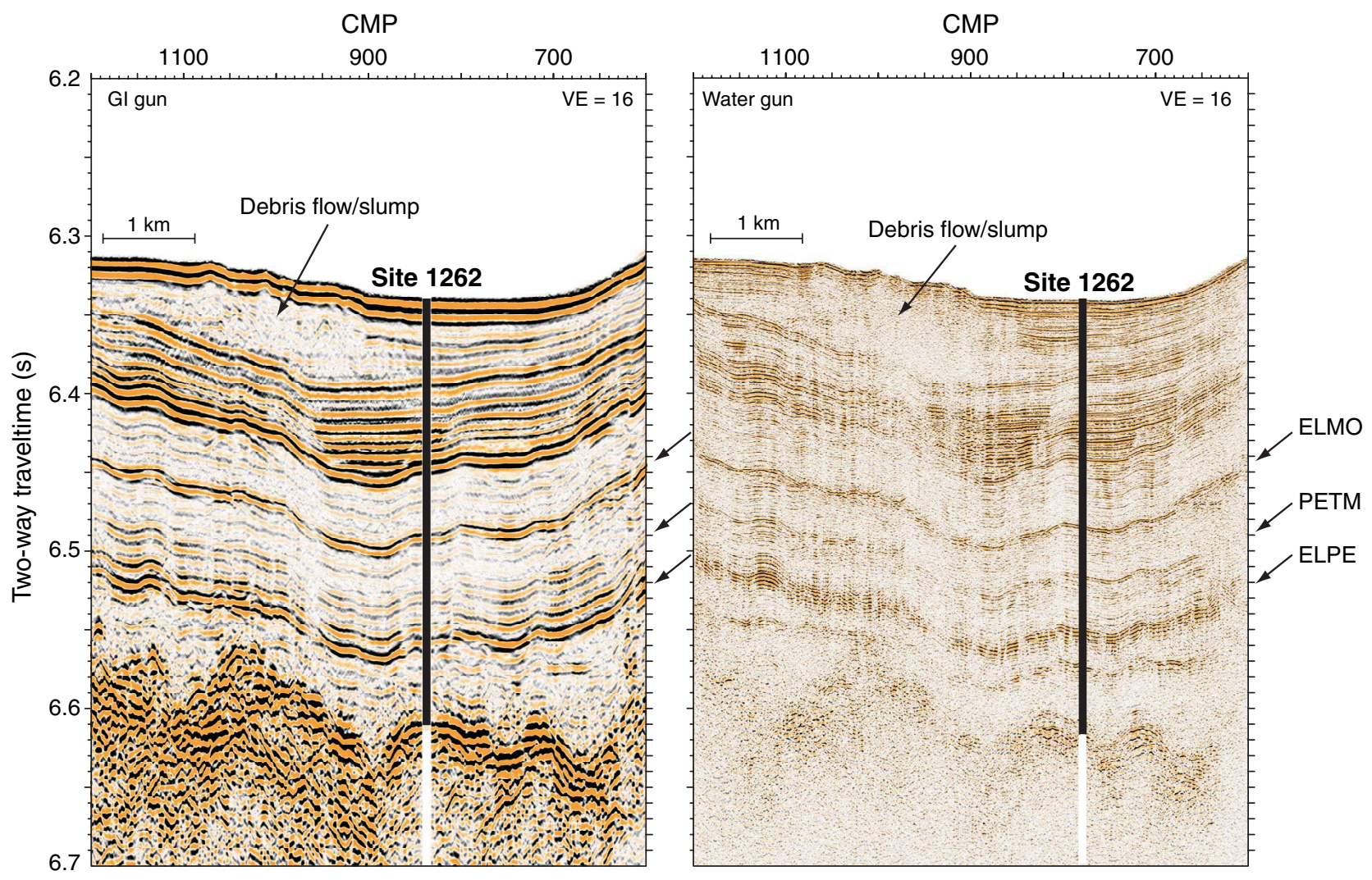




\section{KROON ET AL.}

Figure F5. Seismic Profile GeoB01-048, crossing a channel structure which might represent a path for bottom waters between the Cape Basin and the Angola Basin (Bartels et al., this volume). CDP = common depth point, $\mathrm{VE}=$ vertical exaggeration.

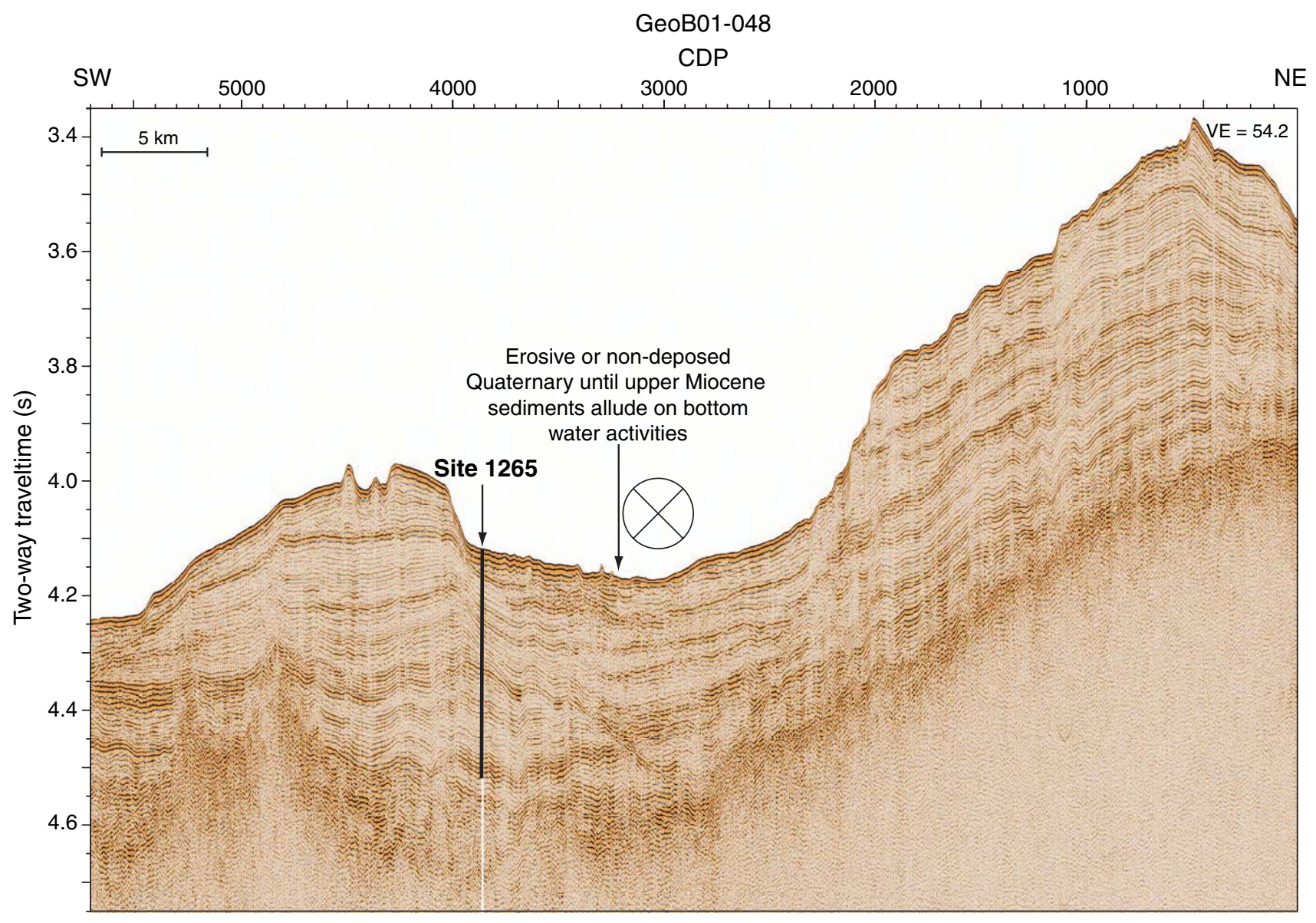




\section{KROON ET AL.}

Figure F6. Magnetostratigraphic interpretation for the Paleocene and Upper Cretaceous for Sites 1262, 1266 , and 1267. Depth for each site is given in mcd. Polarity column: black = normal, white = reverse, gray $=$ uncertain, $\mathrm{X}=$ no core recovery. Dashed correlations are approximate or uncertain. GPTS timescale of Cande and Kent (1995) is shown at left for reference. $\mathrm{P} / \mathrm{E}=$ Paleocene/Eocene boundary, $\mathrm{K} / \mathrm{T}=$ Cretaceous/ Tertiary boundary.

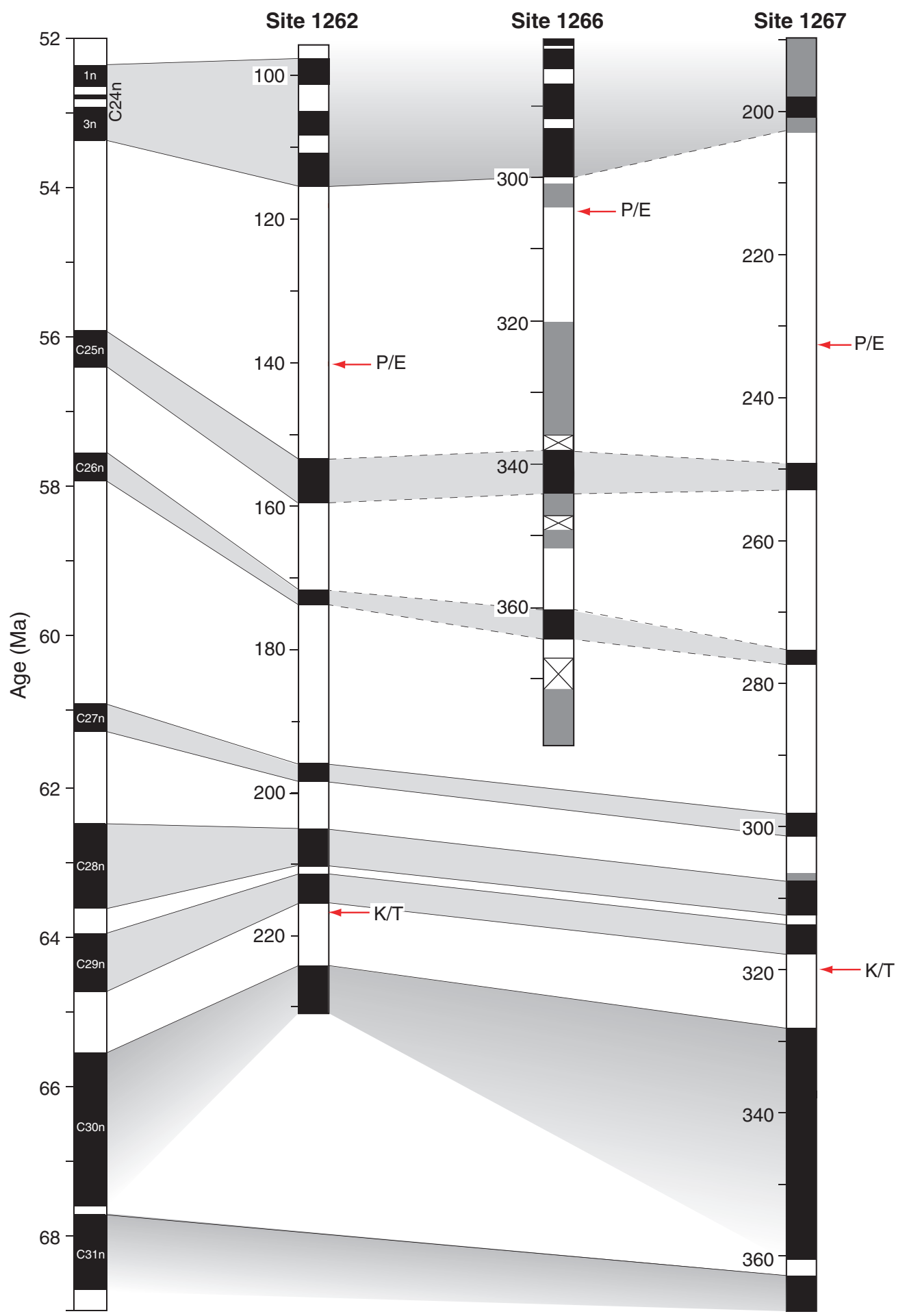




\section{KROON ET AL.}

Figure F7. Cycle counting of early Eocene and late Paleocene sediments at Walvis Ridge using color reflectance $a^{*}$ value (black plot) and high-resolution XRF Fe intensity data (red plot) (Sites 1262, 1263, and 1265). For each site the small black numbers indicate the number of precession cycles relative to the onset of the Paleocene/Eocene Thermal Maximum (PETM). The PETM (thick shaded bar) and the Elmo layer (thin shaded bar) are, according to precession cycle counting, 88 cycles apart; thus, the Elmo layer is labeled cycle 88. Short (green) and long (black) eccentricity cycles have been extracted by Gaussian filtering of the $\mathrm{a}^{*}$ value (Sites 1267 and 1265) and Fe intensity data (Sites 1262 and 1263). For Site 1262: filter frequency for the long eccentricity cycle $=0.19 \pm 0.057 \mathrm{cycles} / \mathrm{m}$; short eccentricity cycle $=0.80 \pm 0.24$ cycles $/ \mathrm{m}$. Site 1267 : long cycles $=0.15 \pm 0.045$ cycles $/ \mathrm{m}$; short $=0.66 \pm 0.20$ cycles $/ \mathrm{m}$. Site 1263 : long cycles $=0.10 \pm 0.03$ cycles/ $\mathrm{m}$; short $=0.41 \pm 0.123$ cycles $/ \mathrm{m}$. Site 1265 : long cycles $=0.12 \pm 0.036$ cycles $/ \mathrm{m}$; short $=0.46 \pm 0.138$ cycles $/$ $\mathrm{m}$. Green numbers indicate the short eccentricity maxima, where cycle 0 comprises the PETM; thus, the distance between the PETM and Elmo layer is 19 short eccentricity cycles. In addition, we labeled the long eccentricity maxima with roman numbers -VI to IV relative to the PETM. Eocene thermal maxima 1 (ETM1) and 2 (ETM-2) represent the PETM and Elmo, respectively. From Westerhold et al. (in press).

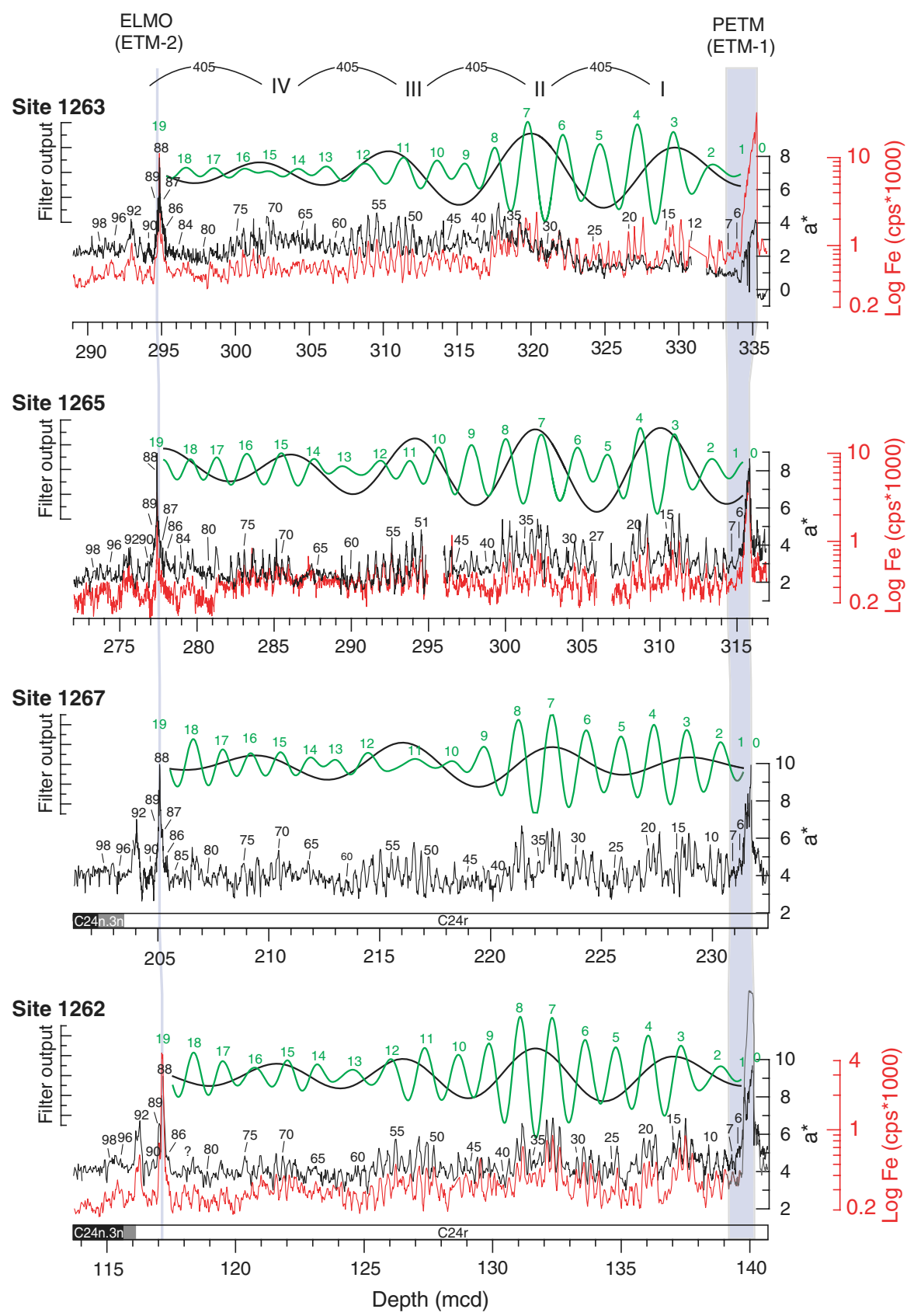




\section{KROON ET AL.}

Figure F8. Comparison of relative cycle counting timescale with present astronomical solutions for orbital eccentricity. A. Results of relative timescale. Site 1262 detrended Fe intensity data vs. relative cycle counting age. We assume that the mean duration of one precession cycle is 21.0 k.y., and we set the Elmo layer (ETM2) arbitrarily to $1.0 \mathrm{Ma}$. In contrast, the regions containing the Elmo layer and the Paleocene/Eocene Thermal Maximum (PETM; ETM-1) reveal lower than mean sedimentation rates due to strong dissolution of calcium carbonates (for discussion see Lourens et al., 2005; Zachos et al., 2005). B, C. Comparison of current astronomical solutions plotted against absolute time and the extracted amplitude modulation of Site 1262 data plotted against relative time. We shifted the Site 1262 data with respect to the best fit with the 405k.y. cycle. For further explanation see text. (B) Short eccentricity cycle amplitude modulation of Site 1262 Fe intensity, a*, La2004 (Laskar et al., 2004), and Va2003 (Varadi et al., 2003) orbital eccentricity solutions. For comparison, the La2004 and Va2003 amplitude modulations (AM) are plotted from 53 to $58 \mathrm{Ma}$ (lower plot) and 53.4 to $58.4 \mathrm{Ma}$ (middle plot). (C) Climatic precession cycle AM of Site 1262 data (Fe, $\mathrm{a}^{*}$ ) compared to orbital eccentricity solutions La2004 and Va2003 from 53 to $58 \mathrm{Ma}$ (lower plot) and 53.4 to 58.4 Ma (middle plot). Additionally, the 2.3-Ma eccentricity minima in Site 1262 data are marked (see text for discussion). AMs were extracted using the program Envelope (Schulz et al., 1999). -V through V = eccentricity maxima. GTS = geological timescale. ${ }^{*}=$ age onset of PETM (Wing et al., 2000), $\dagger=$ age onset of PETM GTS2004 (Gradstein et al., 2004), $\ddagger=$ recalibrated radiometric age estimate of PETM onset. From Westerhold et al. (in press).

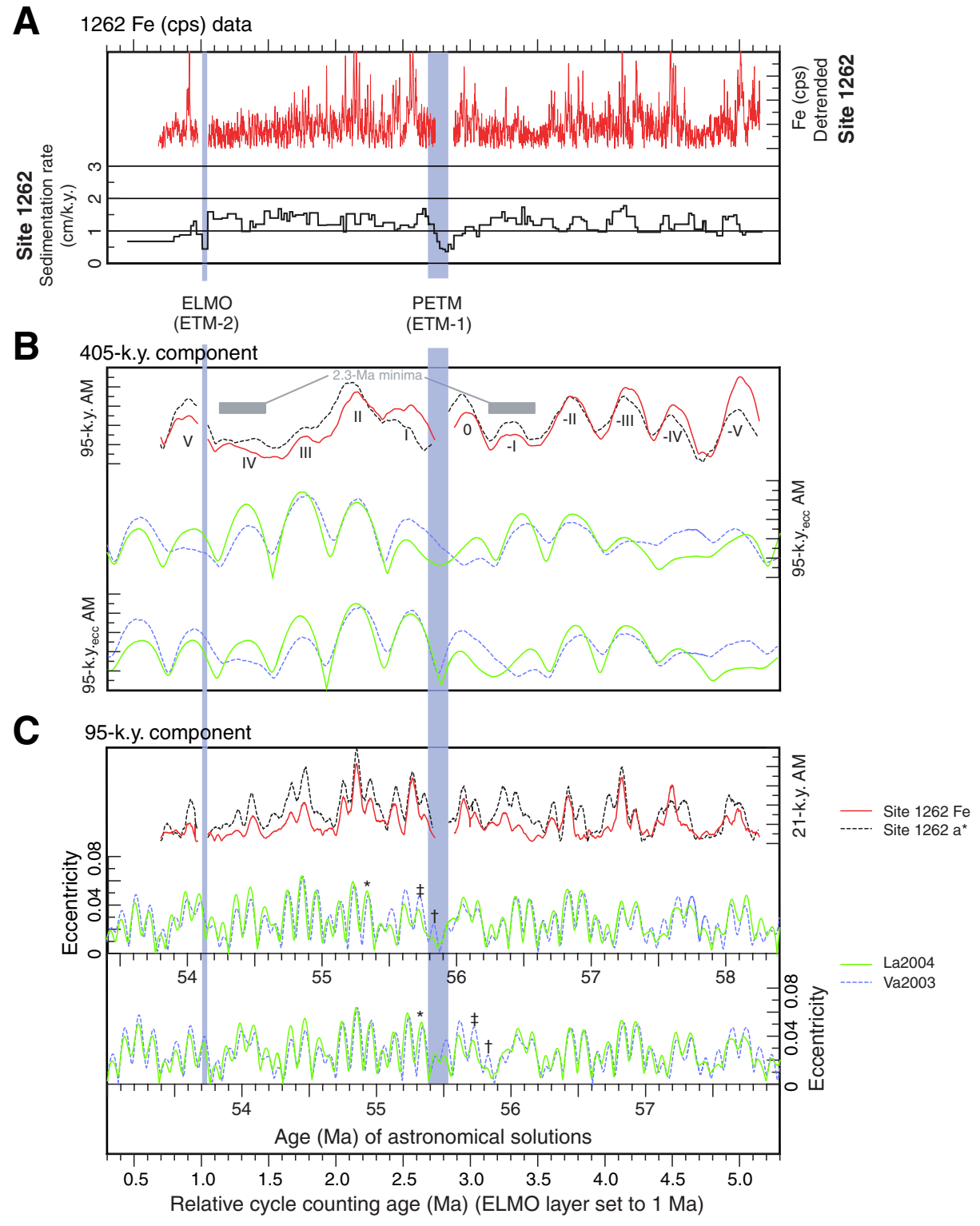




\section{KROON ET AL.}

Figure F9. The Cretaceous/Paleocene boundary from Walvis Ridge Holes 1262B, 1262C, 1267A, and 1267B. Strong changes in magnetic susceptibility and color reflectance indicate the Fe oxide-bearing, nonbioturbated foraminifer nannofossil boundary layer. The interpolated bases of planktonic foraminifer zones are indicated by arrows, sample density by black squares. Records all at the same scale.
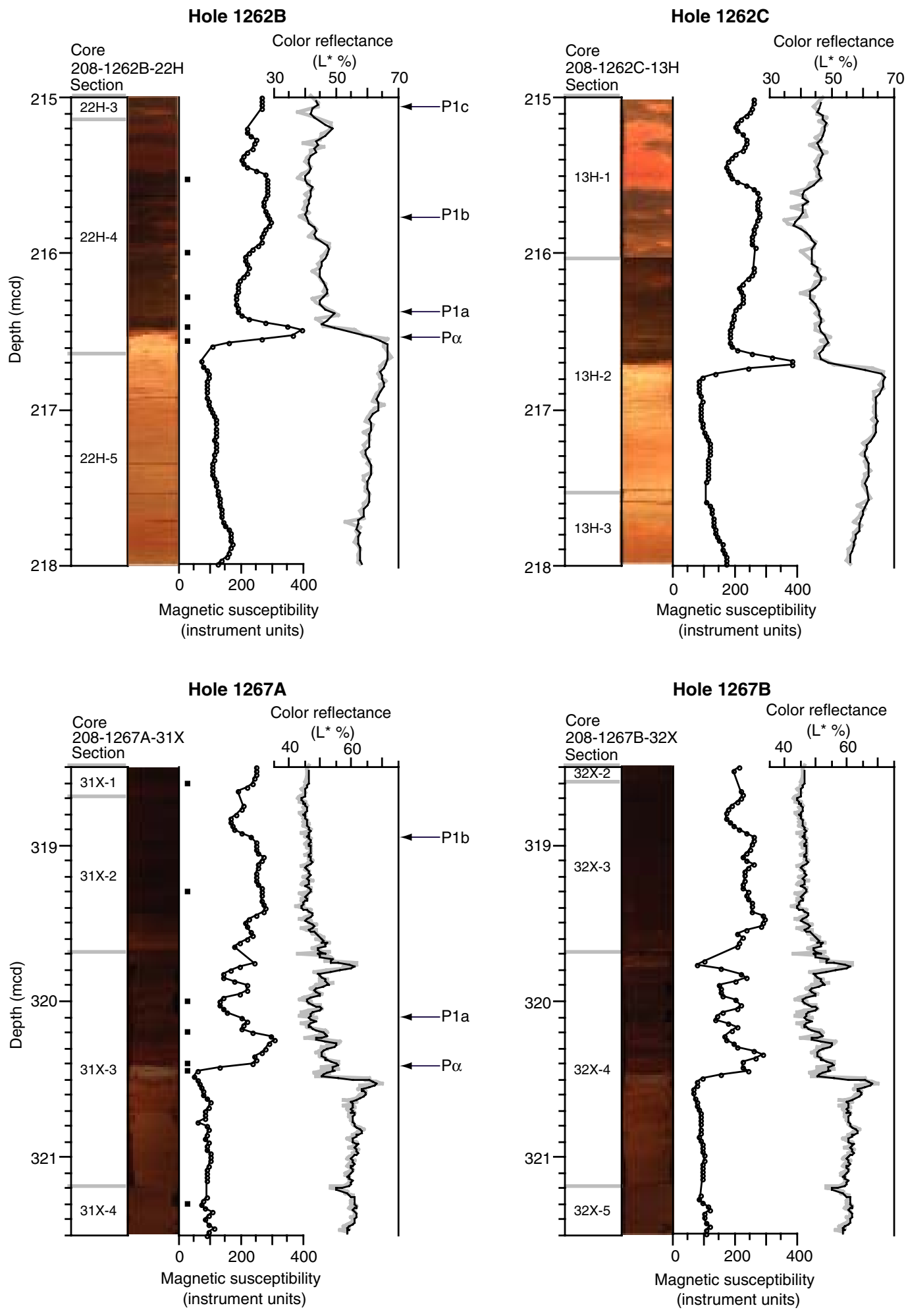


\section{KROON ET AL.}

Figure F10. Residue in the $>63-\mu \mathrm{m}$ fraction shows rapid increase at the Cretaceous/Paleogene $(\mathrm{K} / \mathrm{Pg})$ boundary indicating improvement of planktonic foraminiferal preservation. This implies rapid deepening of the CCD at the K/Pg boundary. The carbonate content record shows that precessional cycles are replaced by eccentricity cycles in the early Paleogene. VPDB = Vienna Peedee belemnite.

$\delta^{13} \mathrm{C}(\% \circ \mathrm{VPDB})$
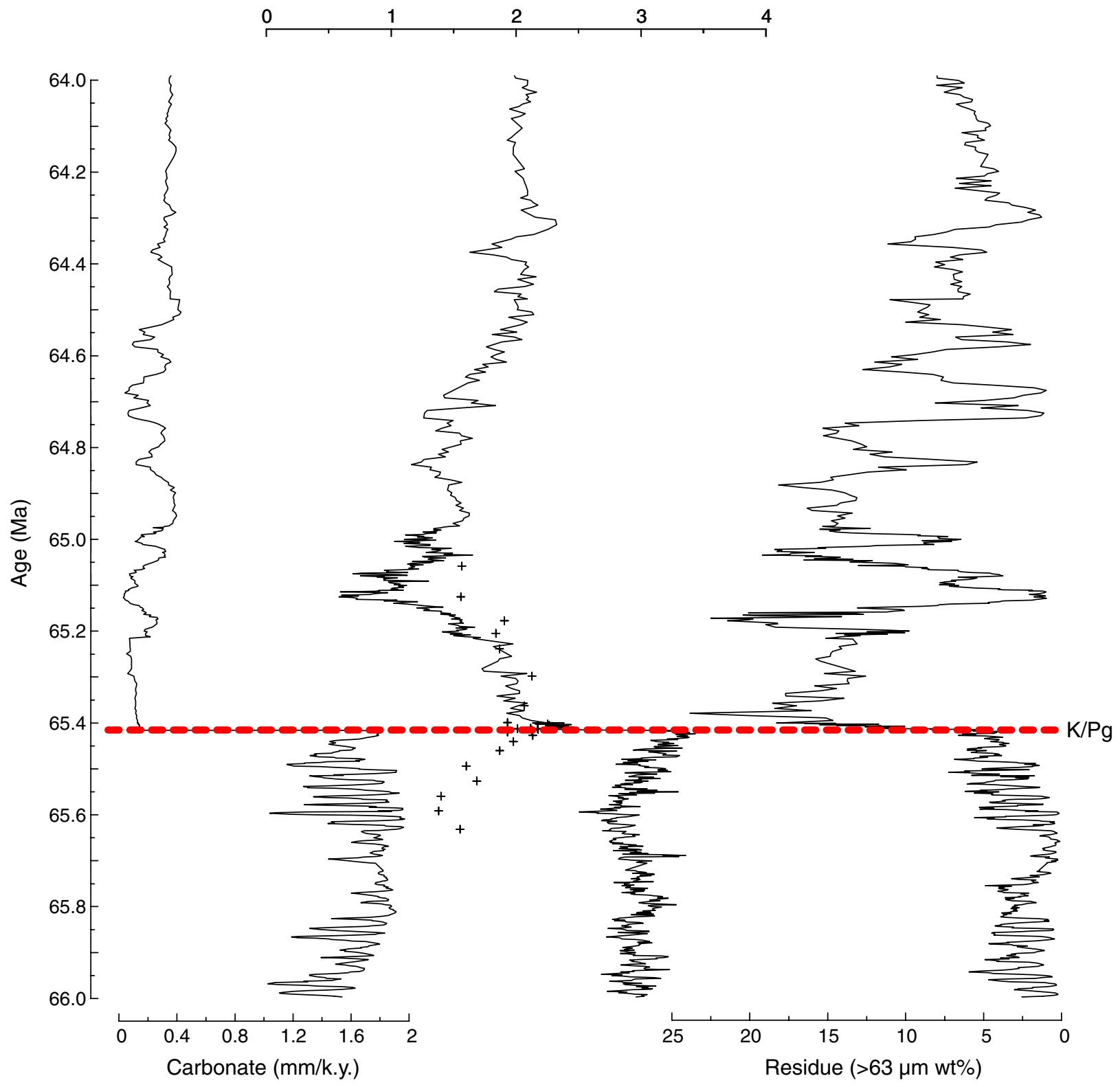


\section{KROON ET AL.}

Figure F11. Stable isotope records of bulk carbonate across the Cretaceous/Paleogene (K/Pg) boundary. The $\delta^{18} \mathrm{O}$ record shows pronounced cooling above the K/Pg boundary, whereas the $\delta^{13} \mathrm{C}$ record shows abrupt decline at the K/Pg boundary, which progressively changes to gradual decline. VPDB = Vienna Peedee belemnite.

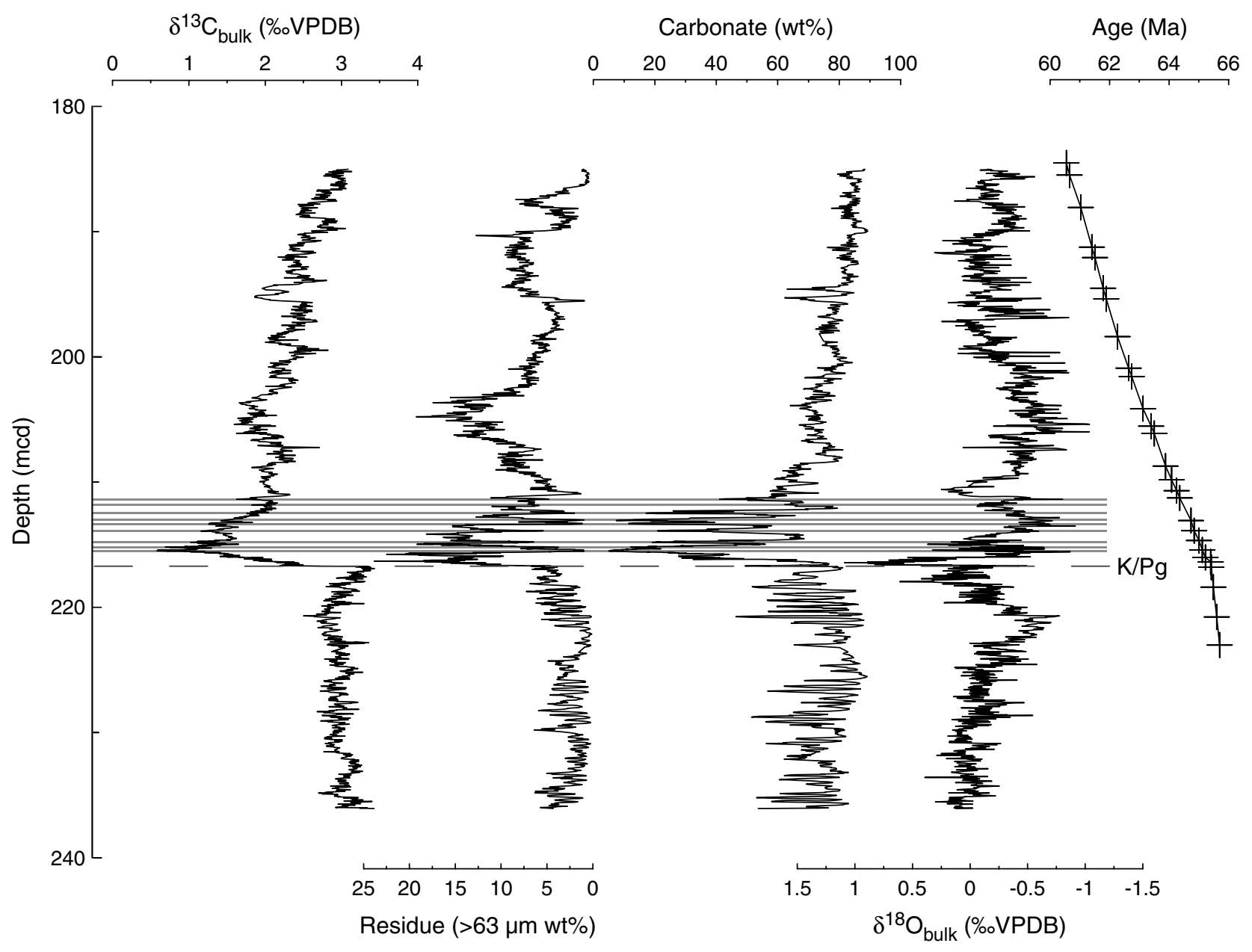


D. KROON ET AL.

Leg 208 Synthesis: Cenozoic Chimate Cycles And Excursions

Figure F12. Calculated sedimentation and carbonate accumulation rates. Orbital cycle counting produced an age model that was anchored at the K/Pg boundary. Note the large drop in accumulation of carbonate at the K/Pg boundary ( 65 Ma). The age model is based on orbital cycles (Westerhold et al., submitted [N1]).

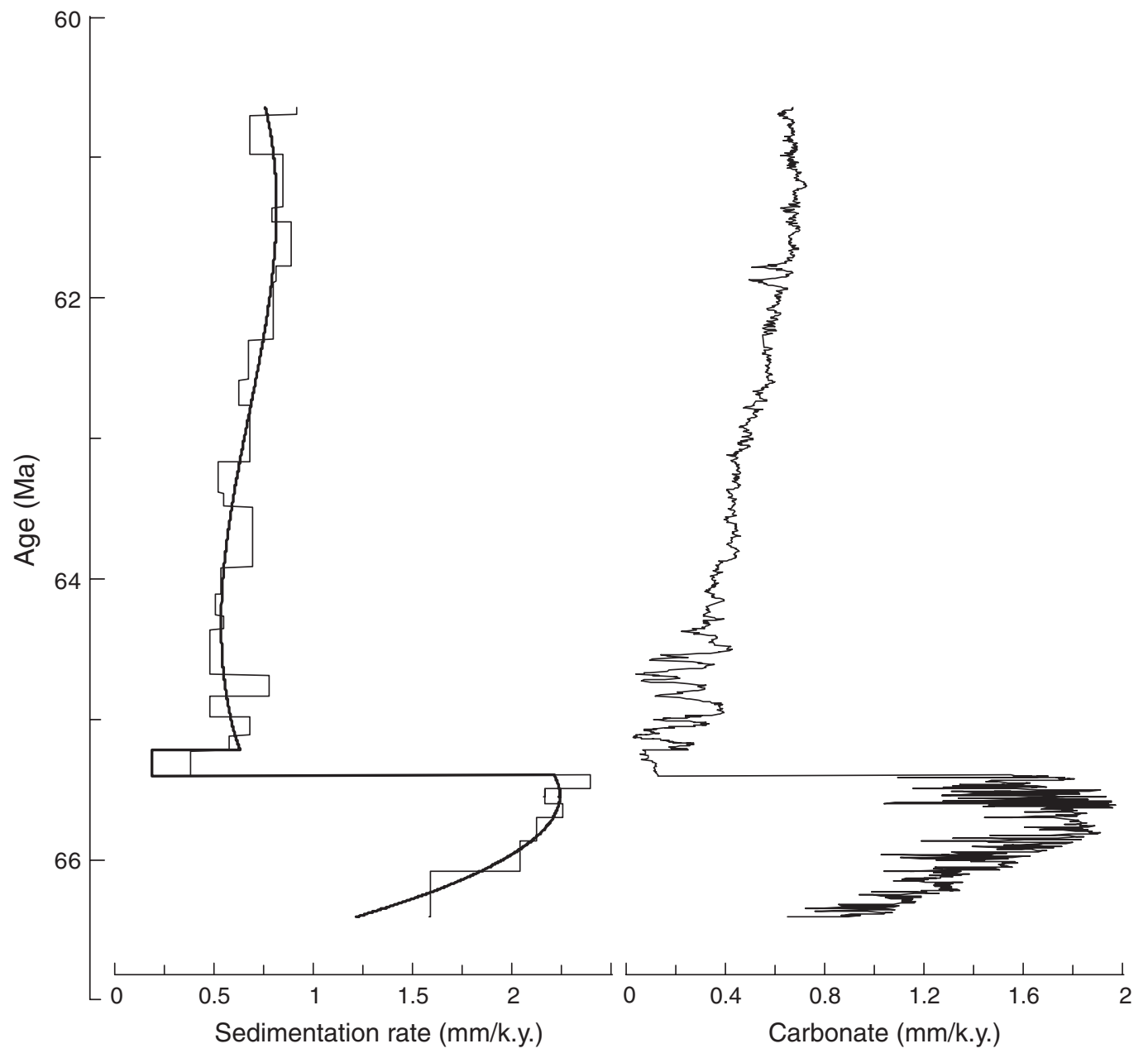




\section{KROON ET AL.}

Figure F13. Digital core photos and $\mathrm{CaCO}_{3}$ content plotted vs. depth across the $\mathrm{P} / \mathrm{E}$ boundary interval in Holes 1262A, 1263C/1263D, 1265A, 1266C, and 1267B on Walvis Ridge (Zachos, Kroon, Blum et al., 2004; Zachos et al., 2005). Records are plotted from left to right in order of increasing water depth. The core photos for each site represent composites of the following sections: 208-1262A-13H-5 and 13H-6; 208-1263C$14 \mathrm{H}-1$ and $14 \mathrm{H}-\mathrm{CC}$; 208-1263D-4H-1 and 4H-2; 208-1265A-29H-6 and 28H-7; 208-1266C-17H-2, 17H-3, and $17 \mathrm{H}-44$; and 208-1267B-23H-1, 23H-2, and 23H-3. BF-1 = last occurrence (LO) of Paleocene benthic foraminifer assemblage. BF-2 and BF-3 = first occurrence (FO) and LO, respectively, of lowermost Eocene, low-diversity, diminutive benthic foraminifer assemblage. BF- $4=$ FO of early Eocene moderate diversity benthic foraminifer assemblage.

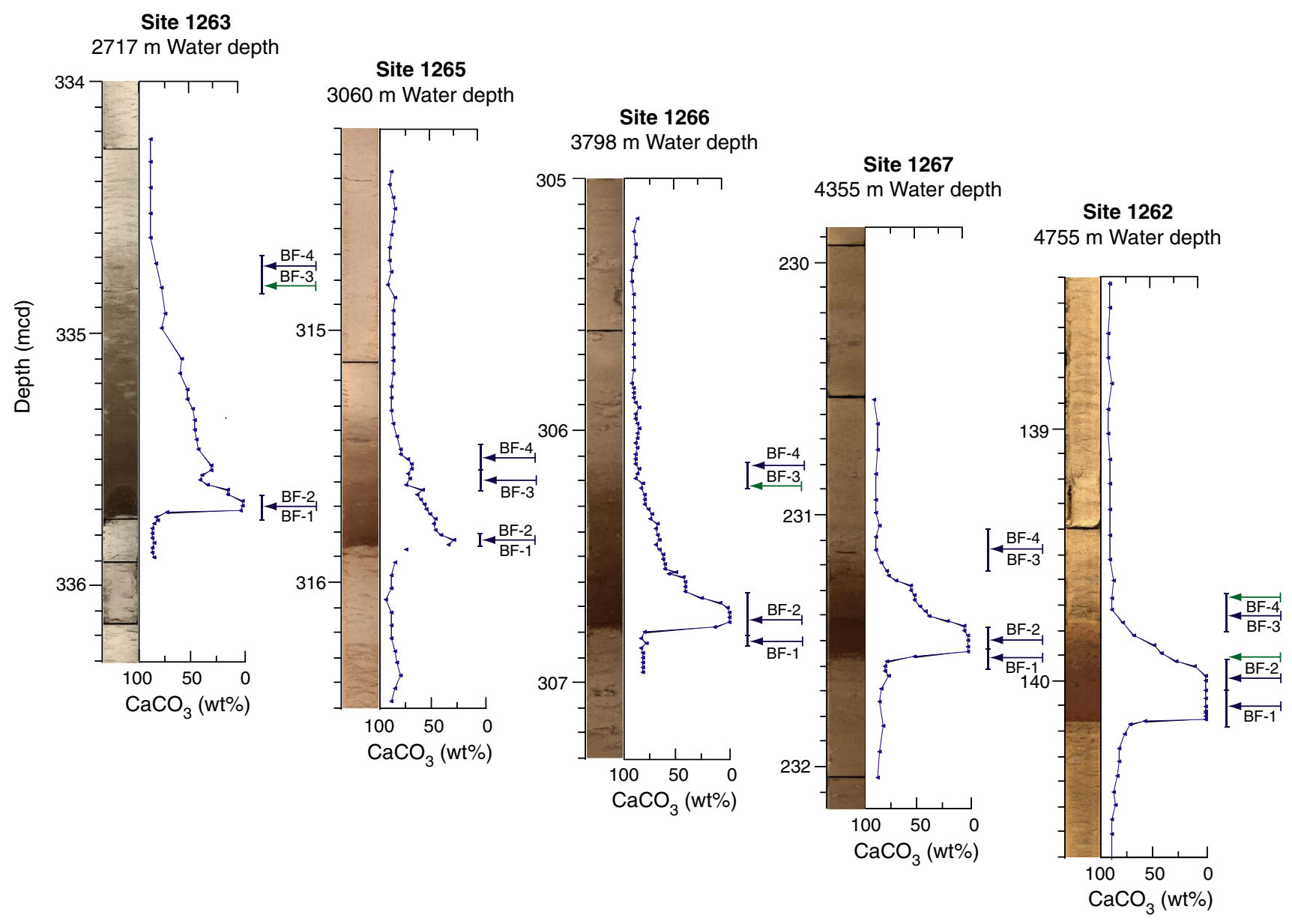


Figure F14. Bulk sediment carbon isotope records for Holes 1262A, 1263C/1263D, 1265A, 1266C, and 1267B (Zachos et al., 2005). Also plotted are nannofossil horizons (N1-N4) for Holes 1262B and 1263C/1263D. Data for ODP Site 690 (Bains et al., 1999) are plotted to the far left. Lines of correlation are based on inflections in the carbon isotope (A-G above the benthic foraminifer extinction horizon, $-\mathrm{A}$ below), Fe/Ca, and magnetic susceptibility records. VPDB = Vienna Peedee belemnite.

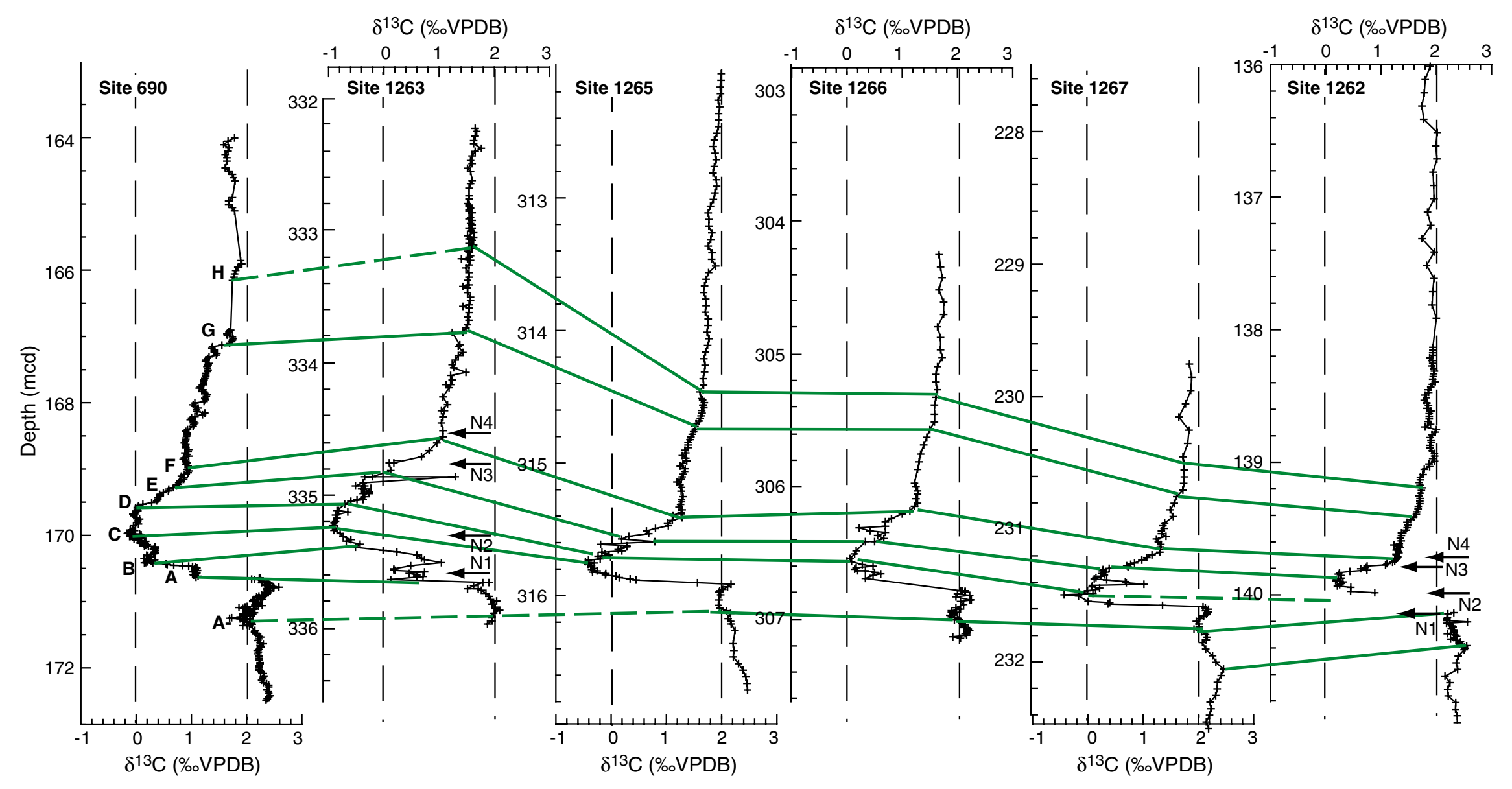


D. KROON ET AL.

Leg 208 Synthesis: Cenozoic Chimate Cycles And Excursions

Figure F15. $n$-alkane $\delta^{13} \mathrm{C}$ (Hasegawa et al., this volume) and bulk carbonate isotope values (Zachos et al., 2005). VPDB = Vienna Peedee belemnite. The arrow at 340 mcd shows the level of the benthic foraminifer extinction horizon.

A

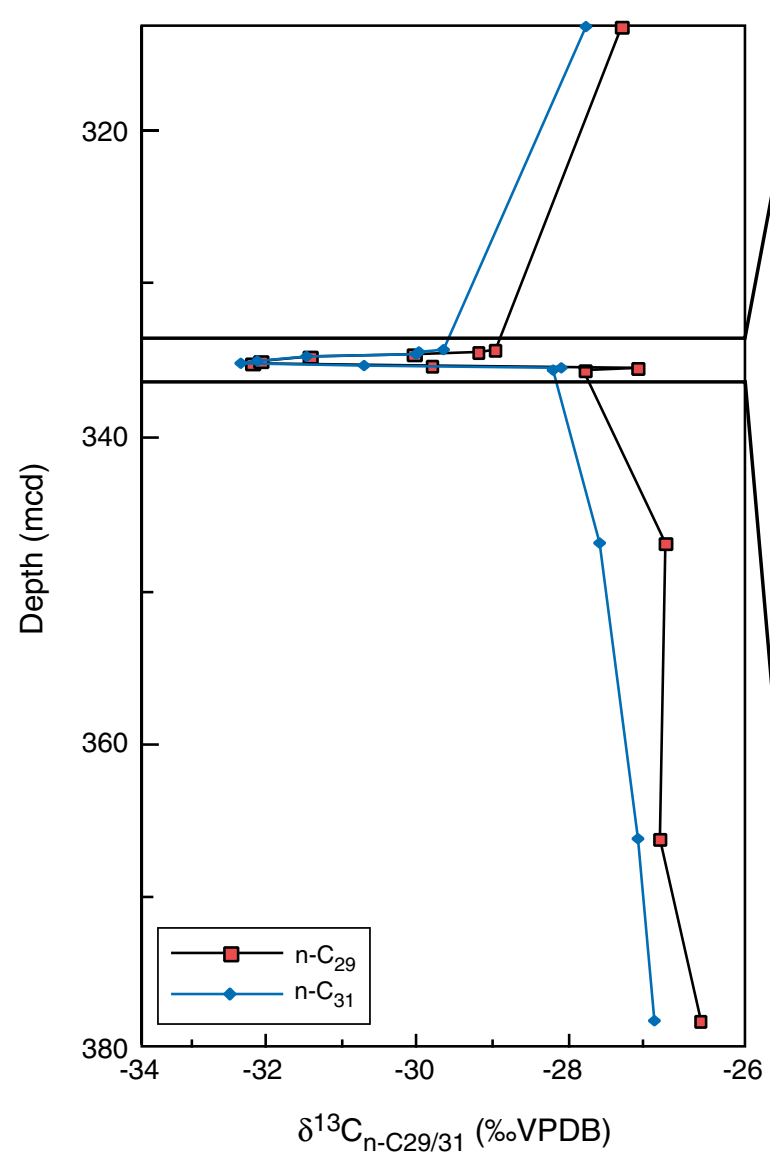

B $\quad \delta^{13} \mathrm{C}_{\text {carb }}(\% \mathrm{VPDB})$

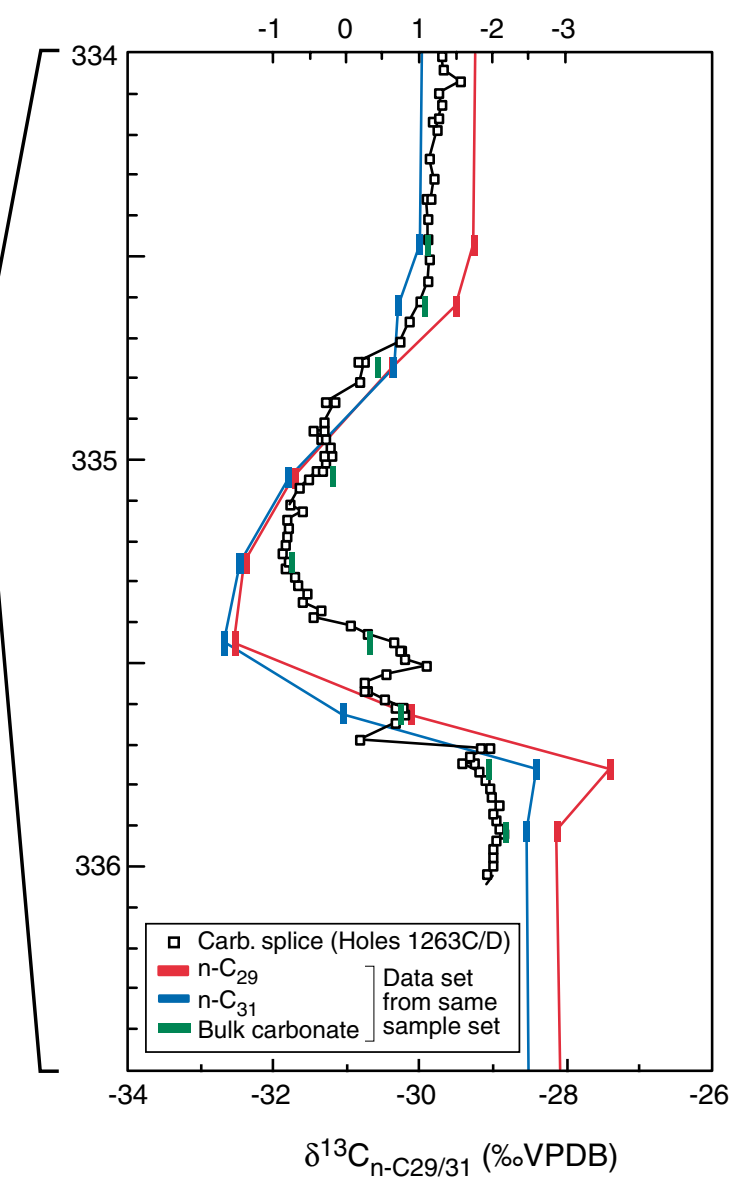




\section{KROON ET AL.}

Figure F16. Summary of Biohorizons N1-N5 at Site 1263 (Raffi et al., unpubl. data). VPDB = Vienna Peedee belemnite. $N=$ number of nannofossils.

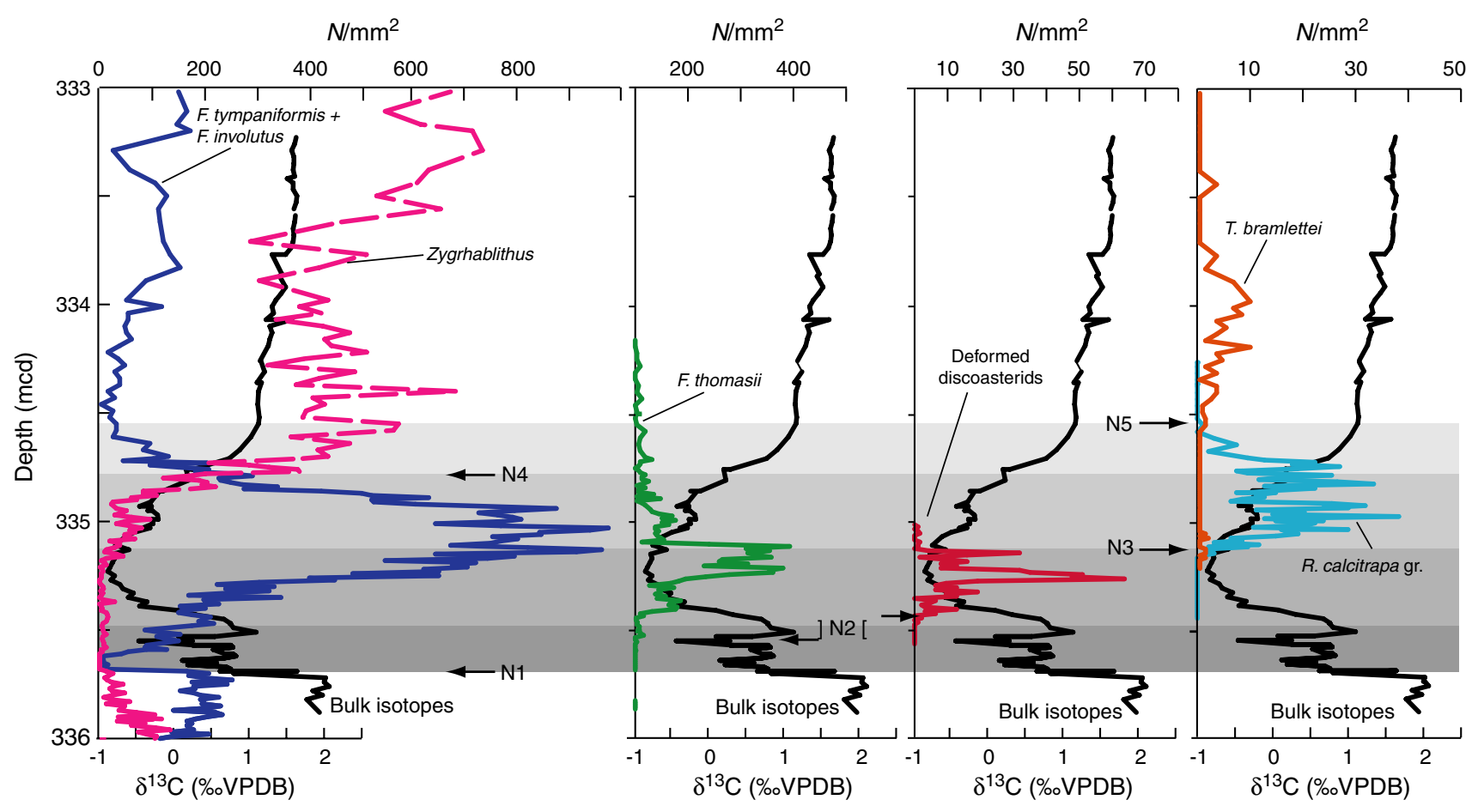




\section{KROON ET AL.}

Figure F17. Site 1263 and 1267 grain-size distributions. Five sets of time-coincident (less than 16 k.y. difference) grain-size distributions are illustrated, such that each pane (A-E) contains one distribution from the shallower Site 1263 and one distribution from the deeper Site 1267. All distributions are plotted on identical axes. Eolian percent calculated after the two-component mixing model of Boven and Rea (1998).
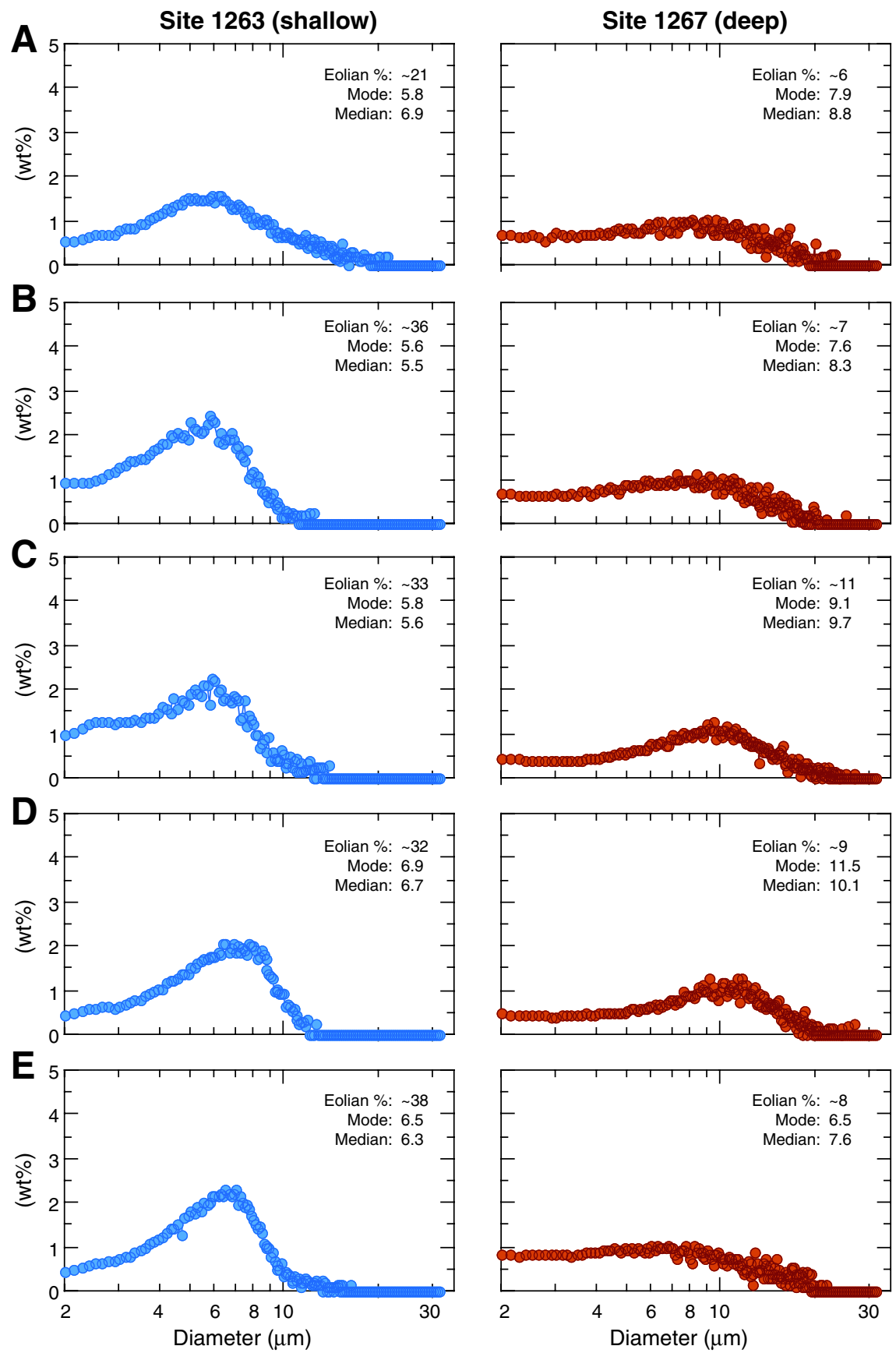
D. KROON ET AL.

Leg 208 Synthesis: Cenozoic Chimate CyCles ANd Excursions

Figure F18. Bulk carbonate $\delta^{13} \mathrm{C}$ and magnetic susceptibility (MS) records across the Elmo horizon at five Leg 208 sites (Lourens et al., 2005).
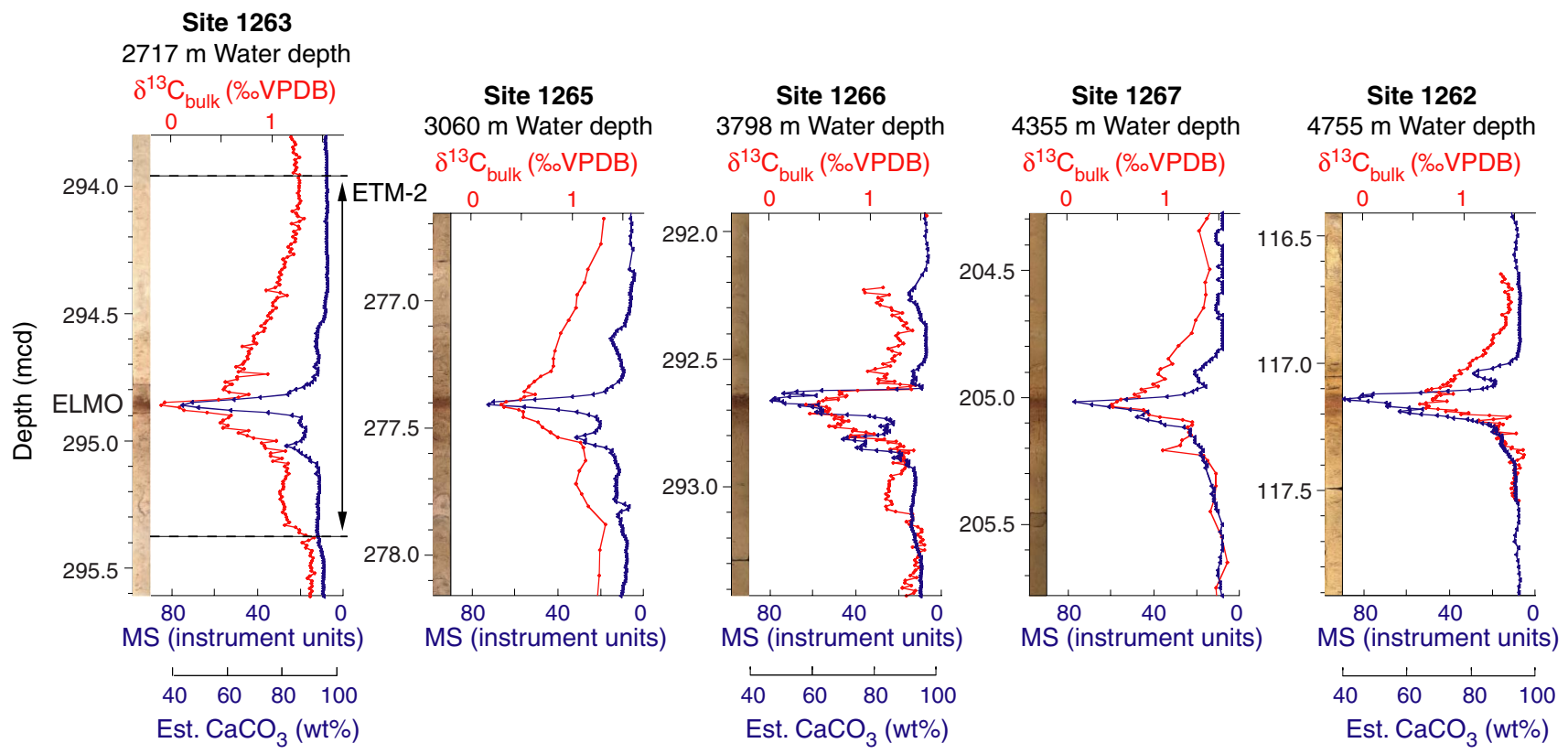


\section{KROON ET AL.}

Figure F19. Stable isotope series of the bulk sediment and single foraminifer specimens across the Elmo horizon at Site 1263 (Lourens et al., 2005). A. $\delta^{13} \mathrm{C}$ values (blue dots) of the surface-dwelling planktonic foraminifer Acarinina soldadoensis (A.sold). B. $\delta^{13} \mathrm{C}$ values of the surface-dwelling benthic foraminifers Cibicidoides spp. (red squares) and Anomalinoides spp. (green dots). C. As in A but for $\delta^{18} \mathrm{O}$. D. As in B but for $\delta^{18} \mathrm{O}$. Light gray lines in $\mathrm{A}$ and $\mathrm{B}$, and $\mathrm{C}$ and $\mathrm{D}$ indicate, respectively, the $\delta^{13} \mathrm{C}$ and $\delta^{18} \mathrm{O}$ values of the bulk sediment. Darker lines represent three-point moving averages on averaged values of duplicate analyses of a sample. Isotope values of the two benthic taxa are not significantly different and are both used for the latter curves.

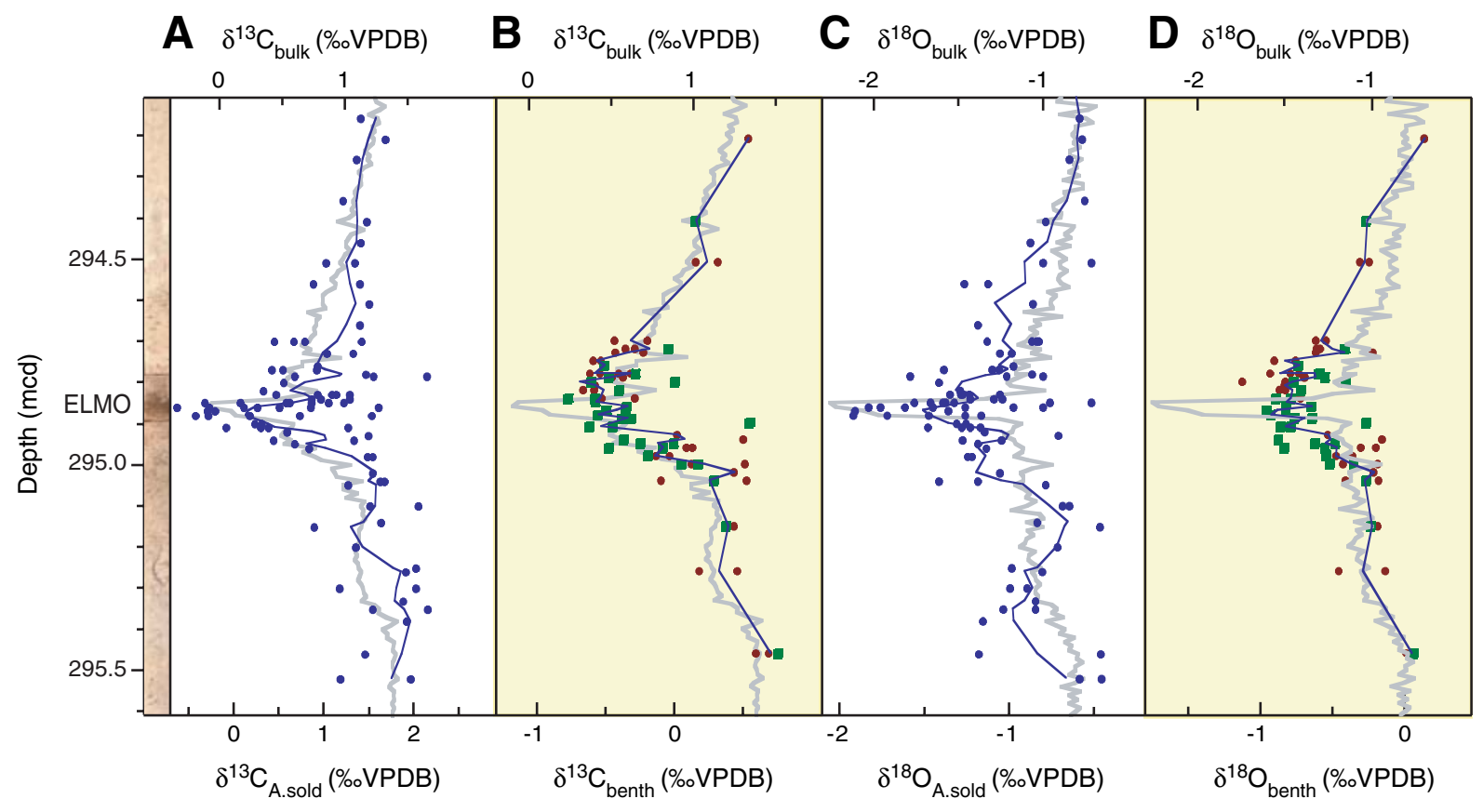




\section{KROON ET AL.}

Figure F20. Stable oxygen and carbon isotope records of benthic foraminifer Cibicidoides mundulus (C.mund) for Sites 1263, 1265, and 1266, and of bulk fragments of planktonic foraminifer fragments (PF.frag.) for Site 1262 plotted as a function of age for the period 30-35 Ma. The carbonate fossils of Site 1262 were completely dissolved below the Eocene/Oligocene boundary at 33.7 Ma (Liu et al., 2004b). The earliest Oligocene Glacial Maximum (EOGM) spans the interval 33.2-33.6 Ma for all sites. The age model is based on the onboard calcareous nannofossil and foraminifer stratigraphies combined with the magnetic stratigraphy (Zachos, Kroon, Blum, et al., 2004). VPDB = Vienna Peedee belemnite.

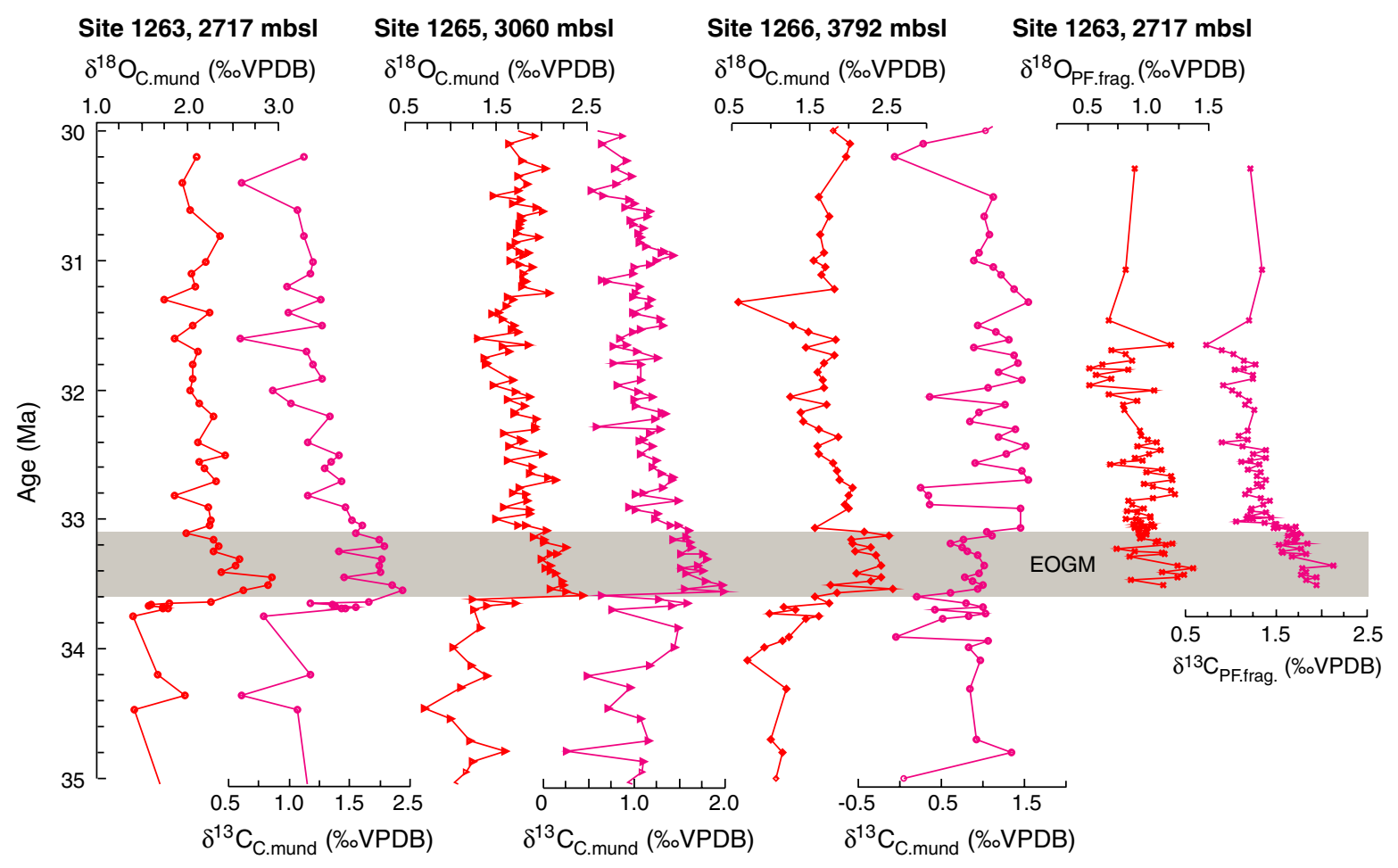




\section{KROON ET AL.}

Figure F21. Carbonate content and coarse fraction variations for Sites 1263, 1265, 1266, and 1262, and color reflectance $L^{*}$ variation for Site 1267 for the period 30-35 Ma. The abrupt increase in carbonate content associated with the strongest foraminifer dissolution above the Eocene/Oligocene boundary leads the earliest Oligocene Glacial Maximum (EOGM) by 100 k.y., while the recovery of the foraminiferal preservation lags behind the EOGM by 400 k.y. (Liu et al., 2004a). Data of the color reflectance $\mathrm{L}^{*}$ are from the onboard data set (Zachos, Kroon, Blum, et al., 2004).

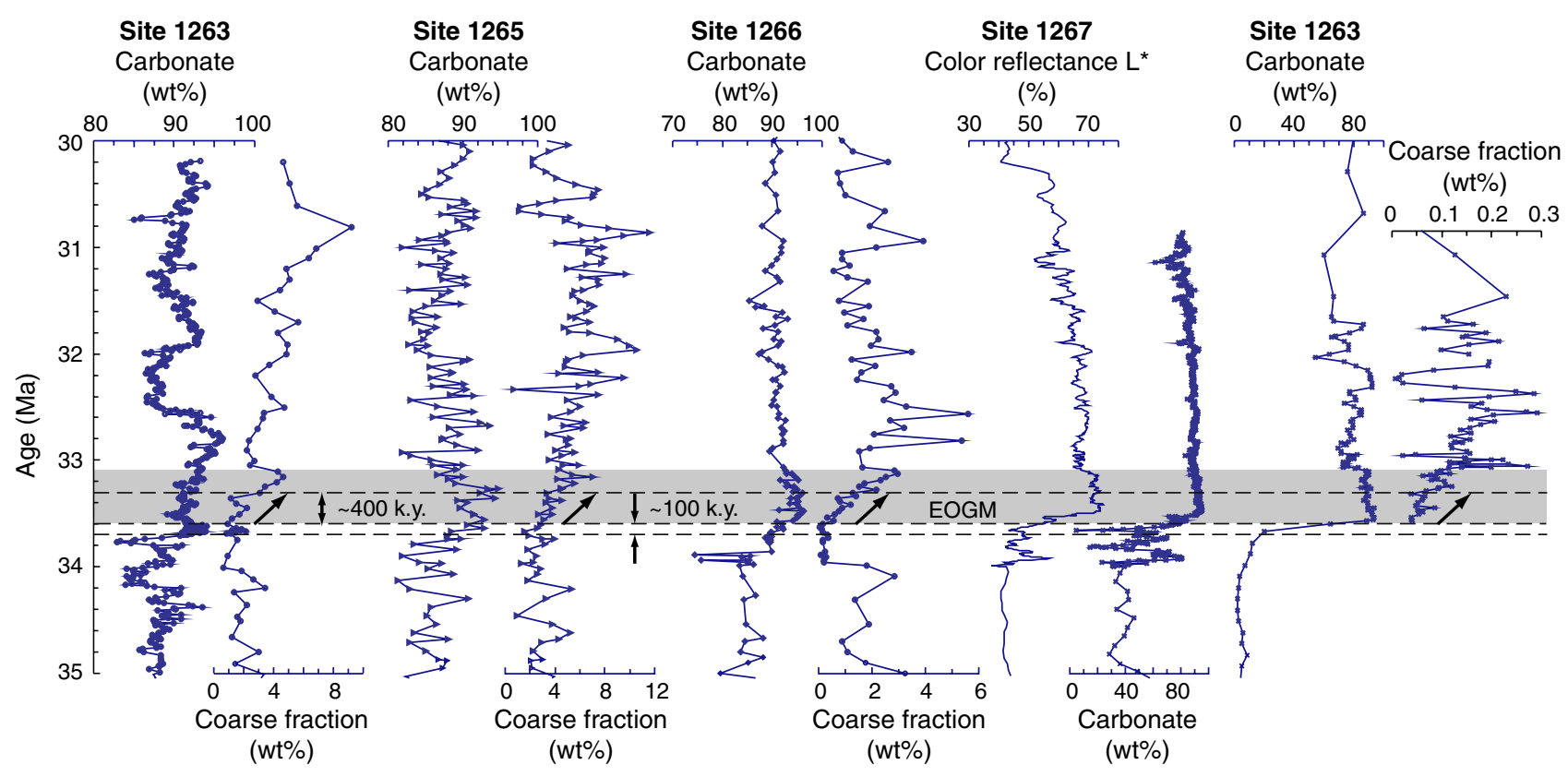


D. KROON ET AL.

Leg 208 Synthesis: Cenozoic Chimate Cycles And Excursions

Figure F22. Leg $208 \mathrm{Nd}$ isotope record. Values are expressed using epsilon notation and corrected for age. Error bars represent within-run precision (Via and Thomas, 2006).

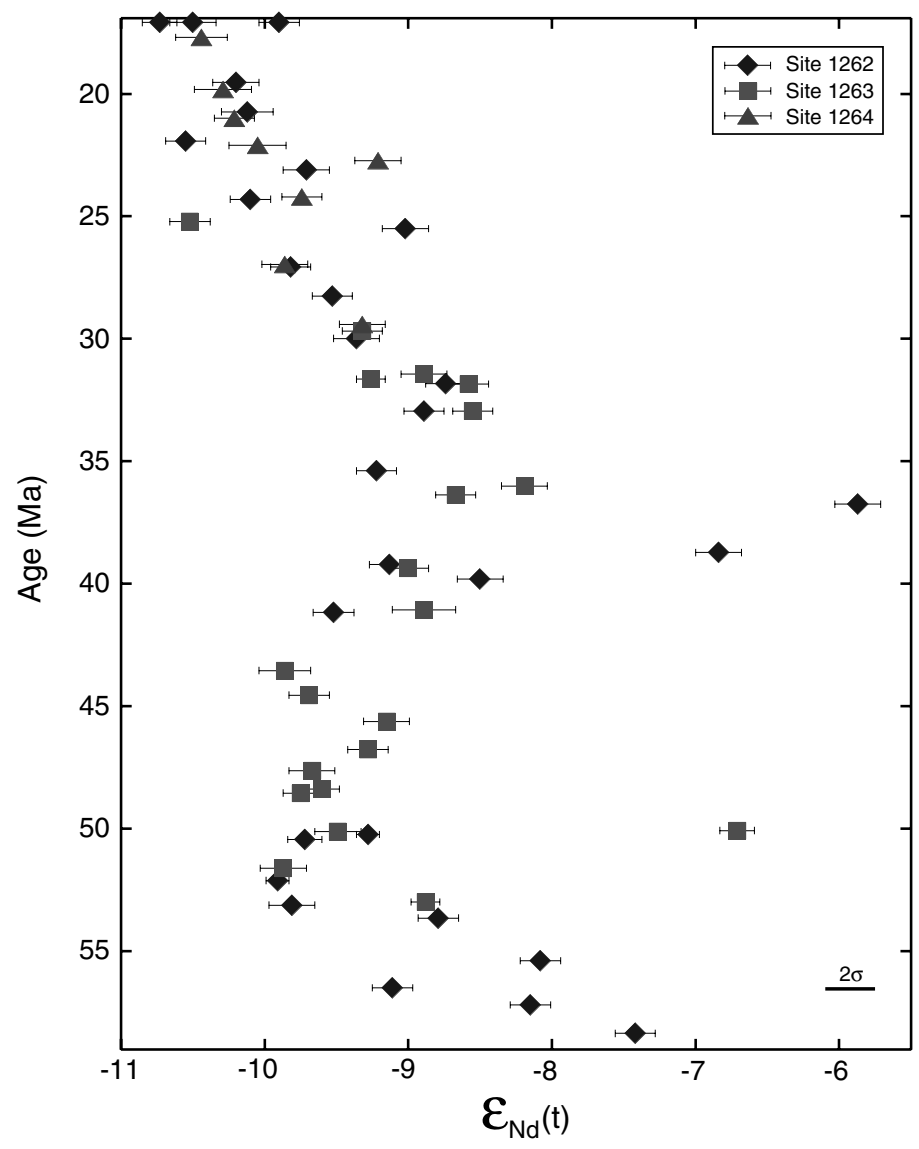




\section{KROON ET AL.}

Figure F23. Strontium isotope results from Leg 208 sites. Records are arranged stratigraphically with the events taken as the splice tie points indicated by arrows (Hodell et al., submitted [N4]). PETM = Paleocene/ Eocene Thermal Maximum. $\mathrm{K} / \mathrm{Pg}=$ Cretaceous/Paleogene boundary.

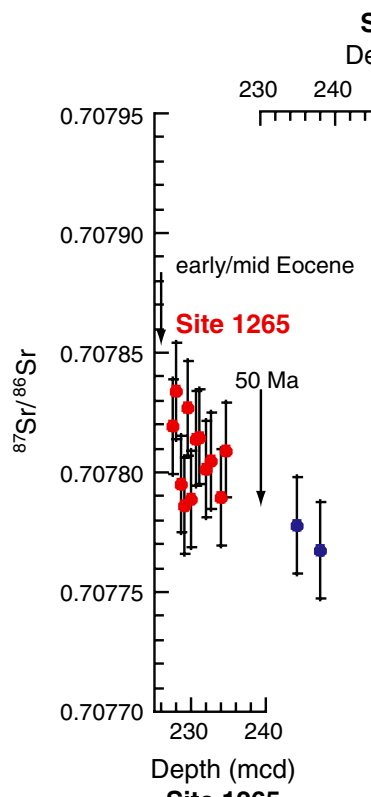

Site 1265
Site 1263

Depth $(\mathrm{mcd})$

$250 \quad 260 \quad 270$
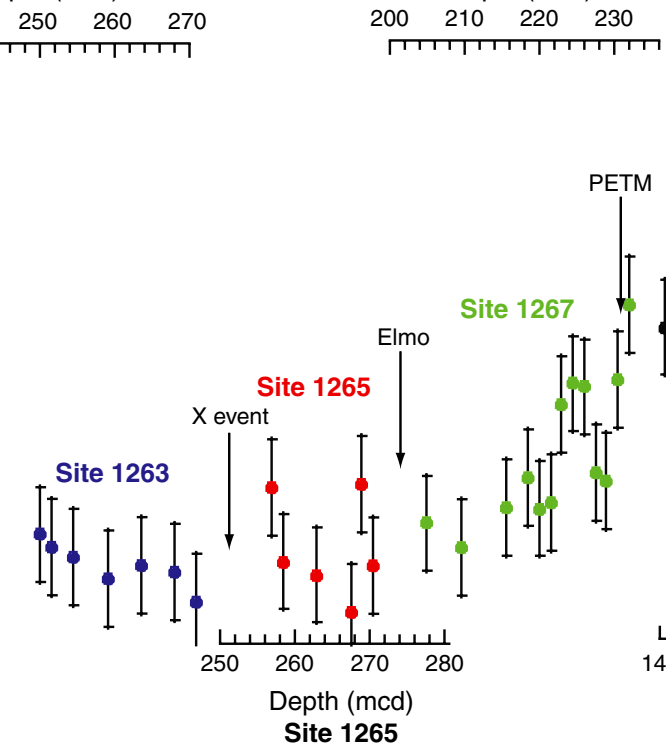

Site 1265
Site 1267

Depth (mcd) 
D. KROON ET AL.

Leg 208 Synthesis: Cenozoic Chimate Cycles And Excursions

Figure F24. Temporal record of (A) foraminiferal $\delta^{7} \mathrm{Li}$, (B) foraminiferal $\mathrm{Li} / \mathrm{Ca}$, and $(\mathbf{C})$ foraminiferal $\mathrm{Li} / \mathrm{Ca}$ corrected for species effects (Hathorne and James, 2006). Atlantic data are from Leg 208 Site 1264. Solid lines show the least-squares fit to the data, such that $R^{2}>0.8$.
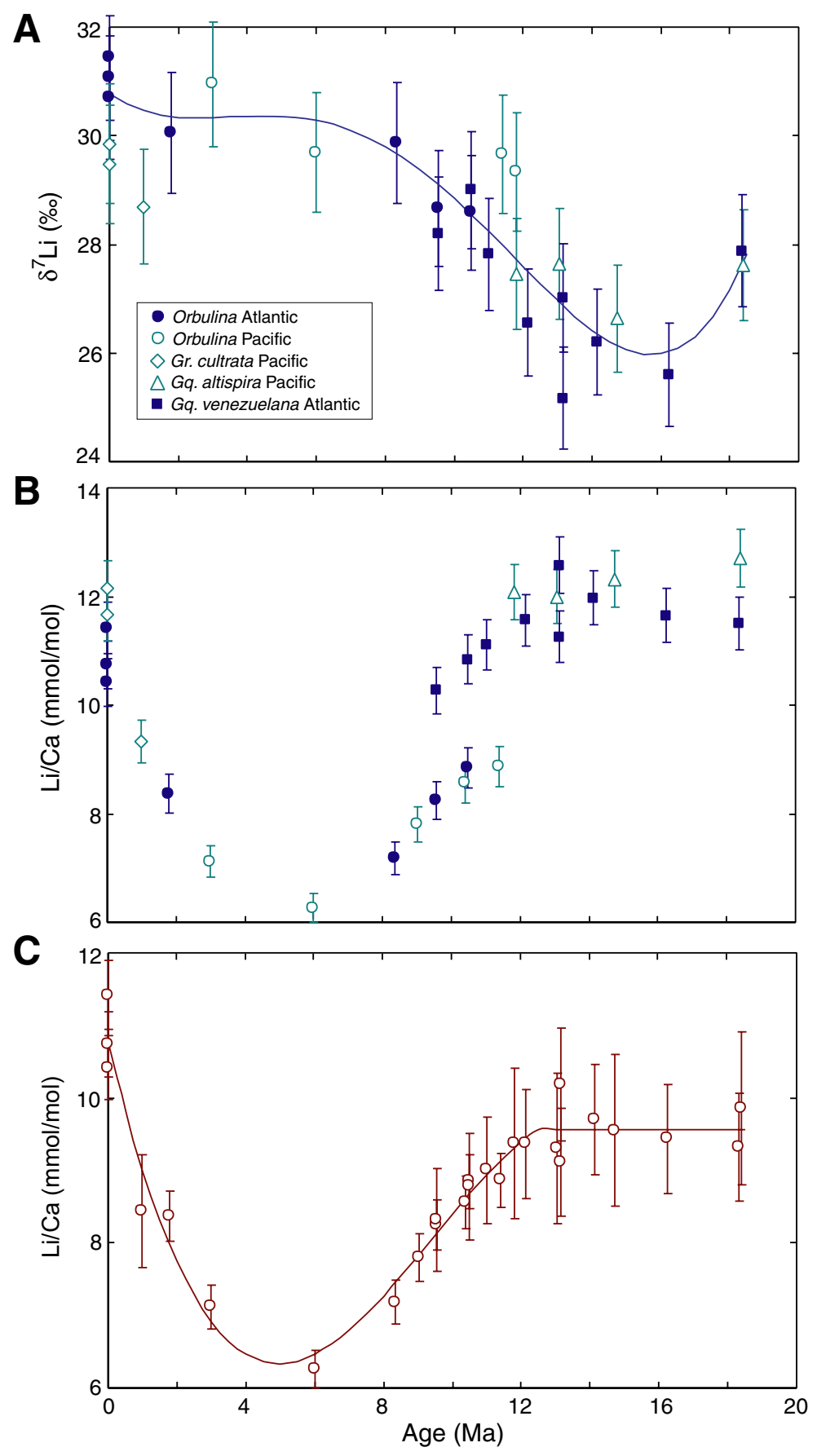


\section{CHAPTER NOTES*}

N1. Westerhold, T., Röhl, U., Raffi, I., Fornaciari, E., Monechi, S., Reale, V., Bowles, J., and Evans, H.F., submitted. The first comprehensive orbital chronology for the Paleocene: implications for the geomagnetic polarity time scale and the age of the K/Pg boundary. Palaeogeogr., Palaeoclimatol., Palaeoecol.

N2. Röhl, U., Westerhold, T., Bralower, T.J., and Zachos, J.C., submitted. Status of the duration of the Paleocene-Eocene Thermal Maximum (PETM). Geochem., Geophys., Geosyst.

N3. Agnini, C., Fornaciari, E., Raffi, I., Rio, D., Röhl, U., and Westerhold, T., submitted. Middle Paleocene to early Eocene calcareous nannoplankton biostratigraphy, biochronology and mode of evolution: inferences from ODP Site 1262, Walvis Ridge. Mar. Micropaleontol.

N4. Hodell, D.A., Kamenov, G.D., Hathorne, E.C., Zachos, J.C., Rohl, U., and Westerhold, T., submitted. Strontium isotope composition of seawater during the Paleocene and Eocene: implications for volcanic activity, atmospheric $\mathrm{CO}_{2}$ and climate. Earth Planet. Sci. Lett. 